\title{
STOCK RETURN VOLATILITY, FIRM REAL OPTION VALUE, AND MERGERS AND ACQUISITIONS PREMIUMS
}

\author{
By \\ Uyen (Wendy) Nguyen \\ A thesis presented to Ryerson University \\ in partial fulfillment of the \\ requirements for the degree of \\ Master of Science in Management (MScM) \\ in the program of Master of Science in Management
}

Toronto, Ontario, Canada, 2018

Uyen (Wendy) Nguyen, 2018 


\section{AUTHOR'S DECLARATION FOR ELECTRONIC SUBMISSION OF A THESIS}

I hereby declare that I am the sole author of this thesis. This is a true copy of the thesis, including any required final revisions, as accepted by my examiners. I authorize Ryerson University to lend this thesis to other institutions or individuals for the purpose of scholarly research. I further authorize Ryerson University to reproduce this thesis by photocopying or by other means, in total or in part, at the request of other institutions or individuals for the purpose of scholarly research. I understand that my thesis may be made electronically available to the public. 


\title{
STOCK RETURN VOLATILITY, FIRM REAL OPTION VALUE, AND MERGERS AND ACQUISITIONS PREMIUMS
}

\author{
Uyen (Wendy) Nguyen \\ Master of Science in Management (MScM) \\ Ted Rogers School of Management \\ Ryerson University
}

2018

\begin{abstract}
Considerable effort has been devoted to indicate the critical determinants of acquisition premiums. However, the determinants of mergers and acquisitions (M\&A) premiums are not yet fully understood. This research paper empirically examines the effect of stock return volatility on mergers and acquisitions premiums through real options value of bidder and target firms. With a sample of 2,559 completed M\&A deals in the US during 1986-2016, we find that bidder firms tend to pay more premiums for the targets that have more future real option value and higher risk. To be more specific, when targets have more real options measured as high Research and Development (R\&D) to market value, high sales growth rate, and low leverage ratio, the relationship between target return volatility and acquisition premiums is stronger. This study contributes not only to the literature regarding the determinants of mergers and acquisitions premiums but also to the literature of real options value.
\end{abstract}

Keywords: Mergers and acquisition premiums, acquisition premiums, stock return volatility, real options, growth options 


\section{ACKNOWLEDGEMENTS}

This thesis has significantly benefited from the support of many people, some of whom I would sincerely like to thank here.

Firstly, it is with sincere gratitude and appreciation that I acknowledge the professional guidance of Dr. Yuanshun Li. His constant support, advice, and encouragement helped me to archive my goal.

Secondly, I am grateful to Dr. Melissa Toffanin for her comments and suggestions to improve my thesis structure.

Thirdly, I would like to express my sincere thank you to my professors at Ted Rogers School of Management, Ryerson University for teaching and training me during the one-year period. The knowledge and skills I have learned help me so much during the thesis semester.

Finally, from the bottom of my heart, I would like to thank my parents for their unconditional support not only on the financial aspect but also on their love and respect. The broad education that I was able to enjoy while growing up has proven invaluable. 


\section{TABLE OF CONTENTS}

AUTHOR'S DECLARATION FOR ELECTRONIC SUBMISSION OF A THESIS ......... ii

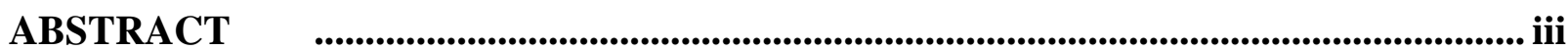

ACKNOWLEDGEMENTS .................................................................................................... iv

LIST OF TABLES ..................................................................................................................... vii

LIST OF APPENDICES ..................................................................................................... viii

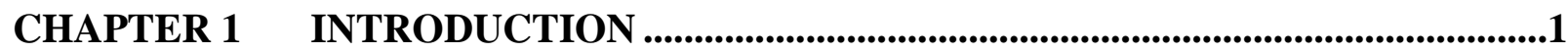

CHAPTER 2 LITERATURE REVIEWS ...............................................................................5

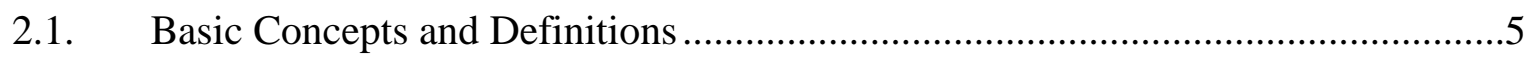

2.1.1. Mergers and Acquisitions Premium definition ..........................................................

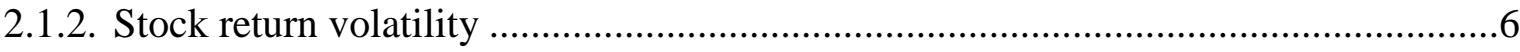

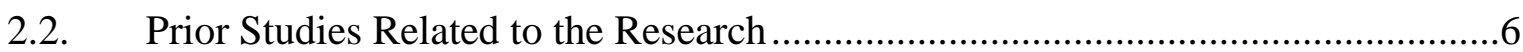

2.2.1. Positive relationship between volatility and stock return is due to real option value.6

2.2.2. The determinants of growth options ...................................................................

2.2.3. Determinants of $M \& A$ premiums based on real option based theory .........................

2.2.4. Idiosyncratic volatility and M\&A premium: ...........................................................

2.2.5. Research and Development (R\&D) Investment and M\&A premium:........................9

2.2.6. Other factors affecting mergers and acquisitions premium ......................................10

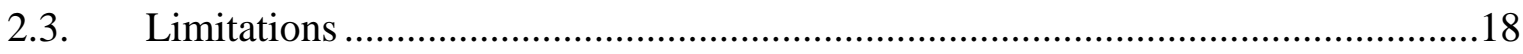

CHAPTER 3 METHODOLOGY ..........................................................................................19

3.1. Sampling, data collecting procedure ................................................................19

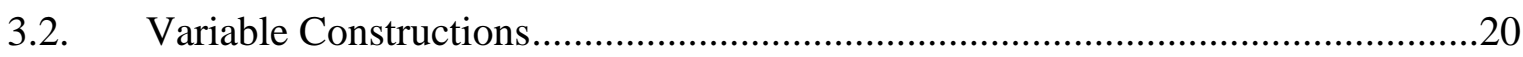

3.2.1. Independent variable: Mergers and acquisitions premium .......................................20

3.2.2. Dependent variables: Growth options variables ........................................................21

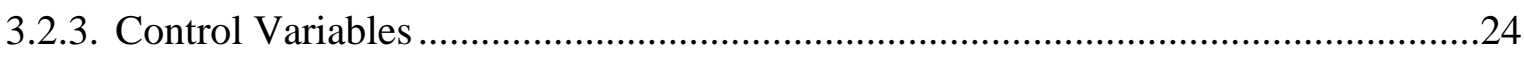

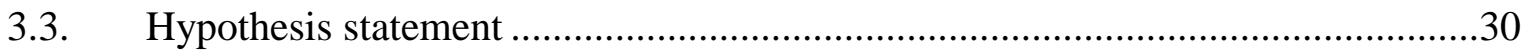

3.4. Data Analysis Methodology .............................................................................30

3.5. Limitation and Potential problems .....................................................................

CHAPTER 4 EMPIRICAL RESEARCH FINDING ...........................................................33

4.1. Descriptive Statistics.........................................................................................33 


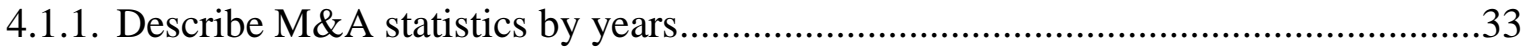

4.1.2. Summary statistics of acquisition premium and growth option variables ...............35

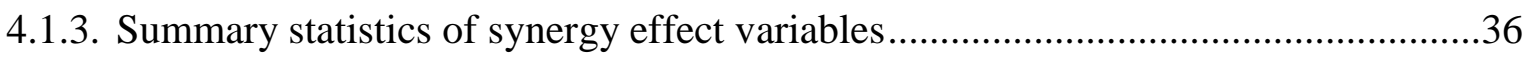

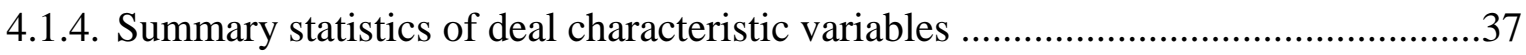

4.1.5. Summary statistics of target firm characteristic variables ....................................38

4.1.6. Summary statistics of bidder firm characteristic variables ...................................39

4.2. Check for potential problems in multiple regression models ..............................40

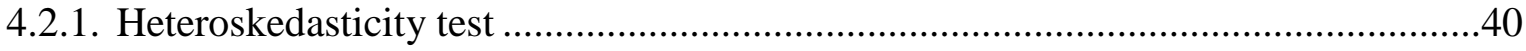

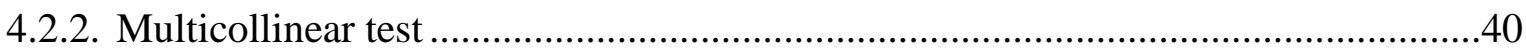

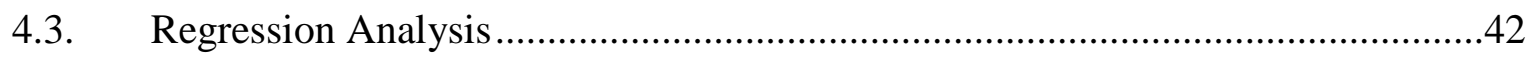

4.3.1. Regressions without interaction terms between volatility and real option variables 42

4.3.2. Regressions with interaction terms between volatility and real option variables .....55

4.3.3. Regression with two sub-sample when bidder volatility is higher than target volatility, and when bidder volatility is lower than target volatility ..........................................61

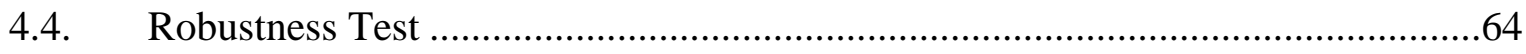

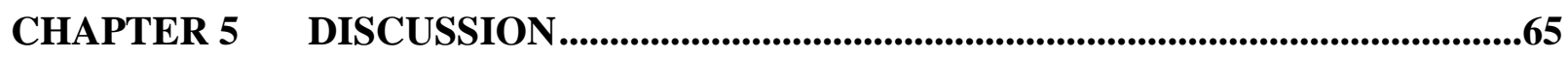

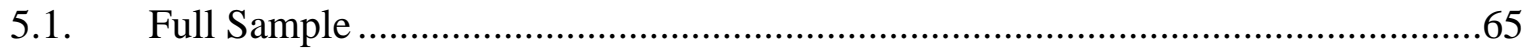

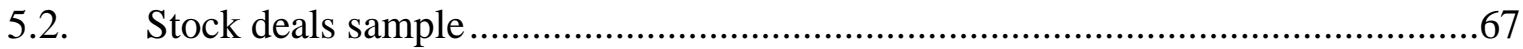

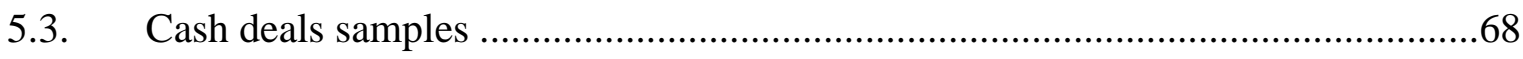

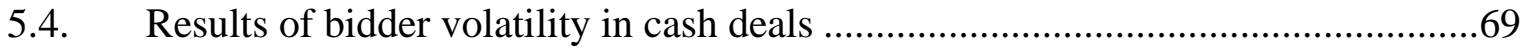

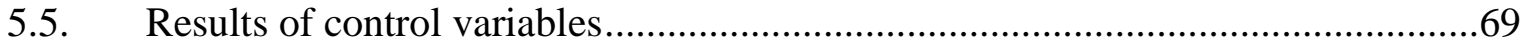

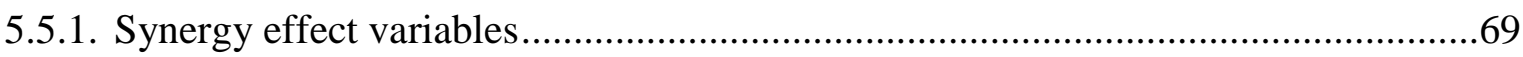

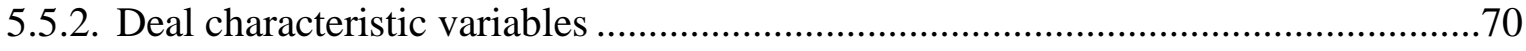

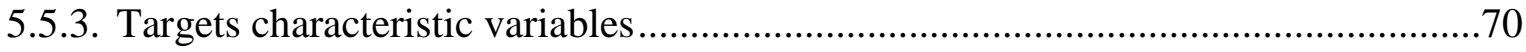

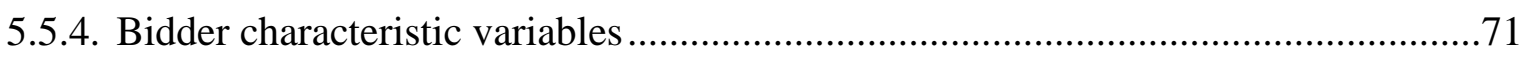

CHAPTER 6 CONCLUSION AND RECOMMENDATION ...................................72

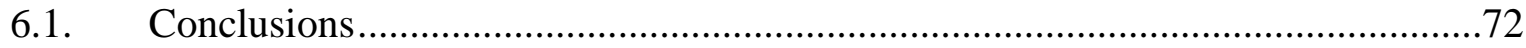

6.2. Recommendation and Proposed Further Research ........................................73

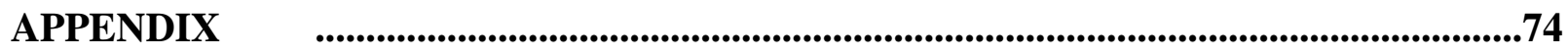

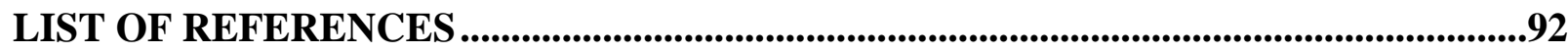




\section{LIST OF TABLES}

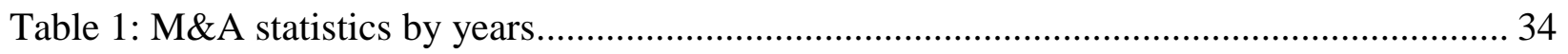

Table 2: Summary statistics of acquisition premium and growth option variables ....................... 36

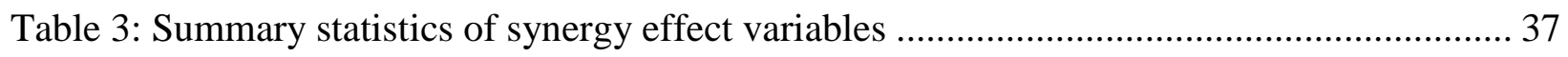

Table 4: Summary statistics of deal characteristic variables ...................................................... 38

Table 5: Summary statistics of target firm characteristic variables .............................................. 39

Table 6: Summary statistics of bidder firm characteristic variables ............................................. 39

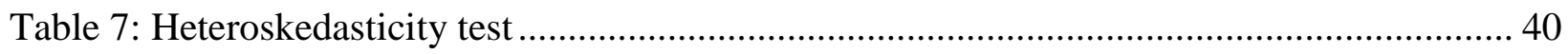

Table 8: Regression results of S\&P adjusted M\&A premiums, idiosyncratic volatility, and real

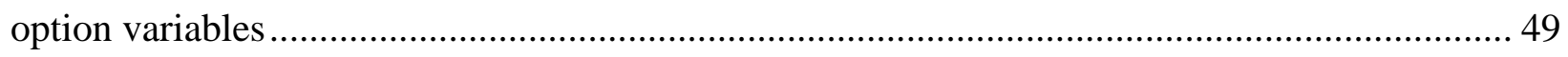

Table 9: Regression results of S\&P adjusted M\&A premiums, total volatility, and real option

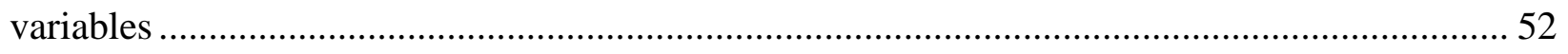

Table 10: Regression results of S\&P adjusted M\&A premiums, idiosyncratic volatility, real option variables, and interaction terms between idiosyncratic volatility and real option variables

Table 11: Regression results of S\&P adjusted M\&A premiums, total volatility, real option

variables, and interaction terms between total volatility and real option variable.

Table 12: Regressions with two sub-sample when bidder volatility is higher than target volatility, and when bidder volatility is lower than target volatility 62 


\section{LIST OF APPENDICES}

Appendix A. Variable measurement and data source

Appendix B. Regression results of M\&A premiums, idiosyncratic volatility, and real option

variables

Appendix C. Regression results of M\&A premiums, idiosyncratic volatility, real option

variables, and interaction terms between idiosyncratic volatility and real option variables 81

Appendix D. Regression results of M\&A premiums, total volatility, and real option variables .. 85

Appendix E. Regression results of M\&A premiums, total volatility, real option variables, and interaction terms between total volatility and real option variables 


\section{CHAPTER 1}

\section{INTRODUCTION}

Mergers and acquisitions (M\&A) have received considerable attention in the literature. Takeover bid premium is a significant factor to explain the returns obtained by the stockholders. Several previous research papers claim that high takeover premiums are value destroying for bidder shareholders. However, other research papers argue that large acquisition premiums lead to the high stock return. Some research papers provide the results that M\&A premium and stock return are positively correlated (Antoniou, Arbour, \& Zhao, 2008; Bradley, Desai, \& Kim, 1983; Díaz, Azofra, \& Gutiérrez, 2009; Greenfield, 1992). On the other hand, Varaiya and Ferris (1987), Sirower (1997), and Schwert (2003) find that the M\&A premiums are negatively correlated with abnormal stock return.

Although various studies are interested in understanding how M\&A premiums affect stock return, considerable effort has been devoted to identify the critical determinants of acquisition premiums. Nevertheless, the drivers of M\&A premiums are not yet fully understood. Deal characteristic factors that have been found in the literature to affect M\&A premiums include number of competing bids (Haunschild, 1994; Hayward \& Hambrick, 1997; Zhu, Jog, \& Otchere, 2014), methods of payment (Chan, Lakonishok, \& Sougiannis, 2001; Slusky \& Caves, 1991),

tender offer (Chatterjee, John, \& Yan, 2012; Jindra \& Moeller, 2015; Zhu et al., 2014), and deal size (Chan et al., 2001). Additionally, some studies find that the high premium that the bidder paid when they take over another company is consistent with the synergy between bidders and targets (Chatterjee et al., 2012; Hayward \& Hambrick, 1997; Sudarsanam \& Sorwar, 2010; Zhu et al., 2014). Moreover, target resistance to takeover has been found to be positively correlated with M\&A premiums (Baron, 1983; Laamanen, 2007; Sinha, 1992). Also, Laamanen (2007) find the 
positive effect between R\&D intensity of target firm and M\&A premium. Chatterjee et al. (2012) and Zhu et al. (2014) find a positive relationship between acquisition premiums and idiosyncratic volatility. Chatterjee et al. (2012) and Zhu et al. (2014) use asymmetric information theory and the diversity of investor opinion to explain the results. No previous research papers investigate the effects of stock return volatility on M\&A premiums through real option values contained in the bidder and target firm. This constitutes a significant gap in the literature.

In this paper, we examine how stock return volatility affects acquisition premiums through real options value of a firm. There are three rationales for investigating the effect of stock return volatility on M\&A premiums through real options value. Firstly, acquisition cases can be treated as real option opportunities. Grullon, Lyandres, and Zhdanov (2012) argue that positive relationship between stock return and stock return volatility is explained by the high real options of the firms. Real options as the growth options are impacted by R\&D intensity, stock return volatility, and financial and managerial flexibility according to real options theory (Smit \& Trigeorgis, 2012; Trigeorgis, 1996; Trigeorgis \& Lambertides, 2014). In M\&A situation, when a company acquires another firm, the high real options potential and high return volatility could lead to high premiums, because bidder firms may rationally pay high premiums in exchange for real option value and high return in the future. To be more specific, Laamanen (2007) reveals the positive relationship between R\&D intensity and takeover premiums. Furthermore, Chan et al. (2001) find that R\&D intensity and stock return volatility are positively related. Nevertheless, no previous paper investigates how the relationship between target's stock return volatility and M\&A premiums is explained by the growth option value of the firm. Thus, we examine and expect that significant M\&A premium is consistent with high stock return volatility and high real option value of target firm. 
Secondly, the return volatility is a component of product market uncertainty, and product market uncertainty has been found to have a positive effect on acquisition premiums. To be more specific, Lambrecht (2004) explains the reason for high takeover premiums by using real optionbased model. In his theoretical model, the higher M\&A premiums are associated with higher business risk of the target firms, larger size ratio between bidders and targets, and higher synergies. Sudarsanam and Sorwar (2010) apply the real option-based model to investigate the determinants of takeover premiums in the UK from 1990 to 2004. They reveal that business risk of targets and synergies in M\&A have a positive effect on takeover premiums. Business risk is estimated as the product of the target stock return volatility and the difference between one and the target leverage ratio (Sudarsanam \& Sorwar, 2010). Thus, stock return volatility of target firm might have a positive effect on M\&A premiums.

Thirdly, some researchers investigate the effect of idiosyncratic volatility and R\&D intensity on M\&A premium separately. For example, Chatterjee et al. (2012) and Zhu et al. (2014) use asymmetric information theory in the stock market to explain a positive relationship between idiosyncratic volatility and acquisition premiums. Additionally, R\&D intensity, which is a component of real option value of a firm, has been found to have a positive effect on M\&A premiums (Laamanen, 2007). No previous paper examines how stock return volatility and real option value affect acquisition premiums simultaneously. Hence, our research is focused on how stock return volatility affects acquisition premiums simultaneously.

For a sample of 2,559 M\&A deals in the U.S from 1986 to 2016, we find that when targets have more real options measured as high R\&D to market value, high sales growth rate, and low leverage ratio, the relationship between target return volatility and acquisition premiums is 
stronger. In other words, bidder firms tend to pay more premiums for the target firms that have more future real options value and higher risk. When the bidder volatility is higher than the target volatility, the bidder firms tend to pay fewer cash premiums when they have more risk. Our research contributes to a better understanding of the determinants of acquisition premiums. Notably, this thesis provides a preliminary test of the impact of the interaction between real option value and stock return volatility on M\&A premiums.

This article is structured as follows: Chapter 2 discusses some previous literature relating to our topic. Chapter 3 discusses the methodology and data collection procedure. Chapter 4 analyzes empirical results along with the results of our robustness tests. Chapter 5 discusses and explains essential results. Chapter 6 concludes the paper and propose recommendations. 


\section{CHAPTER 2}

\section{LITERATURE REVIEWS}

The purpose of this chapter is to review prior research and theories related to our research objectives. The literature review is structured as follows. Section 2.1 indicates the basic concept and definitions. Section 2.2 illustrates prior studies related to the research.

\subsection{Basic Concepts and Definitions}

\subsubsection{Mergers and Acquisitions Premium definition}

There are two methods to measure the acquisition premium. First, M\&A premium is calculated as the difference between the price offered by the bidder and the pre-announcement stock price of the target company, divided by pre-announcement stock price of the target company (Bange, 2004; Bris, 2001; Haunschild, 1994; Hayward \& Hambrick, 1997; Laamanen, 2007; Moeller, 2005; Zhu et al., 2014). The day in which the acquisition candidate receives its first official bid is the announcement date. The second way to estimate the acquisition premiums is by calculating the difference between the adjusted initial offer price and the stock price one month before announcement date (Slusky \& Caves, 1991; Sonenshine, 2010). The initial offer price for the acquisition is adjusted for the change in the S\&P 500 index during the one-month before the announcement.

The duration used to calculate the pre-announcement stock price is different among previous research papers. Most of the researchers use a one-month period as a pre-announcement period (Haunschild, 1994; Hayward \& Hambrick, 1997; Slusky \& Caves, 1991), while Bange (2004) calculates the average stock price from twenty trading days to one day before the announcement as the pre-offer stock price. However, Moeller (2005) uses the share price of target 
firms six days before the announcement day, and Robinson and Shane (1990) use 40 days before the announcement as the pre-announcement period.

\subsubsection{Stock return volatility}

There are two measurements of stock return volatility when investigating the relationship between M\&A premium and return volatility, which is total volatility and idiosyncratic volatility. Total volatility is the standard deviation of the stock return, while idiosyncratic volatility is estimated as the residual term form the Fama French three-factor model. Some research papers used the standard deviation of return as a measure of return volatility and risk when studying the impact of return volatility before and after acquisition announcement (Bhagat, Brickley, \& Loewenstein, 1987; Kumar, Dixit, \& Francis, 2015). Other researchers investigate the effect of idiosyncratic volatility on M\&A premium (Chatterjee et al., 2012; Zhu et al., 2014). Thus, understanding these two measurements is critical to investigate the determinants of the acquisition premiums.

\subsection{Prior Studies Related to the Research}

\subsubsection{Positive relationship between volatility and stock return is due to real option value}

Grullon et al. (2012) investigate the effect of stock return volatility and real option value on the return of a firm from 1963 to 200 . They reveal that the positive relationship between stock return volatility and stock return is stronger when the firms have higher real option value. In M\&A situation, the higher real option value and higher stock return volatility might have a positive effect on acquisition premiums. 


\subsubsection{The determinants of growth options}

Trigeorgis and Lambertides (2014) investigate the effect of growth option on the future stock return. They find that the growth option is negatively related to the future stock return. The reason for this is that the growth option is reflected in the current stock price. So, the future return is partially contained in the current stock price. According to real options theory, the growth options are impacted by R\&D intensity, stock return volatility, financial flexibility, organizational flexibility, and sales growth (Smit \& Trigeorgis, 2012; Trigeorgis, 1996; Trigeorgis \& Lambertides, 2014). Trigeorgis and Lambertides (2014) find that return volatility, R\&D intensity, and sales growth positively affect growth options of the firm. Financial flexibility is negatively related to the growth options. Furthermore, Trigeorgis and Lambertides (2014) also conclude that stock return volatility is more relevant than beta to value growth options.

Our research paper uses growth option theory to explain the effect of stock return volatility on M\&A premium. Paralleled with Trigeorgis and Lambertides (2014)'s conclusion, which is the growth options are reflected in the current stock prices, so in M\&A situation, when a company takeovers another firm, the growth option could lead to the high premiums. Thus, it is crucial to understanding the growth option components when investigating the determinants of $\mathrm{M} \& \mathrm{~A}$ premium.

\subsubsection{Determinants of M\&A premiums based on real option based theory}

Lambrecht (2004) explains the reason why takeover premium is high by using a real option-based model. In his theoretical model, the higher M\&A premium is associated with higher target's business risk, larger acquirer-to-target size ratio, and greater synergies. Lambrecht (2004) assumes that the purpose of acquiring another company is to maximize the stockholder value. This 
assumption can eliminate the agency problem, which has been found to affect M\&A premium (Shleifer \& Vishny, 1997). Also, Lambrecht (2004) make the second assumption for his real option-based model is that all bidders, targets, and investor have the same exposure to information. This assumption alleviates the CEO hubris, which Roll (1986) and Hayward and Hambrick (1997) finds contributes to the large takeover bid premiums.

Sudarsanam and Sorwar (2010) apply the real option-based theoretical model of Lambrecht (2004) to empirically investigate the determinants of takeover premiums during 1990 to 2004. They use 200 acquisition cases with cash payment in the UK. Instead of examining the total acquisition premium, they decompose the premium into the unobserved stock price and put option value. The real option-based model includes synergy effect, business risk, and relative size as the independent variables and M\&A premium as the dependent variable. Sudarsanam and Sorwar (2010) estimate the synergy effect as the relation between bidder and target firm industry. Business risk is estimated as the product of the target stock return volatility 250 trading days before M\&A announcement and the difference between 1 and the target leverage ratio (Sudarsanam \& Sorwar, 2010). Relative size is proxied as the ratio of bidder to target market value of the stock four weeks before acquisition announcement. In their results, they find that the business risk of acquired firms and synergies in M\&A have a positive effect on takeover premiums.

Lambrecht (2004) and Sudarsanam and Sorwar (2010) conclude that the business risk is positively correlated with acquisition premium. Furthermore, stock return volatility of the target firm is a component of business risk. Hence, there is a possibility that the return volatility of target firm and M\&A premium have a positive relationship. 


\subsubsection{Idiosyncratic volatility and $M \& A$ premium:}

Some previous research papers argue that bidder firms will pay high takeover premium if they have less exposure to target firm-specific information (Chatterjee et al., 2012; Zhu et al., 2014). Chatterjee et al. (2012) and Zhu et al. (2014) use idiosyncratic volatility as a measure of firm's stock price informativeness, and a reflection of the diversity of the investor opinion. Chatterjee et al. (2012) reveal the positive relationship between target firm's idiosyncratic volatility and acquisition premium in the US during the period of 1989 to 2004. Similarly, Zhu et al. (2014) investigate the relationship between idiosyncratic volatility and acquisition premium in 20 emerging countries from 1990 to 2007 and find that the idiosyncratic volatility of target firms is positively correlated with M\&A premium.

While Chatterjee et al. (2012) and Zhu et al. (2014) use asymmetric information theory to explain the effect of idiosyncratic volatility on takeover premium, our research paper uses real options theory to explain the relationship between M\&A premium and stock volatility. Furthermore, we use both total volatility and idiosyncratic volatility as the measures of return volatility.

\subsubsection{Research and Development (R\&D) Investment and M\&A premium:}

Laamanen (2007) investigates the effect of R\&D investment on acquisition premiums and acquisition returns of technology-intensive firms in the US from 1989 to 1999. This paper analyzed 458 observations, collected from the SDC Mergers and Acquisitions database combined with CRSP, COMPUSTAT, and the US Patent Office databases. The results reveal that the four-year average $R \& D$ investment and four-year average $R \& D$ investment growth rate of target firms each 
have a significantly positive effect on M\&A premiums. However, acquisition premiums do not contribute to the observed negative abnormal returns.

The results of the positive relationship between $R \& D$ investment and takeover premium from Laamanen (2007)'s paper are based on 458 observations. We will extend the significance of the results by examining 2,559 acquisition deals in the U.S. Also, while Laamanen (2007) focus on only technology firms, we will broaden the study to all industries.

\subsubsection{Other factors affecting mergers and acquisitions premium}

In this section, we review some previous research related to the determinant of M\&A premium. We use some variable as the control variables, and some will not be used as the control variables. The variables that we use as the control variables are divided into four main groups, including synergy effects, deal characteristics, target firm characteristics, and bidder firm characteristics.

\section{- Synergy effects}

\section{○ Industry relatedness}

Synergy effect is estimated as the relation between acquirer and target firms. To be more specific, if the bidder firm acquires other company in the same industry, the synergy effect would be higher. Various previous researchers investigate the effect of industry relatedness on acquisition premium, yet the results are inconsistent (Haunschild, 1994; Hayward \& Hambrick, 1997; Jindra \& Moeller, 2015; Laamanen, 2007; Moeller, 2005; Zhu et al., 2014). Haunschild (1994) and Hayward and Hambrick (1997) find that there is no relationship between industry relatedness and M\&A premiums. However, some research papers reveal that industry relatedness is significantly negatively related to takeover premium (Laamanen, 2007; Moeller, 2005). In contrast, Sudarsanam 
and Sorwar (2010) and Zhu et al. (2014) find that high acquisition premium is associated with high industry relatedness.

\section{○ Financial synergy}

Hayward and Hambrick (1997) include financial synergy as the control variable when investigating the determinants of acquisition premiums. Financial synergy is estimated as the difference between debt to equity ratio of target and bidder firm in one year before M\&A. They find that financial synergy and acquisition premiums are unrelated.

\section{$\circ$ Relative size of bidder and target}

Relative size of the acquired firm and acquirer firm has been found to have a negative effect on M\&A premiums by various researchers (Chatterjee et al., 2012; Jindra \& Moeller, 2015; Moeller, 2005). However, Hayward and Hambrick (1997), Slusky and Caves (1991), and Sudarsanam and Sorwar (2010) find that there is no relationship between relative size and acquisition premium. Hayward and Hambrick (1997) and Slusky and Caves (1991) use sales of the target to sales of the acquirer ratio as the relative size. Besides that, other researchers indicate the ratio of target to bidder market value of equity as the relative size (Chatterjee et al., 2012; Jindra \& Moeller, 2015; Moeller, 2005; Sudarsanam \& Sorwar, 2010).

\section{- Deal characteristics}

\section{○ Number of competing bids}

There are various previous studies that find that more competing bids are associated with higher M\&A premiums (Giliberto \& Varaiya, 1989; Haunschild, 1994; Hayward \& Hambrick, 1997; Jahera, Hand, \& Lloyd, 1985; Shelton, 2000; Slusky \& Caves, 1991; Varaiya, 1988; Varaiya 
\& Ferris, 1987; Walkling \& Edmister, 1985; Zhu et al., 2014). Furthermore, Haunschild (1994) indicates that the number of competing bids is the most influential predictor of high takeover bid premiums. However, Laamanen (2007) investigates mergers in technology-based firms and concludes that the number of competing bids is not a factor contributing to high M\&A premiums. Various previous research papers mention the number of competing bids as a control variable and find that it has no significant effect on acquisition premium (Chan et al., 2001; Chatterjee et al., 2012; Moeller, 2005; Sonenshine, 2010).

\section{○ Method of payment}

M\&A premium is higher with cash deals than stock deals (Chan et al., 2001; Franks \& Harris, 1989; Moeller, 2005; Niden, 1988; Robinson \& Shane, 1990; Slusky \& Caves, 1991; Travlos, 1987). Several researchers include methods of payment as a control variable when investigating the determinants of M\&A premiums, yet the results are insignificant (Chatterjee et al., 2012; Hayward \& Hambrick, 1997; Laamanen, 2007; Zhu et al., 2014).

\section{○ Tender offers}

Some research papers reveal that deals are described as the tender offer have high acquisition premium than other deals (Chatterjee et al., 2012; Jindra \& Moeller, 2015; Zhu et al., 2014). In contrast, Moeller (2005) find a significant negative relationship between acquisition premium and tender offer. 


\section{○ Mergers of equals}

When investigating the relationship between M\&A premium and $R \& D$ intensity, Laamanen (2007) include mergers of equals as a control variable to the model and find that the larger mergers of equals are significantly associated with lower takeover premiums.

\section{○ Deal size}

Deal size has been used as a control variable when investigating the determinants of M\&A premium (Chan et al., 2001; Haunschild, 1994; Hayward \& Hambrick, 1997; Sonenshine, 2010). Chan et al. (2001) and Sonenshine (2010) find that transaction size and acquisition premium are negatively correlated. However, Zhu et al. (2014) reveal that acquisition premium is significantly high in an acquisition deal with tremendous value in twenty emerging countries.

\section{○ Hostile acquisition}

Deal attitude has been included as a control variable when investigating the determinants of M\&A premium. To be more specific, several research papers find that hostile takeover has a positive effect on acquisition premium (Chatterjee et al., 2012; Jindra \& Moeller, 2015; Servaes, 1991; Sudarsanam \& Sorwar, 2010).

\section{○ Number of days to effective}

Moeller (2005) controls for the number of days to effective when examining the factors affect acquisition premium. He finds a negative relationship between the number of days to effective variable and M\&A premium, yet the results are insignificant. 
- Target firm characteristics

- Target resistance to takeover

Poison pills of acquired firm is an indicator of target resistance to takeover, which affects the M\&A premium (Chan et al., 2001; Hayward \& Hambrick, 1997; Malatesta \& Walkling, 1988; Sinha, 1992). Moreover, resistance to takeover by the target firm has been found to be positively correlated with M\&A premiums (Baron, 1983; Laamanen, 2007; Sinha, 1992).

\section{○ Target firm size}

Target firm size has been found to have a negative effect on M\&A premium, which means the higher target firm size, the lower acquisition premium (Bange, 2004; Chan et al., 2001; Chatterjee et al., 2012; Schwert, 2000; Zhu et al., 2014). Target firm size is identified as the total assets of acquired firms one year prior to acquisition announcement (Bange, 2004; Chan et al., 2001; Moeller, 2005; Schwert, 2000). Chatterjee et al. (2012) measure the target market value as the size of the acquired firm and find the negative relationship between target firm size and acquisition premium. Laamanen (2007) use target firm sales as the control variable, yet no significant results have been found.

\section{○ Market to book of target}

Some research papers include market to book of acquired firm as a control variable when investigating the determinants of M\&A premiums and find that bidder firm tend to pay high premium for the target with low market to book ratio (Chatterjee et al., 2012; Jindra \& Moeller, 2015; Laamanen, 2007; Zhu et al., 2014). They use the market to book ratio of target to control for the level of stock misevaluation of acquired company before acquisition announcement. 


\section{○ Return on asset of target}

Return on asset of the acquired firm has been found to have a positive effect on takeover premium (Bauguess, Moeller, Schlingemann, \& Zutter, 2009; Jindra \& Moeller, 2015), albeit the results are insignificant.

\section{○ Return on equity of target}

Return on equity of target company has been mentioned as a control variable for the study of what factors affect M\&A premium by some researchers (Laamanen, 2007; Slusky \& Caves, 1991). However, there is no significant relationship has been found.

\section{○ Operating cash flow of target}

Several research papers mention target's operating cash flows as a control variable when examining the determinants of M\&A premium (Bauguess et al., 2009; Jindra \& Moeller, 2015). In that, Bauguess et al. (2009) find that high acquisition premiums are associated with high operating cash flows of the target firm. However, the result is insignificant.

\section{- Target financial independence}

Jindra and Moeller (2015) apply the bargaining power hypothesis to investigate the determinants of M\&A premium. In this hypothesis, target firm with high financial independence will have higher barging power. So, the target will get higher premiums paid by the bidder. They reveal a significant positive relationship between financial independence of target firm and takeover premium. 


\section{○ Target debt-to-equity}

Walkling and Edmister (1985) mention debt to equity ratio of the targets as a control variable when investigating factors affect acquisition premium and find that high M\&A premiums are associated with the low debt-to-equity ratio of the target firms.

\section{- Bidder firm characteristics}

○ Public bidder

Bidder firm is publicly listed or privately listed could affect acquisition premium. To be more specific, mention public acquirer as a control variable when examining the effect of idiosyncratic volatility and takeover premium in the UK from 1990 to 2007. They find that public bidder firms tend to pay higher acquisition premium than private bidder firms.

\section{- Percentage of target's share owned by bidder before and after $M \& A$}

The percentage of target's shares owned by bidder prior to acquisition announcement, bidder toehold, has been considered as a factor affect M\&A premium in various previous research papers (Betton \& Eckbo, 2000; Bulow, Huang, \& Klemperer, 1999; Burkart, 1995; Chan et al., 2001; Chatterjee et al., 2012; Franks \& Harris, 1989; Lambrecht, 2004; Singh, 1998). Some researchers find a negative relationship between bidder toehold and M\&A premium (Betton \& Eckbo, 2000; Chatterjee et al., 2012). In contrast, Franks and Harris (1989) reveal that higher acquirer toehold is associated with larger acquisition premium. 


\section{- Non-control variables:}

○ Interlock partners

Haunschild (1994) finds that acquisition premium paid by interlock partners have a positive effect on M\&A premiums. Bidder companies, which are defined as the interlock partners, are the firms who shared the outside directors with the target firms.

\section{○ Investment advisor of bidder}

Haunschild (1994) indicates that M\&A premiums paid by acquirers are highly correlated with premiums paid by other companies who use the same investment bank. However, Laamanen (2007) finds that there is no evidence of systematic differences among investment advisors.

\section{○ CEO hubris}

Hayward and Hambrick (1997) reveal that CEO hubris and acquisition premium are positively correlated. They introduce three indicators of CEO hubris: the recent performance of bidder company, the recent media praise for CEO, and a measure of CEO's self-importance. They measure recent bidder performance as stockholder returns for one year before the acquisition. CEO self-importance is measured by CEO relative compensation. Media praise for CEOs is determined through content analysis of major newspaper and magazines.

\section{- Shareholder Ownership Structure}

Bange (2004) finds that before 1991 the initial takeover price is lower if outside directors represent a majority of the board. In contrast, Moeller (2005) uses the M\&A data from 1990 to 1999 to investigate the effect of shareholder ownership structure on takeover premium and reveal that the larger the number of outside block-holders, the higher the takeover premium. 


\subsection{Limitations}

According to previous research papers, interlock partner, CEO hubris and shareholder ownership structure variables are also the factors affect acquisition premiums. However, the data for those variables are not available. Thus, we exclude them from the control variables. 


\section{CHAPTER 3}

\section{METHODOLOGY}

In this chapter, we begin by explaining the research method used in this study. An explanation of the strategy and how we collected our data as well as sample selection will also be explained. Our research objective is to investigate the relationship between the stock return volatility of target companies and M\&A premiums. The research methods that will be adopted in this paper is a deductive method with an empirical analysis. The first thing to do is to identify the problems surrounding the factors affecting the M\&A premium. Then, we collect data and formulate a hypothesis. Finally, we use statistical tools and techniques to analyze our data to test whether our hypothesis was correct.

\subsection{Sampling, data collecting procedure}

We collect data from the Securities Data Corporation (SDC) Mergers and Acquisitions database. Then, the SDC data are complemented with data from Center for Research in Securities Prices (CRSP) and Compustat databases. In CRSP database, we collect stock price and Standard and Poor's (S\&P) data. The information form balance sheets, income statements, and cash flow statements are obtained from Compustat database. The initial sample includes 37,031 observations, which consists of all U.S mergers and acquisitions from 1986 to 2016 with over $\$ 100$ million deal value. Then, we keep 10,222 observations with available acquisition premiums from SDC Mergers and Acquisition database. After that, we filter out only transactions with the completed deals. This requirement leaves 6651 transactions. After that, we only keep the deals with public target firms, in which the data of the targets must be available from Compustat and CRSP database. The remaining sample is 4183 deals. Then, we check if the data items for bidder 
firms are available on CRSP and Compustat database. The final full sample with available both bidder and target data consists of 2,559 observations. Our sample is comparable to the latest paper about M\&A premiums and idiosyncratic volatility in U.S. Their data contains 2,069 deals with available target information (Chatterjee et al., 2012).

\subsection{Variable Constructions}

\subsubsection{Independent variable: Mergers and acquisitions premium}

There are two ways to measure M\&A premium. The first method is that M\&A premium is calculated as the difference between the price offered by the bidder and the pre-announcement stock price of the target company, divided by the pre-announcement stock price of the target company (Bange, 2004; Bris, 2001; Haunschild, 1994; Hayward \& Hambrick, 1997; Laamanen, 2007; Moeller, 2005; Zhu et al., 2014) . The day in which the acquisition candidate received its first official bid is the announcement date. In this paper, we use the stock price one month before acquisition announcement as the pre-announcement stock price. The formula is constructed as follows:

$$
M \& A \text { premium }=\frac{P_{M \& A}-S_{i}}{S_{i}}
$$

- PM\&A: Initial offer price for the acquisition

- $\mathrm{S}_{\mathrm{i}}$ : Stock price of target firm i one-month before announcement

The second way to estimate the acquisition premium is to calculate the difference between the adjusted initial offer price and the market price one month before announcement date (Slusky \& Caves, 1991; Sonenshine, 2010). The initial offer price for the acquisition is adjusted for the 
change in the S\&P 500 index during one month before announcement. The formula is constructed as follows:

$M \& A$ premium $(S \& P 500$ adjusted $)=\frac{P_{M \& A} *(1-\% \Delta S \& P)-S_{i}}{S_{i}}$

- $\mathrm{P}_{\mathrm{M} \& \mathrm{~A}}$ : Initial offer price for the acquisition

- S\&P: S\&P 500 stock market index

- $\mathrm{S}_{\mathrm{i}}$ : Stock price of target firm i one-month before announcement

The data is taken from SDC Mergers and Acquisition database.

\subsubsection{Dependent variables: Growth options variables}

The primary dependent variables are growth options variables, including stock return volatility, R\&D intensity, organizational flexibility, financial flexibility, and target sales growth.

\section{- Stock Return Volatility}

There are two measurements of stock return volatility, including total volatility and idiosyncratic volatility. The first one is the total volatility, which is estimated as the standard deviation of the stock return for each firm during 252 trading days prior to the acquisition announcement.

The equation to estimate stock return:

$$
R_{t}=\ln \left(\frac{P_{t}}{P_{t-1}}\right)
$$

$R_{t}$ is stock return from date $\mathrm{t}-1$ to date $\mathrm{t}$

$P_{t}$ is closing price of stock at time $\mathrm{t}$ 
$P_{t-1}$ is closing price of stock at time t-1

The equation to estimate standard deviation:

$$
\mathrm{S}_{\mathrm{i}}=\sqrt{\frac{\sum\left(R_{i}-\overline{R_{l}}\right)^{2}}{252-1}}
$$

$S_{i}$ is the standard deviation of company i during 252 days before M\&A announcement

$R_{i}$ is daily stock return of company i during 252 days before M\&A announcement

The second measurement is the idiosyncratic volatility. We use Fama-French three-factor model to estimate the idiosyncratic volatility. We run regressions of Fama-French three factors model for each company during 252 trading days before acquisition announcement to get the residuals of the model. The square roots of the residuals form the Fama-French three-factor model divided by 251 are the idiosyncratic risk of the company. The Fama-French three-factor model is as followed:

$$
R_{i, t}-R_{f, t}=\alpha_{i}+\beta_{i} R_{m, t}+\gamma R_{s m b, t}+\delta_{i} R_{h m l, t}+\varepsilon_{i}
$$

$R_{i, t}$ is the return of company $\mathrm{i}$ in time $\mathrm{t}$

$R_{f, t}$ is the risk-free return rate (one month treasury bill rate) in time $\mathrm{t}$

$R_{m, t}$ is the excess market return over thee risk-free return rate where the market return is the value weighted return on all stocks in time $\mathrm{t}$

$R_{S m b, t}$ is the difference between small firms return and big firms return in time $\mathrm{t}$

$R_{h m l, t}$ is the difference between high book to market equity return and low book to market equity return in time $\mathrm{t}$ 
$\varepsilon_{i}$ is the residual sum of squares of the model of company $i$

$$
I_{i}=\sqrt{\frac{\varepsilon_{i}}{252-1}}
$$

$I_{i}$ is the idiosyncratic volatility of firm $\mathrm{i}$

$\varepsilon_{i}$ is the residual sum of squares of the model of company $i$

\section{- $\quad R \& D$ Intensity}

$\mathrm{R} \& \mathrm{D}$ investment is a standard accounting item, which is explicitly available in financial statements. There are four measurements of $R \& D$ intensity. Firstly, $R \& D$ intensity is measured as the recent 3-years period R\&D investment to sales (Trigeorgis \& Lambertides, 2014). The second measurement of $R \& D$ intensity is the ratio of $R \& D$ expense to the market value of equity (Chan et al., 2001; Laamanen, 2007). Thirdly, R\&D growth rate is measured as the average R\&D investment growth rate of the target firms during the three years before the acquisition announcement (Laamanen, 2007). R\&D expenses, sales, and market value of target firm are obtained from Compustat database. The missing $R \& D$ values are set to 0 (Trigeorgis \& Lambertides, 2014).

$$
R \& D \text { to sales }=\left(\frac{R \& D_{t-3}}{\text { Sales }_{t-3}}+\frac{R \& D_{t-2}}{\text { Sale }_{t-2}}+\frac{R \& D_{t-1}}{\text { Sale }_{t-1}}\right) / 3
$$

$$
R \& D \text { to market value }=\frac{\text { Target }^{\prime} s R D \text { investment } 1 \text { year pre announement }}{\text { Target's market value } 4 \text { weeks pre announcement }}
$$




\section{$R \& D$ growth rate}

$=$ average $R \& D$ expenses growth rates during 3 years pre announcement

\section{- Organizational flexibility}

The organizational flexibility of the firm is estimated as the ratio of selling, general, and administrative (SGA) expenses to sales of the target firms. The data is collected from Compustat database.

\section{- Financial flexibility}

According to Trigeorgis and Lambertides (2014), there are two measurements of financial flexibility. The first one is the leverage of firm, which is proxied as the ratio of total debt and total assets one year before M\&A announcement. Also, financial flexibility is estimated as the cash flow coverage of the firm, which is calculated as the ratio of operating cash flows and total debt of the firm in a fiscal year before acquisition announcement. The data is obtained from Compustat database.

\section{- Sales growth}

Sales growth is estimated as the average growth rate of the firm sales during 3 years before acquisition announcement. The data is obtained from Compustat database.

\subsubsection{Control Variables}

Base on the literature review, we control for other variables that affect or have been proposed to affect the M\&A premium. We categorize 23 control variables into four groups, including synergy effect, deal characteristics, target firm characteristics, and bidder firm characteristics. 
- Synergy effect

○ Industry relatedness

Two companies are identified as related when they share the same Standard Industry Classification (SIC) code (Haunschild, 1994; Hayward \& Hambrick, 1997; Laamanen, 2007; Moeller, 2005; Sudarsanam \& Sorwar, 2010; Zhu et al., 2014). Target and bidder firm have industry relatedness when they share two first digits SIC codes. We then create a dummy variable which equals 1 when bidder and target share two first digits SIC codes, otherwise 0. SIC codes are obtained in SDC Mergers and Acquisition database.

\section{○ Financial synergy}

Financial synergy is estimated as the difference between debt to equity ratio of target and bidder firm in one year before M\&A announcement (Hayward \& Hambrick, 1997). We collect financial synergy data in Compustat database.

\section{$\circ$ Relative size of bidder and target}

There are two measurements of relative size. According to Hayward and Hambrick (1997), relative size is estimated as the total sales of the target to total sales of the bidder at the last fiscalyear end before acquisition announcement. The second measurement is that relative size variable is proxied as the ratio of target to bidder market value of stock in 4 weeks prior to M\&A announcement (Chatterjee et al., 2012; Jindra \& Moeller, 2015; Moeller, 2005; Sudarsanam \& Sorwar, 2010). In this paper, we consider both sales and market value as the size measurement. The data for assets and sales taken from Compustat database. The market value data is collected from WRDS database. 
- Deal characteristic

○ The number of competing bids

The number of competing bids data is taken from the SDC Mergers and Acquisition database. We then create a dummy variable categorized as 1 if M\&A deal has one or more than one competing bidders, and 0 if the deal has no competing bidder.

\section{○ The method of payment}

To control for payment method, we create three dummy variables. The first dummy variable which equals 1 if the acquisition paid in pure cash, otherwise 0 . The second dummy variable which equals 1 if the acquisition paid in pure stock, otherwise 0 . The third dummy variable which equals 1 if the acquisition paid in mix of stock and cash, otherwise 0 . Data for the method of payment variable is collected form SDC Mergers and Acquisition database.

○ Tender offer

To control for the tender offer, we collect the tender offer information from Mergers and Acquisition database. We then create a dummy variable, which equals 1 for deals with the tender offer, and 0 for otherwise.

\section{$\bigcirc \quad$ Mergers of equals}

Mergers of equals variable is obtained in SDC Mergers and Acquisition database. We code 1 for deals with mergers of equals, and 0 for deals without mergers of equals. 


\section{○ Deal size}

We measure the deal size as the log of acquisition transaction deal value, which is obtained from SDC Mergers and Acquisition database.

\section{○ Hostile acquisition}

To control for hostile acquisition, we collect deal attitude variable from SDC Mergers and Acquisition database. We then code 1 for hostile deals and 0 for friendly deals.

\section{○ Number of days to effective}

The number of days to effective variable is proxied as the difference between the effective date and the announcement date of M\&A deal. Data is collected from SDC Mergers and Acquisition database.

- $\quad$ Target firm characteristics

○ Target business risk

Target business risk variable is estimated as the product of return volatility of target firm 252 days before the announcement and the difference between 1 and target leverage ratio in one year before the M\&A announcement. Data is obtained from CRSP and SDC Mergers and Acquisition database.

\section{- Target resistance to takeover}

We create a dummy variable for the existence of a poison pill, as poison pills are the indication of target resistance to takeover (Chan et al., 2001; Hayward \& Hambrick, 1997; Malatesta \& Walkling, 1988; Sinha, 1992). The dummy variable takes a value of 1 for firms with 
a poison pill and 0 for firms without a poison pill. The poison pill information is available in SDC Mergers and Acquisition database.

\section{○ Target firm size}

According to previous literature, there are two measures of target firm size. Firstly, Chatterjee et al. (2012) measure the target market value as the size of the acquired firm. The second measure of target firm size is the sales of target firm (Laamanen, 2007). Thus, we consider both target market value four weeks before the announcement, and sales of the target in one fiscal year before the announcement as the indications of target firm size. Data is collected in Compustat database. Then we calculate the logarithm of sales, assets, and market value.

\section{○ Market to book of target}

Target's market to book variable is measured as the ratio of market value of the acquired firm four weeks before M\&A announcement and book value of target firm in the last fiscal year before M\&A announcement. The data is obtained from Compustat database.

\section{○ Return on asset of target}

Return on asset is estimated as the ratio of net income and total asset of target firm in the last fiscal year before the acquisition announcement. Data for net income and asset are collected from Compustat database.

\section{○ Return on equity of target}

To control for return on equity of target firm, we collect the net income and shareholder's equity of the targets in one year before the announcement. Then we calculate the ratio of net income and equity. Data are obtained from Compustat database. 


\section{○ Operating cash flows of target}

We measure the target's operating cash flows as the ratio of operating cash flows and sales of target firm in one fiscal year prior to the acquisition announcement. The data are collected from Compustat database.

\section{- Target financial independence}

Target financial independence is estimated as the difference between cash in two years before the announcement and operating cash flows in one year before acquisition announcement divided by target total assets in one year before the announcement. Data are taken from Compustat database.

\section{○ Target debt to equity}

Debt to equity ratio of the target is proxied as the total debt is divided by total equity of target firm one year prior to M\&A announcement. Debt and stockholder's equity of target firms are collected from Compustat database.

\section{- Bidder firm characteristics}

\section{○ Public bidder}

Public acquirer data are collected from SDC Mergers and Acquisition database. To control for the public acquirer, we create a dummy variable categorized as 1 if the bidder firms are listed publicly, and 0 if otherwise. 


\section{- Percentage of target's share owned by bidder before and after M\&A}

To control for the percentage of target's share owned by bidder before and after M\&A, we collect the data for the percentage of target's share held by bidders before and after the announcement from SDC Mergers and Acquisition database.

\subsection{Hypothesis statement}

This study aims to studies the how stock return volatility affects acquisition premiums through real option values contained in the bidders and targets. Grullon et al. (2012) find that positive relationship between stock return and stock return volatility is explained by the high real options of the firms. In M\&A situation, when a company acquires another firm, the high real options potential and high return volatility could lead to high premiums, because bidder firms may rationally pay high premiums in exchange for real option value and high return in the future. We construct our hypothesis as follows:

H1: The higher stock return volatility of target firms before M\&A announcement, the higher the M\&A premium.

$\mathrm{H} 2$ : The positive relationship between target stock return volatility and M\&A premiums is stronger when target firms have high future growth options.

\subsection{Data Analysis Methodology}

Concerning the data analysis methodology, ordinary least squares (OLS) regressions are used to identify the effect of stock return volatility on M\&A premium through real option value the firm. According to the hypothesis proposed, the models are constructed as follow: 
- $\mathrm{M} \& \mathrm{~A}$ Premiums $=\alpha+\beta_{1}$ target volatility $+\beta_{2}$ bidder volatility $+\beta_{3}$ real option variables of targets $+\beta_{4}$ real option variables of bidders $+\beta_{5}$ Control variables

- M\&A Premiums $=\alpha+\beta_{1}$ target volatility $+\beta_{2}$ bidder volatility $+\beta_{3}$ real option variables of targets $+\beta_{4}$ real option variables of bidders $+\beta_{5}$ Control variables $+\beta_{6}$ Interaction terms between targets return volatility and real option variable of targets + $\beta_{7}$ Interaction terms between bidders return volatility and real option variable of bidders

The first model is constructed to answer the hypothesis 1 , which is the higher stock return volatility of the target firm, the higher acquisition premium. In order to answer the hypothesis 2 , we add the interaction terms between return volatility and real option variables of bidders and targets to the first model. In these two models, M\&A Premium is the dependent variable. Target volatility, bidder volatility, and real option variables are main independent variables, which answer our research objectives. Real option value variables for the targets include target R\&D to market value, target $R \& D$ to sales, target $R \& D$ growth rate, organizational flexibility of target, financial flexibility of target (leverage), financial flexibility of target (cashflow coverage), and sales growth of target. Real option value variables for the bidders contain bidder R\&D to market value, bidder R\&D to sales, bidder R\&D growth rate. Control variables comprise of industry relatedness, financial synergy, relative size, number of competing bids, method of payment, tender offers, mergers of equals, deal size, hostile acquisition, number of day to effective, target resistance to takeover, target business risk, target firm size, target market to book ratio, target ROA, target ROE, target operating cash flow, target financial independence, target debt to equity, public bidder, and percentage of targets' share owned by bidders before and after announcement. STATA software is used to run the regressions. 


\subsection{Limitation and Potential problems}

CUSIP (Committee on Uniform Security Identification Procedures) numbers are used differently in three databases, which are SDC Mergers and Acquisition database, Compustat database, and CRSP database. CUSIP 6 digits are used in SDC Mergers and Acquisition database. However, Compustat database and CRSP database use 9 digits CUSIP and 8 digits CUSIP respectively. Due to the difficulty in matching the CUSIP 6 digits, CUSIP 8 digits, and CUSIP 9 digits, and the time constraints, some observations, approximately $10 \%$ of the total observations, are dropped in our sample. 


\section{CHAPTER 4}

\section{EMPIRICAL RESEARCH FINDING}

This chapter presents the description of the data collected and an analysis of the research results. Firstly, the brief descriptive statistics are provided. Then, regression analysis for M\&A premiums, stock return volatility, real option variables, and control variables are discussed.

\subsection{Descriptive Statistics}

\subsubsection{Describe $M \& A$ statistics by years}

Table 1 illustrates the statistics of acquisitions deal by years. The U.S experienced a significant increase in M\&A deals from 1986 to 1999, which soared from 47 deals to 202 deals. After reaching the highest level at 202 deals, the number of acquisition deals plummeted to 51 deals in 2002 , followed by a graduate increase to 111 transactions in 2007 . After that, the number of M\&A deals fluctuate around 53 transactions from 2008 to 2016.To sum up, the deal number initially achieved the highest level in 1999, are then set to drop steadily throughout the next three years, before remaining constant until 2016.

As regards the average deal value, from 1986 to 1997, the average deal transaction value remained constant at approximately 900 million dollars. After that, it increased considerably to $5,074.59$ million dollars in 2009 , followed by a significant decrease to $1,454.34$ million dollars in 2012. The average deal value reached a peak of 5,764.37 million dollars in 2015, before declining to 3,712.98 million dollars in 2016. The average transaction value escalated gradually from 1986 to 2015 , then dropped steadily in 2016. 
Table 1: M\&A statistics by years

\begin{tabular}{|c|c|c|c|c|}
\hline Year & $\begin{array}{c}\text { Number of } \\
\text { M\&A }\end{array}$ & $\begin{array}{c}\text { Average } \\
\text { transaction value } \\
\text { (million \$) }\end{array}$ & $\begin{array}{c}\text { Total transaction } \\
\text { value (million \$) }\end{array}$ & $\begin{array}{c}\text { Percentage of } \\
\text { transaction value } \\
\text { (\%) }\end{array}$ \\
\hline $\mathbf{1 9 8 6}$ & 47 & 697.02 & $32,760.16$ & $0.59 \%$ \\
\hline $\mathbf{1 9 8 7}$ & 50 & 796.57 & $39,828.37$ & $0.72 \%$ \\
\hline $\mathbf{1 9 8 8}$ & 41 & 672.61 & $27,576.88$ & $0.50 \%$ \\
\hline $\mathbf{1 9 8 9}$ & 53 & 628.54 & $33,312.46$ & $0.60 \%$ \\
\hline $\mathbf{1 9 9 0}$ & 25 & 378.06 & $9,451.42$ & $0.17 \%$ \\
\hline $\mathbf{1 9 9 1}$ & 21 & 620.47 & $13,029.81$ & $0.23 \%$ \\
\hline $\mathbf{1 9 9 2}$ & 39 & 819.23 & $31,950.13$ & $0.58 \%$ \\
\hline $\mathbf{1 9 9 3}$ & 44 & 979.83 & $43,112.57$ & $0.78 \%$ \\
\hline $\mathbf{1 9 9 4}$ & 55 & 831.21 & $45,716.48$ & $0.82 \%$ \\
\hline $\mathbf{1 9 9 5}$ & 102 & $1,103.24$ & $112,530.21$ & $2.03 \%$ \\
\hline $\mathbf{1 9 9 6}$ & 111 & $1,052.83$ & $116,864.09$ & $2.10 \%$ \\
\hline $\mathbf{1 9 9 7}$ & 182 & 951.48 & $173,168.69$ & $3.12 \%$ \\
\hline $\mathbf{1 9 9 8}$ & 192 & $2,942.05$ & $564,873.96$ & $10.17 \%$ \\
\hline $\mathbf{1 9 9 9}$ & 202 & $2,535.48$ & $512,166.56$ & $9.22 \%$ \\
\hline $\mathbf{2 0 0 0}$ & 174 & $3,689.47$ & $641,967.53$ & $11.56 \%$ \\
\hline $\mathbf{2 0 0 1}$ & 114 & $1,745.04$ & $198,934.66$ & $3.58 \%$ \\
\hline $\mathbf{2 0 0 2}$ & 51 & $1,929.90$ & $98,425.07$ & $1.77 \%$ \\
\hline $\mathbf{2 0 0 3}$ & 87 & $1,393.36$ & $121,221.96$ & $2.18 \%$ \\
\hline $\mathbf{2 0 0 4}$ & 99 & $2,245.88$ & $222,342.28$ & $4.00 \%$ \\
\hline $\mathbf{2 0 0 5}$ & 97 & $3,468.85$ & $336,478.37$ & $6.06 \%$ \\
\hline $\mathbf{2 0 0 6}$ & 106 & $1,739.42$ & $184,378.69$ & $3.32 \%$ \\
\hline $\mathbf{2 0 0 7}$ & 111 & $1,824.33$ & $202,500.89$ & $3.64 \%$ \\
\hline $\mathbf{2 0 0 8}$ & 52 & $1,891.05$ & $98,334.49$ & $1.77 \%$ \\
\hline $\mathbf{2 0 0 9}$ & 44 & $5,074.59$ & $223,282.17$ & $4.02 \%$ \\
\hline $\mathbf{2 0 1 0}$ & 71 & $1,525.55$ & $108,314.23$ & $1.95 \%$ \\
\hline $\mathbf{2 0 1 1}$ & 49 & $2,550.11$ & $124,955.44$ & $2.25 \%$ \\
\hline $\mathbf{2 0 1 2}$ & 53 & $1,454.34$ & $77,080.18$ & $1.39 \%$ \\
\hline $\mathbf{2 0 1 3}$ & 59 & $2,050.29$ & $120,967.12$ & $2.18 \%$ \\
\hline $\mathbf{2 0 1 4}$ & 69 & $3,991.85$ & $275,437.50$ & $4.96 \%$ \\
\hline $\mathbf{2 0 1 5}$ & 85 & $5,764.37$ & $489,971.17$ & $8.82 \%$ \\
\hline $\mathbf{2 0 1 6}$ & 74 & $3,712.98$ & $274,760.68$ & $4.95 \%$ \\
\hline $\mathbf{T o t a l}$ & 2559 & $61,060.00$ & $5,555,694.18$ & $100.00 \%$ \\
\hline & & & & \\
\hline
\end{tabular}




\subsubsection{Summary statistics of acquisition premium and growth option variables}

We present descriptive statistics for M\&A premiums and return volatility variable of targets and bidders in table 2. With 2559 observations, the takeover premium which is adjusted with S\&P 500 index ranges from -1.1783 to 4.5933 with an average of 0.3394 and standard deviation of 0.3944 . Similarly, the original measurement of M\&A premiums has approximately the same descriptive statistics as the $\mathrm{S} \& \mathrm{P}$ adjusted M\&A premiums, which ranges from -0.8889 to 4.8036 . The mean and standard deviation for the acquisition premiums variable are 0.3550 and 0.3973. As regards the volatility, the mean of target and bidder total return volatility are 0.0301 and 0.0297 respectively. However, the idiosyncratic volatility of target and bidder are slightly lower than the total volatility. The mean of target idiosyncratic volatility is 0.0290 and bidder idiosyncratic volatility is 0.0274 .

Real option variables for acquired firms contain target $R \& D$ to market value, target $R \& D$ to sales, target R\&D growth, target organizational flexibility, target financial flexibility (leverage), and target financial flexibility (cashflow coverage). The mean of target R\&D to market value, target $R \& D$ to sale, and target $R \& D$ growth rate are $0.0256,0.3285$, and 0.1280 respectively. Also, target organizational flexibility variable has 2559 observations with the mean of 0.2587 and standard deviation of 0.9092 . The mean for financial flexibility with leverage measure, and cash flow coverage measure are 0.5826 and 0.1091 respectively. Target sales growth ranges from 0.7758 to $2,680.68$ with the average of 1.9053 and the standard deviation of 56.6573 .

Real option variables for bidder firms include bidder R\&D to market value, bidder R\&D to sales, and bidder R\&D growth. With 2559 observations, the bidder R\&D to market value 
variable ranges from 0 to 19.92 with an average of 0.1368 . The means of bidder R\&D to sales and R\&D growth variables are 0.0379 and 0.1023 respectively.

Table 2: Summary statistics of acquisition premium and growth option variables

\begin{tabular}{|l|c|c|c|c|c|}
\hline Variable & Observations & Mean & Std. Dev. & Min & Max \\
\hline M\&A premiums with S\&P adjustment & 2559 & 0.3394 & 0.3944 & -1.1783 & 4.5933 \\
\hline M\&A Premium & 2559 & 0.3550 & 0.3973 & -0.8889 & 4.8036 \\
\hline Target idiosyncratic volatility & 2559 & 0.0276 & 0.0154 & 0.0058 & 0.1458 \\
\hline Target volatility & 2559 & 0.0301 & 0.0161 & 0.0059 & 0.1471 \\
\hline Bidder idiosyncratic volatility & 2559 & 0.0255 & 0.0196 & 0.0024 & 0.2917 \\
\hline Bidder volatility & 2559 & 0.0297 & 0.0216 & 0.0025 & 0.2937 \\
\hline Target R\&D to market value & 2559 & 0.0256 & 0.0597 & 0.0000 & 0.9425 \\
\hline Target R\&D to sales & 2559 & 0.3285 & 6.0714 & 0.0000 & 297.6081 \\
\hline Target R\&D growth & 2559 & 0.1280 & 0.5871 & -1.0000 & 12.2384 \\
\hline Target organizational flexibility & 2559 & 0.2587 & 0.9092 & 0.0000 & 39.6375 \\
\hline Target financial flexibility (leverage) & 2559 & 0.5826 & 0.2918 & 0.0021 & 4.2037 \\
\hline $\begin{array}{l}\text { Target financial flexibility (cashflow } \\
\text { coverage) }\end{array}$ & 2559 & 0.1091 & 0.5621 & -5.5793 & 4.5028 \\
\hline Target sales growth & 2559 & 1.9053 & 56.6573 & -0.7758 & $2,680.6800$ \\
\hline Bidder R\&D to market value & 2559 & 0.1368 & 0.9937 & 0.0000 & 19.9248 \\
\hline Bidder R\&D to sales & 2559 & 0.0379 & 0.1377 & 0.0000 & 3.6269 \\
\hline Bidder R\&D growth & 2559 & 0.1023 & 1.2814 & -1.0000 & 62.3304 \\
\hline
\end{tabular}

\subsubsection{Summary statistics of synergy effect variables}

Table 3 illustrates the descriptive statistics of synergy effect variables. The mean of industry relatedness variable is 0.7440 , indicating that there are $74.40 \%$ deals that bidder and target are in the same industry. Financial synergy variable ranges from -898.5651 to 909.0139 with the mean of -0.3991 . The means of relative size measured as the total sales one year before the announcement, total assets one fiscal year before the announcement, and market value four weeks before announcement are $0.5243,0.0023$, and 0.5962 respectively. 
Table 3: Summary statistics of synergy effect variables

\begin{tabular}{|l|c|c|c|c|c|}
\hline Variable & Observations & Mean & Std. Dev. & Min & Max \\
\hline Industry relatedness & 2559 & 0.7440 & 0.4365 & 0.0000 & 1.0000 \\
\hline Financial synergy & 2559 & -0.3991 & 32.1611 & -898.5651 & 909.0139 \\
\hline Relative size (sales) & 2559 & 0.5243 & 1.2768 & 0.0000 & 40.0654 \\
\hline Relative size (assets) & 2559 & 0.0023 & 0.0132 & -0.0008 & 0.6070 \\
\hline Relative size (market value) & 2559 & 0.5962 & 5.6277 & 0.0000 & 209.6162 \\
\hline
\end{tabular}

\subsubsection{Summary statistics of deal characteristic variables}

Table 4 presents the summary statistics for deal characteristics variable. Each variable has 2559 observations. The number of competing bids, methods of payment, tender offer, the merger of equals, and hostile acquisition variables are dummy variables, which take the value of 1 or 0 . The mean of the number of competing bids, tender offer, the merger of equal, are $0.0492,0.2384$, and 0.0109 respectively. These numbers indicate that $4.92 \%$ deals have competing bids, $23.84 \%$ observations that are tender offers, and 1.09\% deals that have mergers of equals. Method of payment includes pure cash, pure stock, mix of cash and stock, and other methods. As can be seen in table $4,40.21 \%, 28.96 \%, 10.75 \%$ and $20.09 \%$ of observation are pure cash deals, pure stock deals, mix deals, and other deals respectively. Hostile acquisition variable is a dummy variable, which equals 1 if the deal is hostile deal and 0 if the deal is a friendly deal. The mean of hostile acquisition variable is 0.0152 , which means $1.52 \%$ of deals are hostile deals. The deal size is the $\log$ of acquisition transaction value, which ranges from 2.0000 to 5.2168. The mean and standard deviation is deal size variable are 2.7958 and 0.5893 respectively. Number of day to effective ranges from 0 to 5,270 days with the average of 161 days. 
Table 4: Summary statistics of deal characteristic variables

\begin{tabular}{|l|c|c|c|c|c|}
\hline Variable & Observations & Mean & Std. Dev. & Min & Max \\
\hline Number of competing bids & 2559 & 0.0492 & 0.2164 & 0.0000 & 1.0000 \\
\hline Method of payment (cash) & 2559 & 0.4021 & 0.4904 & 0.0000 & 1.0000 \\
\hline Method of payment (stock) & 2559 & 0.2896 & 0.4536 & 0.0000 & 1.0000 \\
\hline Method of payment (mix) & 2559 & 0.1075 & 0.3098 & 0.0000 & 1.0000 \\
\hline Method of payment (other) & 2559 & 0.2009 & 0.4007 & 0.0000 & 1.0000 \\
\hline Tender offer & 2559 & 0.2384 & 0.4262 & 0.0000 & 1.0000 \\
\hline Merger of equal & 2559 & 0.0109 & 0.1040 & 0.0000 & 1.0000 \\
\hline Deal size & 2559 & 2.7958 & 0.5893 & 2.0000 & 5.2168 \\
\hline Hostile acquisition & 2559 & 0.0152 & 0.1225 & 0.0000 & 1.0000 \\
\hline Number of day to effective & 2559 & 161.0000 & 245.8819 & 0.0000 & $5,270.0000$ \\
\hline
\end{tabular}

\subsubsection{Summary statistics of target firm characteristic variables}

Table 5 depicts the descriptive statistics of target firm's characteristic variables. Target resistance to takeover variable is the dummy variable, which takes a value of 1 if the target has the poison pill and 0 if otherwise. The mean of target resistance to takeover variable is 0.0078 , which means $0.78 \%$ of the targets have poison pills. Target firm business risk variable ranges from 0.1655 to 0.0898 with a mean of 0.0135 . Target firm size measured as log of sales, assets, and market value have the means of $2.6026,2.9322$, and 2.8276 respectively. Target market to book ratio ranges from -798.0409 to 3,425.4540 with an average of 4.1111. The means of target ROA, target ROE, target operating cash flow, target financial independence, and target debt to equity are $0.8105,0.4825,0.1683,-0.1113$, and 3.3319 respectively. 
Table 5: Summary statistics of target firm characteristic variables

\begin{tabular}{|l|c|c|c|c|c|}
\hline Variable & Observations & Mean & Std. Dev. & Min & Max \\
\hline Target resistance to takeover & 2559 & 0.0078 & 0.0881 & 0.0000 & 1.0000 \\
\hline Target business risk & 2559 & 0.0135 & 0.0146 & -0.1655 & 0.0898 \\
\hline Target firm size (sales) & 2559 & 2.6026 & 0.8232 & -1.6576 & 5.1769 \\
\hline Target firm size (assets) & 2559 & 2.9322 & 0.8132 & -0.1918 & 6.3551 \\
\hline Target firm size (market value) & 2559 & 2.8278 & 0.7175 & 0.7357 & 5.4042 \\
\hline Target market to book ratio & 2559 & 4.1111 & 74.5279 & -798.0409 & $3,425.4540$ \\
\hline Target ROA & 2559 & 0.8105 & 19.3553 & -546.0343 & 93.3066 \\
\hline Target ROE & 2559 & 0.4825 & 267.8504 & $-6,250.8290$ & $7,154.8970$ \\
\hline Target operating cashflow & 2559 & 0.1683 & 17.3196 & -316.7297 & 811.1364 \\
\hline Target financial independence & 2559 & -0.1113 & 0.2335 & -2.5588 & 0.8393 \\
\hline Target debt to equity & 2559 & 3.3319 & 26.8739 & -889.1974 & 908.8473 \\
\hline
\end{tabular}

\subsubsection{Summary statistics of bidder firm characteristic variables}

Table 6 presents the summary statistics of bidder's characteristic variables. The public bidder variable is dummy variable with the value of 1 for public acquirers and 0 for private acquirers. The mean of public bidder variable is 0.9957 , which means 99.57 percentage of deals have public acquirers. The means of target shares owned by bidder before M\&A announcement ranges from $0 \%$ to $93.80 \%$ with an average of $1.66 \%$. Target shares owned by bidder after M\&A announcement ranges from $0 \%$ to $100 \%$ with a mean of $83.88 \%$.

Table 6: Summary statistics of bidder firm characteristic variables

\begin{tabular}{|l|c|c|c|c|c|}
\hline Variable & Observations & Mean & Std. Dev. & Min & Max \\
\hline Public bidder & 2559 & 0.9957 & 0.0654 & 0.0000 & 1.0000 \\
\hline $\begin{array}{l}\text { Target shares owned by } \\
\text { bidder before M\&A }\end{array}$ & 2559 & 0.0166 & 0.0963 & 0.0000 & 0.9380 \\
\hline $\begin{array}{l}\text { Target shares owned by } \\
\text { bidder after M\&A }\end{array}$ & 2559 & 0.8388 & 0.3420 & 0.0000 & 1.0000 \\
\hline
\end{tabular}




\subsection{Check for potential problems in multiple regression models}

\subsubsection{Heteroskedasticity test}

In the multiple regression, we assume that the residuals are homogeneous. Heteroskedasticity problem can affect the results of our regression models, so we Breusch-Pagan test to detect the heteroskedasticity problem. In this test, the null hypothesis is that residuals of the regressions are homogeneous. The table 7 shows that p-value of the test is 0.000 , which is less than 0.01 . Thus, we reject the null hypothesis of the error is homogeneous at $1 \%$ significant level. Specifically, the residuals are not homogeneous. To address this drawback, we run regressions with robust.

Table 7: Heteroskedasticity test

\begin{tabular}{|c|}
\hline Breusch-Pagan / Cook-Weisberg test for heteroskedasticity \\
\hline Ho: Constant variance \\
\hline chi2(1) $=471.90$ \\
\hline Prob $>$ chi $2=0.0000$ \\
\hline
\end{tabular}

\subsubsection{Multicollinear test}

The assumption for the multiple regression is that the independent variables are not perfectly multicollinear. So, I use VIF (Variance Inflation Factor) test to check for the multicollinear of our models. In this test, if the VIF value is higher 10 or the 1/VIF value is lower than 0.1 , the regression has the multicollinear problem. As can be seen in table 8 , all our variables have VIF value less than 10. Thus, there is no multicollinear problem in our models. 
Table 8: Multicollinear test

\begin{tabular}{|l|c|c|}
\hline & VIF & 1/VIF \\
\hline Target business risk & 7.27 & 0.137622 \\
\hline Target financial flexibility (leverage) & 5.27 & 0.189608 \\
\hline Target firm size (sales) & 3.84 & 0.260273 \\
\hline Target debt to equity & 3.49 & 0.286258 \\
\hline Target idiosyncratic volatility & 3.15 & 0.317377 \\
\hline Financial synergy & 3.09 & 0.32381 \\
\hline Target shares owned by bidder after M\&A & 2.58 & 0.387014 \\
\hline Deal size & 2.38 & 0.420539 \\
\hline Cash & 1.81 & 0.551059 \\
\hline Target financial independence & 1.75 & 0.572288 \\
\hline Target ROA & 1.66 & 0.601018 \\
\hline Target market to book ratio & 1.62 & 0.61801 \\
\hline Stock & 1.56 & 0.639591 \\
\hline Target financial flexibility (cashflow coverage) & 1.52 & 0.658062 \\
\hline Bidder idiosyncratic volatility & 1.42 & 0.703814 \\
\hline Target ROE & 1.39 & 0.721917 \\
\hline Tender offer & 1.38 & 0.723635 \\
\hline Target R\&D to market value & 1.34 & 0.745999 \\
\hline Hostile acquisition & 1.29 & 0.77375 \\
\hline Target R\&D growth & 1.24 & 0.805796 \\
\hline Target resistance to takeover & 1.23 & 0.811393 \\
\hline Number of day to effective & 1.16 & 0.864677 \\
\hline Industry relatedness & 1.14 & 0.879261 \\
\hline Target organizational flexibility & 1.13 & 0.886618 \\
\hline Target R\&D to sales & 1.12 & 0.894474 \\
\hline Target R\&D growth & 1.09 & 0.918222 \\
\hline Number of competing bids & 1.08 & 0.92557 \\
\hline Relative size (sales) & 1.08 & 0.927806 \\
\hline Target shares owned by bidder before M\&A & 1.05 & 0.953225 \\
\hline Merger of equal & 1.05 & 0.954321 \\
\hline Target operating cashflow & 1.04 & 0.960863 \\
\hline Bidder R\&D to market value & 1.04 & 0.962526 \\
\hline Bidder R\&D to sales & 1.04 & 0.964978 \\
\hline Bidder R\&D growth & 1.02 & 0.977105 \\
\hline Public bidder & 1.01 & 0.991856 \\
\hline Mean VIF & 1.87 & \\
\hline & & \\
\hline
\end{tabular}




\subsection{Regression Analysis}

In this section, we examine the effect of stock return volatility and real option variables on M\&A premiums, while controlling for deal characteristics, target firm characteristics, and bidder firm characteristics. There are two measures of M\&A premiums, which are total premiums and S\&P 500 adjusted premiums. We used M\&A premiums after being adjusted for S\&P 500 in our main regressions. The total M\&A premiums are used in robustness test.

\subsubsection{Regressions without interaction terms between volatility and real option variables}

We test $\mathrm{H} 1$ by studying the impact of volatility on M\&A premiums. We first run the regressions, in which M\&A premiums is the dependent variable and stock return volatility of bidder and target, real option variables of bidder and target, and control variables are the independent variables. Then, we use the same model for pure cash, pure stock, and mix samples. There are three measures of firm size, which are sales, assets, and market value. We also run the regressions using three different measures of firm size to compare the results. Two different measures of volatility are also tested. The results are illustrated in table 8 for idiosyncratic volatility and table 9 for total volatility.

\section{- Regressions using idiosyncratic volatility}

Regressions (1), (2), (3) and (4) of table 8 report the results for S\&P 500 adjusted M\&A by using sales as the measure of firm size. In regressions (5), (6), (7) and (8), we replace sales with assets for size measurement. We use market value as the measure of size in regressions (9), (10), (11) and (12). In regression (1), (5), and (9), we use full sample. Pure cash sample are used in regression (2), (6), and (10). We run the regressions in pure stock sample in the model (3), (7), and 
(11). In the model (4), (8), (12), we use the sample, which includes the deals with a mix of cash and stock.

In the regression (1) of table 8, the estimated coefficient of idiosyncratic volatility of targets is positive at 5.657 with $5 \%$ level of significance. However, the estimated coefficient of target idiosyncratic volatility is insignificant in the regression (5) and (9). These results show that the idiosyncratic volatility of target firms is significantly positively related to M\&A premiums in full sample only when we use sales as the measure of size. As can be seen in the regression (2), (6), and (10), idiosyncratic volatilitíe of target firms have positive coefficients that are significant at $0.1 \%$ level. In cash deals, the positive relationship between the idiosyncratic volatility of targets and acquisition premiums is consistent in all three measures of firm size. As shown in regression (3), (4), (7), (8), (11) and (12), the coefficients of target idiosyncratic volatility are insignificant in stock deals and mix deals.

In the regression (2), (6), and (10) of table 8, the coefficients of the bidder idiosyncratic volatility are negative at $0.1 \%$ level of significance. Furthermore, as can be seen in regression (4), idiosyncratic volatility of bidders has a positive coefficient that is significant at $0.1 \%$ level. So, the bidder idiosyncratic volatility has the negative relationship with M\&A premiums in cash deals, and this relationship is significant for all three measures of firm size. The acquisition premiums and bidder idiosyncratic volatility have a positive relationship in mix deals.

As regards the real option variables of targets, in table 8, the estimated coefficients of target R\&D to market value are positive at $0.1 \%$ level of significant not only in full sample but also in pure stock deals sample and pure cash deals sample. The results are consistent with all three kinds of firm size measurement for the full sample and cash deals sample. The positive relationship of 
target $R \& D$ to market value and $M \& A$ premiums in stock samples is significant when we measure firm size as sales and assets, yet insignificant when we measure firm size as market value. The $R \& D$ to sales of target firms is only significantly negatively correlated with M\&A premiums in stock deals. The result applies when we measure firm size as sales and market value. As shown in regression (6), (7), and (8) of table 8 , the coefficients of target financial flexibility measured as leverage ratio are significantly positive in pure stock deals, pure cash deals, and mix deals. Yet, the coefficient of target financial flexibility (leverage) is insignificant in full sample. The regression (5) and (8) depict that target financial flexibility measured as cash flow coverage is significantly negatively correlated with acquisition premiums when we measure firm size as assets or market value. As can be seen in regression (1), (5), and (9), in full sample, target sales growth variables have negative coefficients that are significant at $1 \%$ level, $0.1 \%$ level, and $5 \%$ level for sales, assets, and market value measures of firm size, respectively. The results indicate that target sales growth is negatively correlated with M\&A premiums in full sample.

Concerning the real option variables of bidders, neither coefficients of $R \& D$ to market value, coefficients of $R \& D$ to sales, nor coefficients of $R \& D$ growth rate of acquiring firm are significant when firm size is measured as sales or market value. However, as can be seen in regression (6) of table 8, when we use assets as the measure of firm size, bidder R\&D to market value has a positive coefficient that is significant at $5 \%$ level. A bidder with higher R\&D to market value realize higher M\&A premiums in cash deals.

Among the control variables, there are four categories, including synergy between bidder and target, deal characteristics, targets characteristics, and bidder characteristics. Synergy variables contain industry relatedness, financial synergy, and relative size. As can be seen in table 
8, the coefficients of industry relatedness variables are insignificant. So, there is no relationship between industry relatedness and acquisition premiums. In the regression (4) and (8) of table 8 , financial synergy has positive coefficients that are significant at 5\% level. However, as can be seen in regression (6), the estimated coefficient of financial synergy is negative at $5 \%$ level of significance. The results indicate that when we measure firm size as sales, the higher financial synergy is associated with higher M\&A premiums in mix deals. When firm size is measured as assets, the financial synergy and acquisition premiums have the positive relationship in mix deals and negative relationship in cash deals. The results are insignificant when we measure size as market value. As can be seen in the regression (2), (8), (9), and (10) of table 8, the estimated coefficients of relative size are significantly negative.

Deal characteristics variables include number of competing bids, methods of payment, tender offer, the merger of equal, deal size, hostile acquisition, and number of day to effective. Regression (1), (2), (5), (6), (7), (8), and (9) of table 8 show that the number of competing for bid and tender offer have significantly positive coefficients. So, acquisition premiums are higher in the deal what have more than one competing bidder and in the tender offer deal. The estimated coefficient of deal size is positive and significant in full sample, stock sample, and cash sample, indicating that the larger of the deal size, the higher of M\&A premiums. Merger of equal variables have negative coefficients that are significant at $0.1 \%$ level. Thus, the acquisition premiums are lower in the merger of equals deal. The regression (8) of table 8 indicates that the coefficient of the hostile acquisition variable is positive and significant at $5 \%$ level in mix deals sample. The M\&A premiums are higher in the mix deals and hostile takeover deals. As can be seen in the regression (7) and (11) of table 8, the coefficients of the number of days to effective variables are 
positive at $5 \%$ level of significance. The more days to effective, the higher acquisition premiums. The method of payment variable is insignificant.

Target firm's characteristics variables contain target resistance to takeover, target business risk, target firm size, target market to book ratio, target ROA, target ROE, target operating cash flow, target financial independence, and target debt to equity. As can be seen in the regression (4), (8), and (12) of table 8, the coefficients on target resistance to takeover variable are negative and significant at $1 \%$ level in all three regressions. The results indicate that in the mix of stock and cash deals, bidders pay lower M\&A premiums when target firms have the poison pills. The regression (7), and (11) of table 8 show the positive coefficients of target business risk variables, which are significant at 5\% level. The higher target business risk, the higher acquisition premiums. The estimated coefficients of target firm size are significantly negative when we measure firm size as sales, assets, and market value, indicating bidder firms pay more M\&A premiums to acquire the target firm with small size. As shown in the regression (1), (5), and (7), target ROA variable has a positive coefficient that significant at $5 \%$ level. The higher target ROA, the higher acquisition premiums in full sample and stock sample. In contrast, the coefficient of target ROE is negative at $5 \%$ level of significance. The higher ROE of target firms, the lower M\&A premiums in cash deals sample. In the regression (7) and (11) of table 8, the target operating cash flow variable coefficient is positive at $0.1 \%$ significant level. So, in stock deals sample, bidder firms pay more acquisition premiums for the targets that have high operating cash flow. As can be seen in the regression (2), (6), and (10) of table 8 , the estimated coefficient of target debt to equity ratio is significantly positive. However, the coefficient of target debt to equity ratio is negative in the regression (4) of table 8 . Thus, higher target debt to equity, higher M\&A premiums in cash deal. In mix deal, the target debt to equity ratio and acquisition premiums has the negative relationship. 
Bidder firm's characteristics variables include public bidder and target shares owned by bidder before and after M\&A announcement. The regression (4), (5), 8), (9), and (12) of table 8 show that the coefficients of public bidder variables are significantly positive. The acquisition premiums are higher when the acquirers are the public firms in full sample and mix sample. A critical difference in the results when using sales, assets, and market value as the measures of firm size is the results of the percentage of target shared owned by the bidder before and after acquisition announcement variables. As can be seen in the regression (4), (9), (10), and (11) of the table 8 , the coefficient of the percentage of target shares owned by bidder prior to acquisition is negative when we measure size as sales, yet it is positive when size is measured as market value. In the regression (1), (2), (5), (6), (9), and (11) of the table 8, when we use sales and assets as the measure of firm size, the estimated coefficients of target shared owned by the bidder after M\&A are positive at $0.1 \%$ level of significant. However, when we measure firm size as market value, the coefficients are negative and significant at $0.1 \%$ level. The results when firm size is estimated as market value are quite biased. Because we use one month before acquisition to estimate the M\&A premiums and market value, endogeneity problem may arise. Thus, using ordinary least square to run the regression with market value measure may not produce the satisfactory results. Two-stage least square should be used to run the regression with market value measure. In this research paper, we report the results with sales and market value measurement as our primary results. The results with the market value measured as firm size are used to confirm. So, in this case, the target shared owned by the bidder before acquisition and M\&A premiums have a negative relationship. The target shared owned by the bidder after M\&A announcement variable is significantly positively correlated with acquisition premiums. 


\section{- Regressions using total volatility}

As can be seen in table 9, the results when we use total return volatility instead of idiosyncratic volatility are almost the same as the results for idiosyncratic volatility. There is no significant change. In idiosyncratic volatility results, the target financial flexibility (leverage) variables are not significant when we use sales to measure firm size. However, they are significant when we use total volatility. Also, the estimated coefficient of the hostile variable is not significant when we use idiosyncratic volatility is now positive and significant at $5 \%$ level in total volatility model. 
Table 8: Regression results of S\&P adjusted M\&A premiums, idiosyncratic volatility, and real option variables

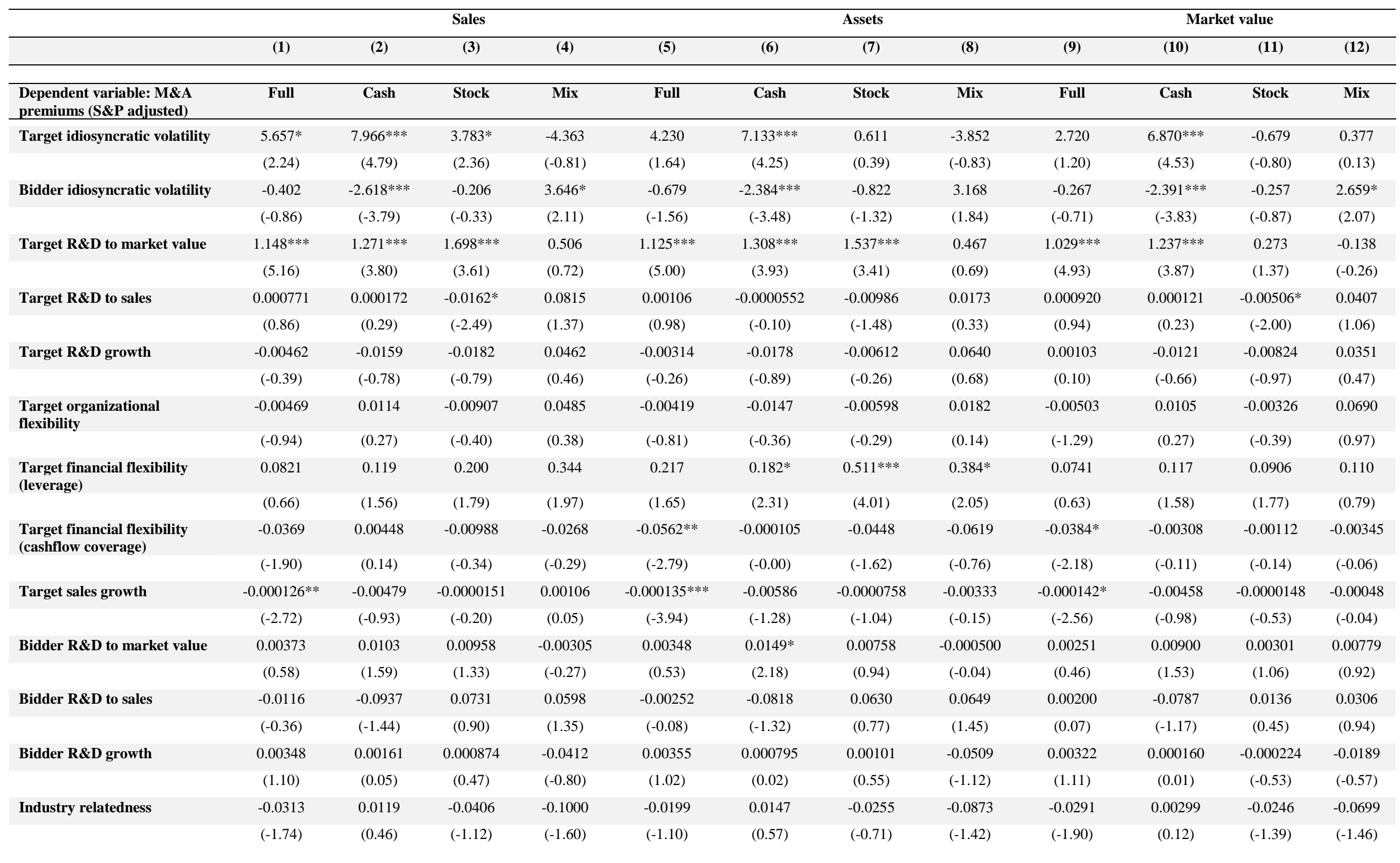




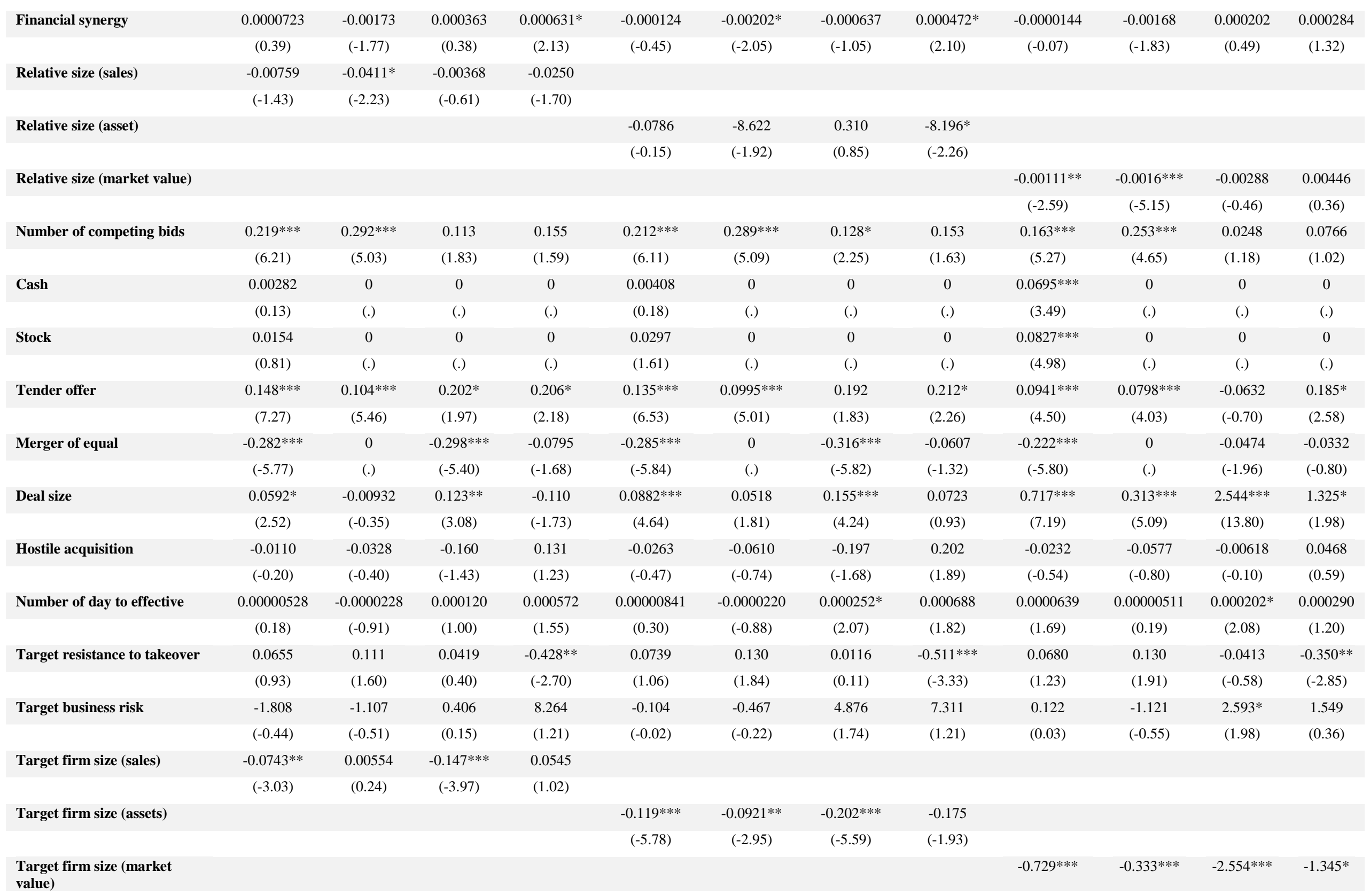




\begin{tabular}{|c|c|c|c|c|c|c|c|c|c|c|c|c|}
\hline & & & & & & & & & $(-7.33)$ & $(-5.41)$ & $(-13.75)$ & $(-2.03)$ \\
\hline \multirow[t]{2}{*}{ Target market to book ratio } & $-0.000249 * *$ & $-0.00226^{*}$ & $-0.000721^{*}$ & 0.000250 & $-0.000273 * *$ & $-0.00330 * *$ & $-0.000633^{*}$ & 0.000381 & $-0.000187 *$ & $-0.00173^{*}$ & $-0.0004 * * *$ & 0.000160 \\
\hline & $(-2.68)$ & $(-2.36)$ & $(-2.44)$ & $(1.07)$ & $(-2.93)$ & $(-2.63)$ & $(-2.06)$ & (1.44) & $(-2.07)$ & $(-2.30)$ & $(-3.42)$ & $(1.15)$ \\
\hline \multirow[t]{2}{*}{ Target ROA } & $0.000842 *$ & 0.0000332 & $0.00192 *$ & 0.00199 & $0.00104 *$ & -0.000106 & $0.00364 * * *$ & -0.000447 & 0.000452 & 0.000154 & -0.000479 & -0.00017 \\
\hline & $(2.17)$ & $(0.07)$ & $(1.98)$ & $(0.44)$ & $(2.48)$ & $(-0.20)$ & $(3.33)$ & $(-0.09)$ & $(1.08)$ & $(0.36)$ & $(-1.02)$ & $(-0.05)$ \\
\hline \multirow[t]{2}{*}{ Target ROE } & 0.00000695 & -0.0000164 & 0.000185 & 0.0000476 & 0.00000321 & $-0.0000237^{*}$ & -0.00000553 & 0.000314 & -0.000000632 & -0.0000146 & -0.0000604 & 0.000199 \\
\hline & $(0.24)$ & $(-0.85)$ & $(1.09)$ & $(0.09)$ & $(0.10)$ & $(-2.38)$ & $(-0.03)$ & $(0.57)$ & $(-0.02)$ & $(-0.75)$ & $(-0.86)$ & $(0.53)$ \\
\hline \multirow[t]{2}{*}{ Target operating cashflow } & -0.000793 & $-0.00930^{*}$ & 0.000153 & -0.00316 & -0.000547 & -0.00767 & $0.000780 * * *$ & -0.00662 & -0.000561 & $-0.00841^{*}$ & $\begin{array}{c}0.000300^{* *} \\
*\end{array}$ & -0.00393 \\
\hline & $(-0.54)$ & $(-2.07)$ & $(0.81)$ & $(-0.75)$ & $(-0.35)$ & $(-1.70)$ & $(8.14)$ & $(-1.72)$ & $(-0.39)$ & $(-2.08)$ & $(4.89)$ & $(-1.41)$ \\
\hline \multirow[t]{2}{*}{ Target financial independence } & 0.0119 & -0.0418 & -0.0697 & -0.0714 & 0.0220 & -0.0187 & -0.0597 & 0.00137 & -0.0129 & -0.0288 & -0.0355 & 0.00289 \\
\hline & $(0.23)$ & $(-0.77)$ & $(-0.91)$ & $(-0.52)$ & $(0.44)$ & $(-0.36)$ & $(-0.79)$ & $(0.01)$ & $(-0.29)$ & $(-0.56)$ & $(-1.13)$ & $(0.03)$ \\
\hline \multirow[t]{2}{*}{ Target debt to equity } & -0.0000168 & $0.00306^{*}$ & -0.00141 & $-0.00663 * *$ & 0.000345 & $0.00543^{* * *}$ & 0.00109 & -0.00287 & 0.0000953 & $0.00304^{*}$ & 0.000332 & -0.00213 \\
\hline & $(-0.06)$ & $(2.11)$ & $(-1.00)$ & $(-3.12)$ & $(1.04)$ & $(3.67)$ & $(0.75)$ & $(-1.22)$ & $(0.35)$ & $(2.13)$ & $(0.59)$ & $(-1.10)$ \\
\hline \multirow[t]{2}{*}{ Public bidder } & 0.114 & 0.0934 & 0.109 & $0.220 *$ & $0.137 *$ & 0.0825 & 0.112 & $0.367 * *$ & $0.110^{*}$ & 0.0951 & 0.0288 & $0.467 * * *$ \\
\hline & $(1.72)$ & $(0.67)$ & $(1.70)$ & $(2.27)$ & $(2.20)$ & $(0.61)$ & $(1.67)$ & $(3.20)$ & (1.99) & $(0.80)$ & $(0.36)$ & $(3.72)$ \\
\hline \multirow{2}{*}{$\begin{array}{l}\text { Target shares owned by } \\
\text { bidder before M\&A }\end{array}$} & -0.0552 & -0.0724 & -0.0484 & $-0.305^{*}$ & -0.00349 & 0.00336 & -0.00377 & -0.207 & $0.521 * * *$ & $0.205^{*}$ & $2.186^{* * * *}$ & 1.016 \\
\hline & $(-0.84)$ & $(-0.75)$ & $(-0.43)$ & $(-2.29)$ & $(-0.05)$ & $(0.03)$ & $(-0.03)$ & $(-1.53)$ & $(5.10)$ & $(2.04)$ & $(9.33)$ & $(1.58)$ \\
\hline \multirow{2}{*}{$\begin{array}{l}\text { Target shares owned by } \\
\text { bidder after M\&A }\end{array}$} & $0.244 * * *$ & $0.328 * * *$ & -0.167 & -0.144 & $0.216^{* * *}$ & $0.248 * * *$ & -0.122 & -0.163 & $-0.596 * * *$ & -0.0763 & $-2.981 * * *$ & -0.164 \\
\hline & $(6.12)$ & $(8.45)$ & $(-0.93)$ & $(-0.79)$ & $(6.94)$ & $(5.88)$ & $(-0.71)$ & $(-0.93)$ & $(-4.23)$ & $(-0.89)$ & $(-9.82)$ & $(-1.18)$ \\
\hline \multirow[t]{2}{*}{ _cons } & -0.164 & -0.283 & 0.175 & 0.117 & -0.158 & -0.120 & 0.0869 & 0.102 & $0.575 * * *$ & 0.140 & $2.865 * * *$ & -0.280 \\
\hline & $(-1.39)$ & $(-1.70)$ & $(0.90)$ & $(0.49)$ & $(-1.50)$ & $(-0.70)$ & $(0.46)$ & $(0.41)$ & $(3.52)$ & $(0.85)$ & $(9.65)$ & $(-1.22)$ \\
\hline $\mathbf{N}$ & 2559 & 1029 & 741 & 275 & 2559 & 1029 & 741 & 275 & 2559 & 1029 & 741 & 275 \\
\hline adj.R-sq & 0.265 & 0.506 & 0.12 & 0.33 & 0.272 & 0.512 & 0.141 & 0.351 & 0.386 & 0.538 & 0.763 & 0.569 \\
\hline $\begin{array}{l}t \text { statistics in parentheses } \\
* \mathbf{p}<0.05, * * \mathbf{p}<0.01, * * * \mathbf{p}<0.00\end{array}$ & & & & & & & & & & & & \\
\hline
\end{tabular}


Table 9: Regression results of S\&P adjusted M\&A premiums, total volatility, and real option variables

\begin{tabular}{|c|c|c|c|c|c|c|c|c|c|c|c|c|}
\hline & \multicolumn{4}{|c|}{ Sales } & \multicolumn{4}{|c|}{ Assets } & \multicolumn{4}{|c|}{ Market value } \\
\hline & (1) & (2) & (3) & (4) & (5) & (6) & (7) & (8) & (9) & (10) & (11) & (12) \\
\hline $\begin{array}{l}\text { Dependent variable: } M \& A \\
\text { premiums (S\&P adjusted) }\end{array}$ & Full & Cash & Stock & Mix & Full & Cash & Stock & Mix & Full & Cash & Stock & Mix \\
\hline \multirow[t]{2}{*}{ Target total volatility } & $5.396^{*}$ & $8.316^{* * *}$ & 2.712 & -5.651 & 4.076 & $7.609 * * *$ & -0.155 & -4.414 & 2.727 & $7.358 * * *$ & -0.807 & 0.497 \\
\hline & $(2.03)$ & $(4.48)$ & $(1.75)$ & $(-1.03)$ & $(1.52)$ & $(4.01)$ & $(-0.11)$ & $(-0.95)$ & (1.16) & $(4.33)$ & $(-1.04)$ & $(0.16)$ \\
\hline \multirow[t]{2}{*}{ Bidder total volatility } & -0.431 & $-2.405^{* * *}$ & -0.296 & $3.134^{*}$ & -0.641 & $-2.178^{* *}$ & -0.736 & 2.842 & -0.233 & $-2.178 * * *$ & -0.268 & 2.245 \\
\hline & $(-0.97)$ & $(-3.53)$ & $(-0.49)$ & $(1.98)$ & $(-1.50)$ & $(-3.17)$ & $(-1.23)$ & $(1.78)$ & $(-0.65)$ & $(-3.54)$ & $(-1.07)$ & $(1.92)$ \\
\hline \multirow[t]{2}{*}{ Target R\&D to market value } & $1.136^{* * *}$ & $1.219 * * *$ & $1.709 * * *$ & 0.520 & $1.116^{* * *}$ & $1.256^{* * *}$ & $1.550 * * *$ & 0.469 & $1.019^{* * *}$ & $1.186^{* * *}$ & 0.278 & -0.0981 \\
\hline & $(5.04)$ & $(3.56)$ & (3.63) & $(0.76)$ & $(4.88)$ & (3.69) & $(3.46)$ & $(0.71)$ & $(4.82)$ & $(3.62)$ & $(1.40)$ & $(-0.19)$ \\
\hline \multirow[t]{2}{*}{ Target $R \& D$ to sales } & 0.000805 & 0.000200 & $-0.0161^{*}$ & 0.0844 & 0.00108 & -0.0000316 & -0.00996 & 0.0158 & 0.000941 & 0.000146 & $-0.00515^{*}$ & 0.0375 \\
\hline & $(0.91)$ & $(0.34)$ & $(-2.43)$ & $(1.40)$ & $(1.00)$ & $(-0.06)$ & $(-1.48)$ & $(0.30)$ & $(0.97)$ & $(0.27)$ & $(-2.01)$ & $(0.98)$ \\
\hline \multirow[t]{2}{*}{ Target $R \& D$ growth } & -0.00409 & -0.0167 & -0.0174 & 0.0435 & -0.00290 & -0.0185 & -0.00564 & 0.0593 & 0.00118 & -0.0129 & -0.00804 & 0.0355 \\
\hline & $(-0.34)$ & $(-0.83)$ & $(-0.76)$ & $(0.43)$ & $(-0.24)$ & $(-0.94)$ & $(-0.24)$ & $(0.63)$ & $(0.12)$ & $(-0.71)$ & $(-0.94)$ & $(0.47)$ \\
\hline Target organizational flexibility & $(-0.94)$ & $(0.29)$ & $(-0.38)$ & $(0.40)$ & $(-0.82)$ & $(-0.37)$ & $(-0.31)$ & $(0.12)$ & $(-1.29)$ & $(0.28)$ & $(-0.40)$ & $(1.00)$ \\
\hline \multirow[t]{2}{*}{$\begin{array}{l}\text { Target financial flexibility } \\
\text { (leverage) }\end{array}$} & 0.0767 & 0.0888 & $0.231 *$ & $0.397 *$ & 0.214 & 0.147 & $0.545^{* * * *}$ & $0.410^{*}$ & 0.0637 & 0.0816 & 0.101 & 0.0877 \\
\hline & $(0.56)$ & $(1.07)$ & $(2.01)$ & $(1.99)$ & $(1.51)$ & $(1.72)$ & $(4.30)$ & $(2.07)$ & $(0.50)$ & $(1.02)$ & $(1.90)$ & $(0.54)$ \\
\hline \multirow[t]{2}{*}{$\begin{array}{l}\text { Target financial flexibility } \\
\text { (cashflow coverage) }\end{array}$} & -0.0370 & -0.000210 & -0.00777 & -0.0252 & $-0.0574 * *$ & -0.00507 & -0.0448 & -0.0617 & $-0.0392^{*}$ & -0.00791 & -0.000892 & -0.00661 \\
\hline & $(-1.89)$ & $(-0.01)$ & $(-0.27)$ & $(-0.27)$ & $(-2.81)$ & $(-0.17)$ & $(-1.63)$ & $(-0.77)$ & $(-2.20)$ & $(-0.27)$ & $(-0.11)$ & $(-0.11)$ \\
\hline \multirow[t]{2}{*}{ Target sales growth } & $-0.000128^{* *}$ & -0.00497 & -0.0000150 & 0.00293 & $-0.000137 * * *$ & -0.00611 & -0.0000751 & -0.00229 & $-0.000144 * *$ & -0.00477 & -0.0000143 & 0.00166 \\
\hline & $(-2.79)$ & $(-1.06)$ & $(-0.20)$ & $(0.15)$ & $(-3.98)$ & $(-1.41)$ & $(-1.03)$ & $(-0.11)$ & $(-2.60)$ & $(-1.11)$ & $(-0.51)$ & $(0.14)$ \\
\hline \multirow[t]{2}{*}{ Bidder R\&D to market value } & 0.00276 & 0.00938 & 0.00919 & -0.00298 & 0.00278 & $0.0142^{*}$ & 0.00797 & -0.00048 & 0.00203 & 0.00825 & 0.00334 & 0.00711 \\
\hline & $(0.42)$ & $(1.43)$ & $(1.22)$ & $(-0.26)$ & $(0.42)$ & $(2.04)$ & $(0.99)$ & $(-0.04)$ & $(0.37)$ & $(1.38)$ & $(1.21)$ & $(0.85)$ \\
\hline \multirow[t]{2}{*}{ Bidder R\&D to sales } & -0.0122 & -0.0965 & 0.0742 & 0.0576 & -0.00240 & -0.0838 & 0.0629 & 0.0640 & 0.00208 & -0.0807 & 0.0132 & 0.0300 \\
\hline & $(-0.37)$ & $(-1.45)$ & $(0.91)$ & $(1.34)$ & $(-0.07)$ & $(-1.33)$ & $(0.77)$ & $(1.46)$ & $(0.08)$ & $(-1.17)$ & $(0.44)$ & $(0.93)$ \\
\hline Bidder R\&D growth & 0.00374 & 0.000842 & 0.00102 & -0.0386 & 0.00370 & -0.000248 & 0.000996 & -0.0512 & 0.00334 & -0.000931 & -0.000246 & -0.0193 \\
\hline Industry relatedness & $(-1.72)$ & $(0.44)$ & $(-1.12)$ & $(-1.58)$ & $(-1.07)$ & $(0.58)$ & $(-0.72)$ & $(-1.41)$ & $(-1.86)$ & $(0.11)$ & $(-1.40)$ & $(-1.39)$ \\
\hline
\end{tabular}




\begin{tabular}{|c|c|c|c|c|c|c|c|c|c|c|c|c|}
\hline \multirow[t]{2}{*}{ Financial synergy } & 0.0000817 & -0.00167 & 0.000463 & $0.000622 *$ & -0.000126 & -0.00197 & -0.000582 & 0.000450 & -0.0000132 & -0.00162 & 0.000214 & 0.000278 \\
\hline & $(0.47)$ & $(-1.66)$ & $(0.47)$ & $(2.07)$ & $(-0.47)$ & $(-1.93)$ & $(-0.97)$ & $(1.95)$ & $(-0.06)$ & $(-1.72)$ & $(0.52)$ & $(1.25)$ \\
\hline \multirow[t]{2}{*}{ Relative size (sales) } & -0.00773 & $-0.0406^{*}$ & -0.00356 & -0.0237 & & & & & & & & \\
\hline & $(-1.38)$ & $(-2.18)$ & $(-0.59)$ & $(-1.62)$ & & & & & & & & \\
\hline \multirow[t]{2}{*}{ Relative size (asset) } & & & & & -0.0785 & $-8.869^{*}$ & 0.317 & $-7.643^{*}$ & & & & \\
\hline & & & & & $(-0.15)$ & $(-2.00)$ & $(0.86)$ & $(-2.14)$ & & & & \\
\hline Relative size (market value) & & & & & & & & & $-0.00109 *$ & $-0.0015^{* * *}$ & -0.00304 & 0.00726 \\
\hline \multirow[t]{2}{*}{ Number of competing bids } & $0.221 * * *$ & $0.297 * * *$ & 0.111 & 0.150 & $0.214^{* * * *}$ & $0.294 * * *$ & $0.129^{*}$ & 0.149 & $0.163 * * *$ & $0.257 * * *$ & 0.0255 & 0.0737 \\
\hline & $(6.31)$ & $(5.11)$ & $(1.80)$ & $(1.57)$ & $(6.18)$ & $(5.16)$ & $(2.30)$ & $(1.61)$ & $(5.32)$ & $(4.73)$ & $(1.22)$ & $(1.00)$ \\
\hline \multirow[t]{2}{*}{ Cash } & 0.0000581 & 0 & 0 & 0 & 0.00246 & 0 & 0 & 0 & $0.0686^{* * *}$ & 0 & 0 & 0 \\
\hline & $(0.00)$ & (.) & (.) & (.) & $(0.11)$ & (.) & (.) & (.) & $(3.45)$ & (.) & (.) & (.) \\
\hline \multirow[t]{2}{*}{ Stock } & 0.0165 & 0 & 0 & 0 & 0.0309 & 0 & 0 & 0 & $0.0835^{* * *}$ & 0 & 0 & 0 \\
\hline & $(0.87)$ & (.) & (.) & (.) & $(1.67)$ & (.) & (.) & (.) & (4.99) & (.) & (.) & (.) \\
\hline Tender offer & (7.34) & (5.56) & $(1.89)$ & $(2.20)$ & $(6.56)$ & (5.08) & $(1.84)$ & $(2.30)$ & (4.52) & (4.09) & $(-0.70)$ & $(2.67)$ \\
\hline \multirow[t]{2}{*}{ Merger of equal } & $-0.281 * * *$ & 0 & $-0.298 * * *$ & -0.0879 & $-0.284 * * *$ & 0 & $-0.317 * * *$ & -0.0649 & $-0.222 * * *$ & 0 & $-0.0476^{*}$ & -0.0326 \\
\hline & $(-5.68)$ & (.) & $(-5.44)$ & $(-1.71)$ & $(-5.72)$ & (.) & $(-5.79)$ & $(-1.48)$ & $(-5.72)$ & (.) & $(-1.98)$ & $(-0.77)$ \\
\hline \multirow[t]{2}{*}{ Deal size } & $0.0529^{*}$ & -0.0185 & $0.119^{* *}$ & -0.118 & $0.0856^{* * *}$ & 0.0442 & $0.158^{* * * *}$ & 0.0783 & $0.715^{* * *}$ & $0.306^{* * *}$ & $2.545 * * *$ & 1.332 \\
\hline & $(2.33)$ & $(-0.70)$ & $(2.97)$ & $(-1.83)$ & $(4.51)$ & $(1.52)$ & $(4.32)$ & $(1.01)$ & $(7.19)$ & (5.03) & (13.89) & (1.95) \\
\hline \multirow[t]{2}{*}{ Hostile acquisition } & -0.00974 & -0.0292 & -0.152 & 0.136 & -0.0266 & -0.0576 & -0.204 & $0.209^{*}$ & -0.0227 & -0.0540 & -0.00851 & 0.0564 \\
\hline & $(-0.18)$ & $(-0.35)$ & $(-1.36)$ & $(1.33)$ & $(-0.48)$ & $(-0.69)$ & $(-1.75)$ & $(2.04)$ & $(-0.53)$ & $(-0.74)$ & $(-0.13)$ & $(0.72)$ \\
\hline \multirow[t]{2}{*}{ Number of day to effective } & 0.00000488 & -0.0000209 & 0.0000999 & 0.000557 & 0.00000864 & -0.0000201 & $0.000251^{*}$ & 0.000681 & 0.0000643 & 0.00000712 & $0.000202 *$ & 0.000282 \\
\hline & $(0.17)$ & $(-0.82)$ & $(0.83)$ & $(1.52)$ & $(0.30)$ & $(-0.79)$ & (2.04) & $(1.81)$ & (1.68) & $(0.26)$ & (2.05) & $(1.20)$ \\
\hline \multirow[t]{2}{*}{ Target resistance to takeover } & 0.0626 & 0.104 & 0.0575 & $-0.420^{* *}$ & 0.0733 & 0.124 & 0.0251 & $-0.508 * *$ & 0.0662 & 0.124 & -0.0410 & $-0.344 * *$ \\
\hline & $(0.89)$ & $(1.51)$ & $(0.55)$ & $(-2.64)$ & $(1.06)$ & $(1.77)$ & $(0.24)$ & $(-3.31)$ & $(1.20)$ & $(1.83)$ & $(-0.59)$ & $(-2.82)$ \\
\hline \multirow[t]{2}{*}{ Target business risk } & -2.036 & -2.052 & 1.466 & 10.51 & -0.340 & -1.540 & $5.884^{*}$ & 8.373 & -0.204 & -2.191 & $2.926 *$ & 0.933 \\
\hline & $(-0.45)$ & $(-0.83)$ & $(0.51)$ & (1.34) & $(-0.07)$ & $(-0.63)$ & (2.05) & $(1.23)$ & $(-0.05)$ & $(-0.94)$ & (2.14) & $(0.18)$ \\
\hline Target firm size (sales) & $-0.0766^{* *}$ & 0.00378 & $-0.148^{* * *}$ & 0.0670 & & & & & & & & \\
\hline Target firm size (assets) & & & & & $(-5.94)$ & $(-2.99)$ & $(-5.83)$ & $(-2.02)$ & & & & \\
\hline \multirow[t]{2}{*}{ Target firm size (market value) } & & & & & & & & & $-0.732 * * *$ & $-0.335 * * *$ & $-2.553 * * *$ & $-1.354^{*}$ \\
\hline & & & & & & & & & $(-7.35)$ & $(-5.46)$ & $(-13.90)$ & $(-2.00)$ \\
\hline
\end{tabular}




\begin{tabular}{|c|c|c|c|c|c|c|c|c|c|c|c|c|}
\hline \multirow[t]{2}{*}{ Target market to book ratio } & $-0.000253 * *$ & $-0.00226^{*}$ & $-0.000720^{*}$ & 0.000248 & $-0.000277 * *$ & $-0.00333 * *$ & $-0.000626^{*}$ & 0.000379 & $-0.000189 *$ & $-0.00174 *$ & $0.00036^{* * *}$ & 0.000152 \\
\hline & $(-2.73)$ & $(-2.33)$ & $(-2.40)$ & (1.16) & $(-2.99)$ & $(-2.61)$ & $(-2.04)$ & $(1.49)$ & $(-2.10)$ & $(-2.27)$ & $(-3.45)$ & $(1.18)$ \\
\hline Target ROA & $0.000857^{*}$ & 0.0000772 & 0.00183 & 0.00202 & $0.00107 *$ & -0.0000704 & $0.00362 * *$ & 0.000520 & 0.000470 & 0.000191 & -0.000505 & -0.000112 \\
\hline \multirow[t]{2}{*}{ Target ROE } & 0.00000757 & -0.0000150 & 0.000176 & 0.0000202 & 0.00000366 & $-0.0000225^{*}$ & -0.0000166 & 0.000304 & $\begin{array}{c}- \\
0.00000022 \\
6\end{array}$ & -0.0000133 & -0.0000625 & 0.000223 \\
\hline & $(0.26)$ & $(-0.79)$ & $(0.98)$ & $(0.04)$ & $(0.12)$ & $(-2.40)$ & $(-0.08)$ & $(0.54)$ & $(-0.01)$ & $(-0.70)$ & $(-0.88)$ & $(0.60)$ \\
\hline \multirow[t]{2}{*}{ Target operating cashflow } & -0.000772 & -0.00883 & 0.000165 & -0.00308 & -0.000525 & -0.00723 & $0.00078^{* * *}$ & -0.00674 & -0.000547 & -0.00800 & $0.00029 * * *$ & -0.00419 \\
\hline & $(-0.52)$ & $(-1.91)$ & $(0.86)$ & $(-0.73)$ & $(-0.33)$ & $(-1.56)$ & $(7.92)$ & $(-1.74)$ & $(-0.38)$ & $(-1.92)$ & $(4.56)$ & $(-1.52)$ \\
\hline \multirow[t]{2}{*}{ Target financial independence } & 0.0110 & -0.0434 & -0.0689 & -0.0761 & 0.0230 & -0.0191 & -0.0556 & 0.000969 & -0.0129 & -0.0299 & -0.0347 & -0.00453 \\
\hline & $(0.21)$ & $(-0.80)$ & $(-0.90)$ & $(-0.55)$ & $(0.46)$ & $(-0.37)$ & $(-0.73)$ & $(-0.01)$ & $(-0.29)$ & $(-0.58)$ & $(-1.11)$ & $(-0.05)$ \\
\hline \multirow[t]{2}{*}{ Target debt to equity } & -0.0000253 & $0.00297^{*}$ & -0.00144 & ${ }_{0.00716^{* *}}^{-}$ & 0.000354 & $0.00542 * * *$ & 0.00111 & -0.00319 & 0.0000956 & $0.00297 *$ & 0.000333 & -0.00185 \\
\hline & $(-0.09)$ & $(2.04)$ & $(-0.99)$ & $(-2.90)$ & $(1.08)$ & $(3.62)$ & $(0.75)$ & $(-1.26)$ & $(0.35)$ & $(2.07)$ & $(0.58)$ & $(-0.85)$ \\
\hline Public bidder & (1.68) & $(0.65)$ & (1.76) & $(2.15)$ & $(2.18)$ & $(0.59)$ & (1.73) & (3.09) & $(1.96)$ & $(0.79)$ & $(0.38)$ & $(3.59)$ \\
\hline \multirow[t]{2}{*}{$\begin{array}{l}\text { Target shares owned by bidder } \\
\text { before M\&A }\end{array}$} & -0.0553 & -0.0767 & -0.0497 & $-0.319^{*}$ & -0.00150 & 0.000170 & -0.00000741 & -0.211 & $0.522 * * *$ & $0.201 *$ & $2.186^{* * *}$ & 1.022 \\
\hline & $(-0.83)$ & $(-0.80)$ & $(-0.44)$ & $(-2.47)$ & $(-0.02)$ & $(0.00)$ & $(-0.00)$ & $(-1.60)$ & $(5.10)$ & (2.00) & $(9.38)$ & (1.56) \\
\hline \multirow[t]{2}{*}{$\begin{array}{l}\text { Target shares owned by bidder } \\
\text { after M\&A }\end{array}$} & $0.249 * * *$ & $0.336 * * *$ & -0.164 & -0.143 & $0.218 * * *$ & $0.254 * * *$ & -0.122 & -0.166 & $-0.595 * * *$ & -0.0700 & $-2.981 * * *$ & -0.166 \\
\hline & $(6.28)$ & (8.61) & $(-0.91)$ & $(-0.80)$ & $(6.89)$ & $(5.97)$ & $(-0.71)$ & $(-0.97)$ & $(-4.23)$ & $(-0.83)$ & $(-9.85)$ & $(-1.25)$ \\
\hline \multirow[t]{2}{*}{ _cons } & -0.138 & -0.253 & 0.183 & 0.100 & -0.139 & -0.0874 & 0.0737 & 0.0881 & $0.590 * * *$ & 0.168 & $2.855 * * *$ & -0.259 \\
\hline & $(-1.11)$ & $(-1.52)$ & $(0.93)$ & $(0.41)$ & $(-1.24)$ & $(-0.51)$ & $(0.39)$ & $(0.35)$ & $(3.52)$ & (1.02) & $(9.72)$ & $(-1.15)$ \\
\hline $\mathbf{N}$ & 2559 & 1029 & 741 & 275 & 2559 & 1029 & 741 & 275 & 2559 & 1029 & 741 & 275 \\
\hline adj.R-sq & 0.264 & 0.507 & 0.116 & 0.332 & 0.272 & 0.513 & 0.141 & 0.351 & 0.386 & 0.539 & 0.763 & 0.568 \\
\hline
\end{tabular}




\subsubsection{Regressions with interaction terms between volatility and real option variables}

We test $\mathrm{H} 2$ by adding seven interaction terms between the target volatility and seven target real option variables to the main regressions. Also, we add three interaction terms between the bidder volatility and three bidder real option variables to the main regressions. We run the regressions for all three measures of firm size as well as full sample, stock sample, cash sample, and mix sample. Two different measures of volatility are also tested. The results are illustrated in table 10 for idiosyncratic volatility and table 11 for total volatility.

\section{- Regressions using idiosyncratic volatility}

The regression (1), (2), (5), (6), (9), and (10) of table 10 show a positive and significant effect of the interaction between target idiosyncratic volatility and target R\&D to market value on M\&A premiums in the full sample and pure cash deals sample. These results are consistent with all three measures of firm size. Thus, the positive relationship between target idiosyncratic volatility and M\&A premiums is stronger when target firms have high $R \& D$ to the market ratio in full sample and pure cash sample.

As can be seen in the regression (3), (7) and (11) of table 10, the estimated coefficients of the interaction term between target idiosyncratic volatility and target financial flexibility (leverage) are negative at $1 \%$ level of significance when firm size is measured as sales or assets, and at $5 \%$ level of significant when firm size is measured as market value. This result indicates that the acquisition premiums are higher, when target firms have high idiosyncratic volatility and low leverage ratio.

In the regression (1) and (9) of table 10, interaction terms between target idiosyncratic volatility and target sales growth rate have a positive estimated coefficient that is significant at $5 \%$ 
in regression (1) and $1 \%$ in regression (9) respectively. So, the positive relationship between target idiosyncratic volatility and M\&A premium is significantly higher when target firms have higher sales growth rate. This result is only significant when we measure firm size as the total sales or market value.

The regression (4) of table 10 shows a negative coefficient of the interaction term between bidder idiosyncratic volatility and bidder R\&D to market value that is significant at 5\% level. This result indicates that the positive relationship between bidder return volatility is stronger when bidder firms have low $\mathrm{R} \& \mathrm{D}$ to market value ratio.

\section{- Regressions using total volatility}

Table 11 depicts the results when we replace idiosyncratic volatility with total volatility. As can be seen in the regression (1) of table 11, the estimated coefficient for the interaction term between target total volatility and target R\&D to market value is no longer significant. In the regression (3), (7), and (11) of table 11, the coefficient of the interaction term between target total volatility and target financial leverage ratio is only negative and significant at $5 \%$ level when we measure firm size as market value. When we use idiosyncratic volatility, the interaction term between target idiosyncratic volatility and target financial leverage ratio is significant in all three measurements of firm size. As shown in the regression (4) of table 11, and regression (4) of table 11 , the interaction term between bidder volatility and bidder $R \& D$ to market value is only significant when firm size is measured as sales and when we use idiosyncratic volatility in the model. Thus, the idiosyncratic volatility seems like a better measure of stock return volatility than the total volatility. 
Table 10: Regression results of S\&P adjusted M\&A premiums, idiosyncratic volatility, real option variables, and interaction terms between idiosyncratic volatility and real option variables

\begin{tabular}{|c|c|c|c|c|c|c|c|c|c|c|c|c|}
\hline & \multicolumn{4}{|c|}{ Sales } & \multicolumn{4}{|c|}{ Assets } & \multicolumn{4}{|c|}{ Market value } \\
\hline & (1) & (2) & (3) & (4) & (5) & (6) & (7) & (8) & (9) & (10) & (11) & (12) \\
\hline $\begin{array}{l}\text { Dependent variable: M\&A } \\
\text { premiums (S\&P adjusted) }\end{array}$ & Full & Cash & Stock & Mix & Full & Cash & Stock & Mix & Full & Cash & Stock & Mix \\
\hline \multirow{2}{*}{ Target idiosyncratic volatility } & 9.022 & 3.523 & $33.49 * * *$ & 2.992 & 6.354 & 1.810 & $29.98^{* *}$ & -7.827 & 1.749 & -0.540 & $10.88^{*}$ & -7.043 \\
\hline & $(1.66)$ & $(0.54)$ & (3.31) & $(0.12)$ & $(1.15)$ & $(0.28)$ & $(2.98)$ & $(-0.30)$ & $(0.35)$ & $(-0.09)$ & $(2.25)$ & $(-0.36)$ \\
\hline \multirow[t]{2}{*}{ Bidder idiosyncratic volatility } & -0.373 & $-2.511^{* * *}$ & -0.0326 & 3.430 & -0.606 & $-2.281 * *$ & -0.631 & 2.686 & -0.243 & $-2.264 * * *$ & -0.190 & $2.473 *$ \\
\hline & $(-0.77)$ & $(-3.45)$ & $(-0.05)$ & $(1.88)$ & $(-1.34)$ & $(-3.16)$ & $(-1.01)$ & $(1.58)$ & $(-0.62)$ & $(-3.42)$ & $(-0.63)$ & $(2.04)$ \\
\hline \multirow[t]{2}{*}{ Target $R \& D$ to market value } & 0.149 & -0.388 & 1.695 & -0.367 & -0.0315 & -0.277 & 1.095 & -0.594 & -0.0132 & -0.408 & 0.197 & -0.845 \\
\hline & $(0.36)$ & $(-0.76)$ & $(1.95)$ & $(-0.21)$ & $(-0.08)$ & $(-0.52)$ & $(1.36)$ & $(-0.35)$ & $(-0.03)$ & $(-0.79)$ & $(0.44)$ & $(-0.75)$ \\
\hline \multirow[t]{2}{*}{ Target $R \& D$ to sales } & 0.0466 & 0.0208 & -0.0592 & 0.337 & 0.0493 & 0.0138 & -0.0162 & 0.294 & 0.0471 & 0.0194 & -0.00176 & 0.245 \\
\hline & $(1.43)$ & $(1.18)$ & $(-1.31)$ & $(1.75)$ & $(1.35)$ & $(0.80)$ & $(-0.37)$ & $(1.70)$ & $(1.31)$ & $(1.18)$ & $(-0.08)$ & $(1.96)$ \\
\hline \multirow[t]{2}{*}{ Target R\&D growth } & -0.0200 & -0.0387 & -0.0613 & 0.246 & -0.0241 & -0.0312 & -0.0530 & 0.346 & -0.00443 & -0.0188 & -0.0302 & 0.258 \\
\hline & $(-0.95)$ & $(-0.89)$ & $(-0.95)$ & $(0.81)$ & $(-1.13)$ & $(-0.74)$ & $(-0.75)$ & $(1.16)$ & $(-0.24)$ & $(-0.45)$ & $(-1.05)$ & $(1.25)$ \\
\hline \multirow[t]{2}{*}{ Target organizational flexibility } & 0.00116 & $0.195^{*}$ & 0.0534 & 0.0677 & 0.00433 & 0.137 & 0.0234 & -0.0785 & -0.00293 & $0.178^{*}$ & 0.00736 & 0.0416 \\
\hline & $(0.13)$ & $(2.42)$ & $(0.88)$ & $(0.18)$ & $(0.52)$ & (1.63) & $(0.38)$ & $(-0.20)$ & $(-0.34)$ & $(2.27)$ & $(0.24)$ & $(0.18)$ \\
\hline \multirow[t]{2}{*}{$\begin{array}{l}\text { Target financial flexibility } \\
\text { (leverage) }\end{array}$} & 0.0602 & 0.129 & $0.321 *$ & 0.440 & 0.193 & $0.179^{*}$ & $0.601 * * *$ & 0.438 & 0.0540 & 0.128 & $0.136^{*}$ & 0.216 \\
\hline & $(0.45)$ & $(1.91)$ & $(2.44)$ & (1.79) & (1.38) & $(2.47)$ & $(4.47)$ & $(1.81)$ & $(0.43)$ & $(1.91)$ & $(2.10)$ & (1.09) \\
\hline \multirow[t]{2}{*}{$\begin{array}{l}\text { Target financial flexibility } \\
\text { (cashflow coverage) }\end{array}$} & -0.0343 & -0.0115 & -0.0159 & 0.0121 & -0.0564 & -0.0120 & -0.0674 & -0.0425 & -0.0107 & -0.000268 & 0.0271 & 0.0840 \\
\hline & $(-0.93)$ & $(-0.26)$ & $(-0.21)$ & $(0.07)$ & $(-1.53)$ & $(-0.28)$ & $(-1.04)$ & $(-0.27)$ & $(-0.32)$ & $(-0.01)$ & $(1.12)$ & $(0.73)$ \\
\hline \multirow[t]{2}{*}{ Target sales growth } & $-0.00115^{* *}$ & 0.00948 & 0.00899 & -0.110 & -0.000734 & 0.00426 & 0.00179 & -0.133 & $-0.00156^{* * * *}$ & -0.00118 & 0.00345 & -0.0553 \\
\hline & $(-2.80)$ & $(0.29)$ & $(0.27)$ & $(-1.09)$ & $(-1.56)$ & $(0.13)$ & $(0.05)$ & $(-1.36)$ & $(-3.35)$ & $(-0.04)$ & $(0.25)$ & $(-0.86)$ \\
\hline \multirow[t]{2}{*}{ Bidder R\&D to market value } & -0.00924 & -0.0109 & -0.0313 & $0.0595^{*}$ & -0.00327 & -0.0122 & -0.0278 & 0.0448 & 0.000540 & -0.00664 & -0.00496 & 0.0390 \\
\hline & $(-0.65)$ & $(-0.18)$ & $(-1.18)$ & $(2.18)$ & $(-0.23)$ & $(-0.22)$ & $(-1.00)$ & $(1.49)$ & $(0.04)$ & $(-0.12)$ & $(-0.52)$ & $(1.67)$ \\
\hline \multirow[t]{2}{*}{ Bidder R\&D to sales } & -0.00910 & -0.000105 & 0.138 & -1.194 & 0.0165 & 0.0149 & 0.131 & -1.362 & -0.00420 & 0.00520 & 0.0452 & -0.791 \\
\hline & $(-0.17)$ & $(-0.00)$ & $(0.74)$ & $(-1.23)$ & $(0.31)$ & $(0.16)$ & $(0.68)$ & $(-1.39)$ & $(-0.08)$ & $(0.05)$ & $(0.52)$ & $(-0.98)$ \\
\hline \multirow[t]{2}{*}{ Bidder R\&D growth } & 0.0162 & -0.0148 & -0.0239 & 0.110 & 0.0230 & -0.0207 & -0.0235 & 0.0800 & 0.0183 & -0.0130 & -0.0149 & 0.121 \\
\hline & $(0.61)$ & $(-0.33)$ & $(-0.37)$ & $(0.85)$ & $(0.88)$ & $(-0.44)$ & $(-0.37)$ & $(0.65)$ & $(0.74)$ & $(-0.28)$ & $(-0.62)$ & (1.13) \\
\hline
\end{tabular}




\begin{tabular}{|c|c|c|c|c|c|c|c|c|c|c|c|c|}
\hline \multirow{2}{*}{$\begin{array}{l}\text { Target idiosyncratic volatility * } \\
\text { Target R\&D to market value }\end{array}$} & $21.26^{*}$ & $34.04 * *$ & 0.974 & 32.41 & $24.69^{*}$ & $32.55^{*}$ & 10.42 & 38.97 & $22.01 *$ & $33.60^{* *}$ & 2.375 & 28.03 \\
\hline & $(2.05)$ & $(2.76)$ & $(0.06)$ & $(0.69)$ & $(2.41)$ & $(2.55)$ & $(0.65)$ & $(0.88)$ & $(2.32)$ & (2.76) & $(0.24)$ & $(0.99)$ \\
\hline \multirow[t]{2}{*}{$\begin{array}{l}\text { Target idiosyncratic volatility * } \\
\text { Target R\&D to sales }\end{array}$} & -0.851 & -0.379 & 0.669 & -11.26 & -0.896 & -0.255 & 0.0674 & -12.22 & -0.859 & -0.361 & -0.0864 & -9.157 \\
\hline & $(-1.42)$ & $(-1.14)$ & $(0.95)$ & $(-1.51)$ & $(-1.33)$ & $(-0.78)$ & $(0.10)$ & $(-1.75)$ & $(-1.30)$ & $(-1.16)$ & $(-0.26)$ & $(-1.90)$ \\
\hline \multirow[t]{2}{*}{$\begin{array}{l}\text { Target idiosyncratic volatility * } \\
\text { Target R\&D growth }\end{array}$} & 0.269 & 0.703 & 0.851 & -5.082 & 0.399 & 0.419 & 0.949 & -7.201 & 0.0331 & 0.214 & 0.462 & -5.255 \\
\hline & $(0.70)$ & $(0.57)$ & $(0.66)$ & $(-0.60)$ & $(1.01)$ & $(0.35)$ & $(0.68)$ & $(-0.89)$ & $(0.10)$ & $(0.17)$ & $(0.73)$ & $(-1.03)$ \\
\hline \multirow[t]{2}{*}{$\begin{array}{l}\text { Target idiosyncratic volatility* } \\
\text { Target organizational flexibility }\end{array}$} & -0.248 & -3.939 & -1.336 & -1.082 & -0.412 & -3.205 & -0.620 & 2.297 & -0.0953 & -3.746 & -0.249 & 0.274 \\
\hline & $(-0.41)$ & $(-1.72)$ & $(-1.20)$ & $(-0.11)$ & $(-0.69)$ & $(-1.40)$ & $(-0.56)$ & $(0.22)$ & $(-0.17)$ & $(-1.74)$ & $(-0.42)$ & $(0.04)$ \\
\hline \multirow[t]{2}{*}{$\begin{array}{l}\text { Target idiosyncratic volatility * } \\
\text { Target financial flexibility } \\
\text { (leverage) }\end{array}$} & -3.592 & 4.388 & $-31.45^{* *}$ & -9.122 & -2.362 & 5.190 & $-31.11 * *$ & 2.143 & 0.883 & 7.370 & $-12.15^{*}$ & 6.346 \\
\hline & $(-0.51)$ & $(0.66)$ & $(-3.00)$ & $(-0.32)$ & $(-0.33)$ & $(0.79)$ & $(-3.01)$ & $(0.07)$ & $(0.14)$ & (1.18) & $(-2.47)$ & $(0.30)$ \\
\hline \multirow[t]{2}{*}{$\begin{array}{l}\text { Target idiosyncratic volatility * } \\
\text { Target financial flexibility } \\
\text { (cashflow coverage) }\end{array}$} & 0.0622 & 0.341 & 0.271 & -1.733 & 0.103 & 0.235 & 0.653 & -1.207 & -0.570 & -0.229 & -0.574 & -3.581 \\
\hline & $(0.07)$ & $(0.19)$ & $(0.19)$ & $(-0.29)$ & $(0.11)$ & $(0.13)$ & $(0.54)$ & $(-0.22)$ & $(-0.66)$ & $(-0.13)$ & $(-1.16)$ & $(-0.96)$ \\
\hline \multirow[t]{2}{*}{$\begin{array}{l}\text { Target idiosyncratic volatility * } \\
\text { Target sales growth }\end{array}$} & $0.0160 *$ & -0.557 & -0.136 & 2.518 & 0.00926 & -0.389 & -0.0287 & 3.001 & $0.0223 * *$ & -0.147 & -0.0524 & 1.295 \\
\hline & $(2.49)$ & $(-0.45)$ & $(-0.27)$ & $(1.22)$ & (1.27) & $(-0.31)$ & $(-0.05)$ & $(1.50)$ & (3.10) & $(-0.13)$ & $(-0.25)$ & $(1.02)$ \\
\hline \multirow[t]{2}{*}{$\begin{array}{l}\text { Bidder idiosyncratic volatility * } \\
\text { Bidder } R \& D \text { to market value }\end{array}$} & 0.571 & 0.814 & 1.336 & $-2.897 *$ & 0.358 & 1.036 & 1.171 & -2.211 & 0.172 & 0.605 & 0.280 & -1.588 \\
\hline & $(1.21)$ & $(0.40)$ & $(1.74)$ & $(-2.02)$ & $(0.74)$ & $(0.54)$ & $(1.45)$ & $(-1.38)$ & $(0.40)$ & $(0.33)$ & $(1.07)$ & $(-1.30)$ \\
\hline \multirow[t]{2}{*}{$\begin{array}{l}\text { Bidder idiosyncratic volatility * } \\
\text { Bidder R\&D to sales }\end{array}$} & -0.0941 & -3.491 & -1.937 & 78.49 & -0.753 & -3.594 & -2.009 & 89.29 & 0.169 & -3.143 & -0.799 & 51.39 \\
\hline & $(-0.05)$ & $(-1.35)$ & $(-0.49)$ & $(1.28)$ & $(-0.45)$ & $(-1.40)$ & $(-0.51)$ & $(1.45)$ & $(0.11)$ & $(-1.22)$ & $(-0.52)$ & $(1.01)$ \\
\hline \multirow[t]{2}{*}{$\begin{array}{l}\text { Bidder idiosyncratic volatility * } \\
\text { Bidder R\&D growth }\end{array}$} & -0.288 & 0.726 & 0.506 & -12.06 & -0.434 & 0.869 & 0.500 & -11.27 & -0.336 & 0.607 & 0.302 & -10.29 \\
\hline & $(-0.51)$ & $(0.63)$ & $(0.37)$ & $(-1.32)$ & $(-0.78)$ & $(0.76)$ & $(0.37)$ & $(-1.29)$ & $(-0.64)$ & $(0.57)$ & $(0.60)$ & $(-1.39)$ \\
\hline \multirow[t]{2}{*}{ _cons } & -0.158 & -0.300 & 0.0292 & 0.0604 & -0.139 & -0.128 & 0.00966 & 0.110 & $0.585^{* * *}$ & 0.140 & $2.814 * * *$ & -0.331 \\
\hline & $(-1.31)$ & $(-1.88)$ & $(0.14)$ & $(0.22)$ & $(-1.26)$ & $(-0.76)$ & $(0.04)$ & $(0.41)$ & $(3.50)$ & $(0.88)$ & $(9.12)$ & $(-1.39)$ \\
\hline $\mathbf{N}$ & 2559 & 1029 & 741 & 275 & 2559 & 1029 & 741 & 275 & 2559 & 1029 & 741 & 275 \\
\hline adj.R-sq & 0.268 & 0.513 & 0.122 & 0.339 & 0.276 & 0.518 & 0.142 & 0.371 & 0.389 & 0.545 & 0.761 & 0.57 \\
\hline
\end{tabular}


Table 11: Regression results of S\&P adjusted M\&A premiums, total volatility, real option variables, and interaction terms between total volatility and real option variable

\begin{tabular}{|c|c|c|c|c|c|c|c|c|c|c|c|c|}
\hline & \multicolumn{4}{|c|}{ Sales } & \multicolumn{4}{|c|}{ Assets } & \multicolumn{4}{|c|}{ Market value } \\
\hline & (1) & (2) & (3) & (4) & (5) & (6) & (7) & (8) & (9) & (10) & (11) & (12) \\
\hline $\begin{array}{l}\text { Dependent variable: M\&A } \\
\text { premiums (S\&P adjusted) }\end{array}$ & Full & Cash & Stock & Mix & Full & Cash & Stock & Mix & Full & Cash & Stock & Mix \\
\hline \multirow[t]{2}{*}{ Target total volatility } & $5.339 *$ & $7.958 * * *$ & $4.921 *$ & -7.117 & 3.943 & $7.180 * * *$ & $5.771 *$ & -6.064 & 2.665 & $6.926 * * *$ & $2.220^{*}$ & -0.833 \\
\hline & $(2.01)$ & $(3.83)$ & (1.97) & $(-1.23)$ & (1.47) & $(3.43)$ & $(2.41)$ & $(-1.25)$ & (1.14) & (3.64) & $(1.96)$ & $(-0.24)$ \\
\hline \multirow[t]{2}{*}{ Bidder total volatility } & -0.373 & $-2.111 * *$ & -0.313 & $3.379 *$ & -0.545 & $-1.904 * *$ & -0.767 & 3.066 & -0.179 & $-1.887 * *$ & -0.282 & $2.567 *$ \\
\hline & $(-0.82)$ & $(-3.01)$ & $(-0.50)$ & (1.98) & $(-1.25)$ & $(-2.71)$ & $(-1.24)$ & $(1.84)$ & $(-0.48)$ & $(-2.98)$ & $(-1.09)$ & $(2.07)$ \\
\hline \multirow[t]{2}{*}{ Target R\&D to market value } & 0.103 & -0.625 & $2.017 *$ & -0.657 & -0.101 & -0.510 & 1.413 & -0.799 & -0.0484 & -0.623 & 0.205 & -1.149 \\
\hline & $(0.22)$ & $(-1.07)$ & $(2.44)$ & $(-0.35)$ & $(-0.22)$ & $(-0.85)$ & $(1.81)$ & $(-0.46)$ & $(-0.11)$ & $(-1.06)$ & $(0.51)$ & $(-0.96)$ \\
\hline \multirow[t]{2}{*}{ Target $R \& D$ to sales } & 0.0392 & 0.0167 & -0.0883 & $0.475^{*}$ & 0.0400 & 0.0106 & -0.0273 & $0.454^{*}$ & 0.0415 & 0.0166 & -0.00371 & $0.355^{*}$ \\
\hline & $(1.21)$ & $(0.98)$ & $(-1.52)$ & $(2.00)$ & $(1.12)$ & $(0.63)$ & $(-0.48)$ & $(2.10)$ & $(1.19)$ & $(1.05)$ & $(-0.14)$ & $(2.26)$ \\
\hline \multirow[t]{2}{*}{ Target $R \& D$ growth } & -0.0193 & -0.0192 & -0.0566 & 0.307 & -0.0252 & -0.0134 & -0.0503 & 0.415 & -0.00440 & -0.00083 & -0.0225 & 0.248 \\
\hline & $(-0.89)$ & $(-0.43)$ & $(-0.93)$ & $(0.88)$ & $(-1.15)$ & $(-0.31)$ & $(-0.76)$ & $(1.21)$ & $(-0.23)$ & $(-0.02)$ & $(-0.78)$ & (1.04) \\
\hline \multirow[t]{2}{*}{ Target organizational flexibility } & 0.00135 & $0.194 *$ & 0.0779 & 0.212 & 0.00457 & 0.133 & 0.0384 & 0.0153 & -0.00264 & $0.179 *$ & 0.0138 & 0.162 \\
\hline & $(0.15)$ & $(2.29)$ & $(1.30)$ & $(0.49)$ & $(0.55)$ & $(1.50)$ & $(0.63)$ & $(0.04)$ & $(-0.31)$ & $(2.19)$ & $(0.48)$ & $(0.56)$ \\
\hline \multirow{2}{*}{$\begin{array}{l}\text { Target financial flexibility } \\
\text { (leverage) }\end{array}$} & 0.0419 & 0.0995 & $0.266^{*}$ & 0.494 & 0.177 & 0.146 & $0.553 * * *$ & 0.445 & 0.0370 & 0.0938 & 0.112 & 0.205 \\
\hline & $(0.30)$ & $(1.43)$ & $(1.99)$ & $(1.82)$ & $(1.22)$ & $(1.94)$ & $(4.00)$ & $(1.71)$ & $(0.28)$ & $(1.39)$ & $(1.82)$ & $(0.96)$ \\
\hline \multirow{2}{*}{$\begin{array}{l}\text { Target financial flexibility } \\
\text { (cashflow coverage) }\end{array}$} & -0.0438 & -0.00611 & -0.0325 & -0.0612 & $-0.0707 *$ & -0.00678 & -0.0850 & -0.128 & -0.0165 & 0.00799 & 0.0201 & 0.0305 \\
\hline & $(-1.22)$ & $(-0.14)$ & $(-0.45)$ & $(-0.34)$ & $(-1.99)$ & $(-0.16)$ & $(-1.36)$ & $(-0.78)$ & $(-0.52)$ & $(0.19)$ & $(0.89)$ & $(0.26)$ \\
\hline \multirow[t]{2}{*}{ Target sales growth } & $-0.00109 * *$ & 0.0212 & 0.00692 & -0.134 & -0.000667 & 0.0180 & 0.000114 & -0.158 & $-0.0015^{* * *}$ & 0.00323 & 0.00291 & -0.0669 \\
\hline & $(-2.76)$ & $(0.37)$ & $(0.20)$ & $(-1.20)$ & $(-1.47)$ & $(0.31)$ & $(0.00)$ & $(-1.48)$ & $(-3.35)$ & $(0.06)$ & $(0.20)$ & $(-0.91)$ \\
\hline \multirow[t]{2}{*}{ Bidder R\&D to market value } & 0.000780 & -0.0257 & -0.00384 & 0.0396 & 0.00369 & -0.0237 & -0.0122 & 0.0286 & 0.00550 & -0.0139 & -0.00289 & 0.0245 \\
\hline & $(0.05)$ & $(-0.34)$ & $(-0.15)$ & $(1.29)$ & $(0.25)$ & $(-0.33)$ & $(-0.50)$ & $(0.91)$ & $(0.42)$ & $(-0.20)$ & $(-0.33)$ & $(1.16)$ \\
\hline \multirow[t]{2}{*}{ Bidder R\&D to sales } & 0.00572 & 0.0136 & 0.191 & -0.820 & 0.0320 & 0.0273 & 0.191 & -1.018 & 0.00829 & 0.0137 & 0.0598 & -0.435 \\
\hline & $(0.10)$ & $(0.14)$ & $(1.01)$ & $(-0.89)$ & $(0.59)$ & $(0.30)$ & $(0.99)$ & $(-1.10)$ & $(0.16)$ & $(0.13)$ & $(0.70)$ & $(-0.59)$ \\
\hline \multirow[t]{2}{*}{ Bidder R\&D growth } & 0.0247 & 0.0151 & -0.0179 & -0.0387 & 0.0322 & 0.0101 & -0.0156 & -0.0308 & 0.0254 & 0.0163 & -0.00743 & -0.00042 \\
\hline & $(0.89)$ & $(0.31)$ & $(-0.24)$ & $(-0.28)$ & (1.18) & $(0.20)$ & $(-0.21)$ & $(-0.25)$ & $(0.98)$ & $(0.33)$ & $(-0.27)$ & $(-0.00)$ \\
\hline
\end{tabular}




\begin{tabular}{|c|c|c|c|c|c|c|c|c|c|c|c|c|}
\hline & $(6.47)$ & $(8.81)$ & $(-0.80)$ & $(-0.92)$ & $(6.75)$ & $(6.23)$ & $(-0.76)$ & $(-1.08)$ & $(-4.21)$ & $(-0.75)$ & $(-9.69)$ & $(-1.37)$ \\
\hline \multirow{2}{*}{$\begin{array}{l}\text { Target total volatility * Target } \\
\text { R\&D to market value }\end{array}$} & 20.42 & $36.14 * *$ & -6.768 & 32.87 & $24.20^{*}$ & $34.65^{*}$ & 1.885 & 35.04 & $21.10^{*}$ & $35.50 * *$ & 1.534 & 28.67 \\
\hline & (1.90) & $(2.75)$ & $(-0.50)$ & $(0.72)$ & (2.29) & $(2.57)$ & $(0.14)$ & $(0.83)$ & $(2.16)$ & $(2.76)$ & $(0.20)$ & (1.03) \\
\hline \multirow{2}{*}{$\begin{array}{l}\text { Target total volatility * Target } \\
\text { R\&D to sales }\end{array}$} & -0.695 & -0.295 & 1.144 & -13.06 & -0.705 & -0.189 & 0.285 & -14.32 & -0.735 & -0.302 & -0.0339 & $-10.32^{*}$ \\
\hline & $(-1.20)$ & $(-0.94)$ & $(1.30)$ & $(-1.68)$ & $(-1.10)$ & $(-0.61)$ & $(0.34)$ & $(-1.95)$ & $(-1.17)$ & $(-1.03)$ & $(-0.08)$ & $(-2.03)$ \\
\hline \multirow{2}{*}{$\begin{array}{l}\text { Target total volatility * Target } \\
\text { R\&D growth }\end{array}$} & 0.260 & 0.160 & 0.714 & -6.951 & 0.412 & -0.0562 & 0.839 & -9.288 & 0.0411 & -0.267 & 0.283 & -5.444 \\
\hline & $(0.68)$ & $(0.13)$ & $(0.60)$ & $(-0.78)$ & $(1.05)$ & $(-0.05)$ & $(0.65)$ & $(-1.07)$ & $(0.12)$ & $(-0.21)$ & $(0.46)$ & $(-0.97)$ \\
\hline \multirow{2}{*}{$\begin{array}{l}\text { Target total volatility * Target } \\
\text { organizational flexibility }\end{array}$} & -0.264 & -3.682 & -1.751 & -4.413 & -0.422 & -2.920 & -0.882 & -0.0683 & -0.109 & -3.532 & -0.351 & -2.742 \\
\hline & $(-0.46)$ & $(-1.68)$ & $(-1.72)$ & $(-0.40)$ & $(-0.75)$ & $(-1.33)$ & $(-0.84)$ & $(-0.01)$ & $(-0.20)$ & $(-1.72)$ & $(-0.69)$ & $(-0.38)$ \\
\hline \multirow{2}{*}{$\begin{array}{l}\text { Target total volatility } * \text { Target } \\
\text { financial flexibility (leverage) }\end{array}$} & 0 & 0 & -2.400 & 0 & 0 & 0 & -6.258 & 0 & 0 & 0 & $-3.087^{*}$ & 0 \\
\hline & (.) & (.) & $(-0.71)$ & (.) & (.) & (.) & $(-1.92)$ & (.) & (.) & (.) & $(-2.00)$ & (.) \\
\hline \multirow{2}{*}{$\begin{array}{l}\text { Target total volatility* Target } \\
\text { financial flexibility (cashflow } \\
\text { coverage) }\end{array}$} & 0.184 & 0.120 & 0.479 & 0.650 & 0.295 & 0.0317 & 0.851 & 1.737 & -0.457 & -0.442 & -0.429 & -1.112 \\
\hline & $(0.22)$ & $(0.08)$ & $(0.39)$ & $(0.13)$ & $(0.35)$ & $(0.02)$ & $(0.81)$ & $(0.37)$ & $(-0.59)$ & $(-0.29)$ & $(-1.05)$ & $(-0.37)$ \\
\hline \multirow{2}{*}{$\begin{array}{l}\text { Target total volatility * Target } \\
\text { sales growth }\end{array}$} & $0.0137^{*}$ & -0.797 & -0.0962 & 2.868 & 0.00743 & -0.722 & -0.00338 & 3.308 & $0.0196 * *$ & -0.238 & -0.0406 & 1.447 \\
\hline & $(2.42)$ & $(-0.45)$ & $(-0.21)$ & $(1.33)$ & $(1.15)$ & $(-0.41)$ & $(-0.01)$ & $(1.61)$ & $(3.07)$ & $(-0.14)$ & $(-0.20)$ & (1.05) \\
\hline \multirow{2}{*}{$\begin{array}{l}\text { Bidder total volatility * Bidder } \\
\text { R\&D to market value }\end{array}$} & 0.136 & 1.221 & 0.361 & -1.737 & 0.0550 & 1.324 & 0.551 & -1.198 & -0.0343 & 0.773 & 0.167 & -0.692 \\
\hline & $(0.29)$ & $(0.50)$ & $(0.55)$ & $(-1.34)$ & $(0.12)$ & $(0.57)$ & $(0.89)$ & $(-0.93)$ & $(-0.08)$ & $(0.36)$ & $(0.78)$ & $(-0.71)$ \\
\hline \multirow{2}{*}{$\begin{array}{l}\text { Bidder total volatility * Bidder } \\
\text { R\&D to sales }\end{array}$} & -0.649 & -3.619 & -2.619 & 45.79 & -1.199 & -3.635 & -2.731 & 56.35 & -0.301 & -3.082 & -0.940 & 24.18 \\
\hline & $(-0.45)$ & $(-1.40)$ & $(-0.78)$ & $(0.94)$ & $(-0.88)$ & $(-1.43)$ & $(-0.84)$ & $(1.16)$ & $(-0.23)$ & $(-1.23)$ & $(-0.74)$ & $(0.63)$ \\
\hline \multirow{2}{*}{$\begin{array}{l}\text { Bidder total volatility * Bidder } \\
\text { R\&D growth }\end{array}$} & -0.432 & -0.195 & 0.370 & -1.805 & -0.586 & -0.103 & 0.327 & -3.101 & -0.454 & -0.287 & 0.141 & -1.801 \\
\hline & $(-0.78)$ & $(-0.18)$ & $(0.25)$ & $(-0.21)$ & $(-1.07)$ & $(-0.10)$ & $(0.22)$ & $(-0.41)$ & $(-0.88)$ & $(-0.29)$ & $(0.26)$ & $(-0.25)$ \\
\hline \multirow[t]{2}{*}{ _cons } & -0.118 & -0.275 & 0.124 & 0.00685 & -0.104 & -0.103 & 0.0879 & 0.0800 & $0.605 * * *$ & 0.155 & $2.853 * * *$ & -0.349 \\
\hline & $(-0.94)$ & $(-1.75)$ & $(0.57)$ & $(0.03)$ & $(-0.91)$ & $(-0.62)$ & $(0.40)$ & $(0.30)$ & (3.59) & $(0.97)$ & $(9.30)$ & $(-1.54)$ \\
\hline $\mathbf{N}$ & 2559 & 1029 & 741 & 275 & 2559 & 1029 & 741 & 275 & 2559 & 1029 & 741 & 275 \\
\hline adj.R-sq & 0.266 & 0.515 & 0.11 & 0.336 & 0.276 & 0.521 & 0.133 & 0.367 & 0.389 & 0.547 & 0.76 & 0.565 \\
\hline
\end{tabular}




\subsubsection{Regression with two sub-sample when bidder volatility is higher than target volatility, and when bidder volatility is lower than target volatility}

We create an interaction term between the idiosyncratic volatility of bidder and cash variable because the idiosyncratic volatility of bidder is only significant in cash deals sample. The first sub-sample is when the bidder idiosyncratic volatility is higher target idiosyncratic volatility. The second one is when the bidder idiosyncratic volatility is lower than target idiosyncratic volatility. The table 12 shows that the coefficient of the interaction variable is negative and significant at $1 \%$ level when bidder idiosyncratic volatility is higher than target idiosyncratic volatility. However, the bidder volatility is insignificant when bidder idiosyncratic volatility is lower than target idiosyncratic volatility. This result indicates that when the bidder volatility is higher than target volatility, the bidder firms tend to pay fewer cash premiums when they have more idiosyncratic volatility. 
Table 12: Regressions with two sub-sample when bidder volatility is higher than target volatility, and when bidder volatility is lower than target volatility

\begin{tabular}{|c|c|c|}
\hline & $\begin{array}{l}\text { Bidder idiosyncratic } \\
\text { volatility is higher } \\
\text { than target } \\
\text { idiosyncratic volatility }\end{array}$ & $\begin{array}{c}\text { Bidder idiosyncratic } \\
\text { volatility is lower than } \\
\text { target idiosyncratic } \\
\text { volatility }\end{array}$ \\
\hline Dependent variable: M\&A premiums (S\&P adjusted) & PRE_SP & PRE_SP \\
\hline \multirow[t]{2}{*}{ Bidder idiosyncratic volatility * Cash } & $-2.611 * *$ & 2.572 \\
\hline & $(-3.09)$ & $(1.00)$ \\
\hline \multirow[t]{2}{*}{ Target idiosyncratic volatility } & $7.169 * * *$ & $7.260^{*}$ \\
\hline & $(3.84)$ & $(1.99)$ \\
\hline \multirow[t]{2}{*}{ Bidder idiosyncratic volatility } & 0.537 & -2.359 \\
\hline & $(0.81)$ & $(-1.10)$ \\
\hline \multirow[t]{2}{*}{ Target $R \& D$ to market value } & 0.497 & $1.244 * * *$ \\
\hline & $(1.54)$ & $(4.50)$ \\
\hline \multirow[t]{2}{*}{ Target $R \& D$ to sales } & -0.00881 & 0.0000881 \\
\hline & $(-0.50)$ & $(0.09)$ \\
\hline \multirow[t]{2}{*}{ Target R\&D growth } & -0.00603 & -0.0121 \\
\hline & $(-0.38)$ & $(-0.71)$ \\
\hline \multirow[t]{2}{*}{ Target organizational flexibility } & $0.0267 *$ & -0.0372 \\
\hline & $(2.41)$ & $(-1.39)$ \\
\hline \multirow[t]{2}{*}{ Target financial flexibility (leverage) } & 0.148 & 0.0885 \\
\hline & $(1.65)$ & $(0.46)$ \\
\hline \multirow[t]{2}{*}{ Target financial flexibility (cashflow coverage) } & 0.0227 & -0.0447 \\
\hline & $(0.89)$ & $(-1.60)$ \\
\hline \multirow[t]{2}{*}{ Target sales growth } & $-0.000106^{*}$ & $-0.000341 * * *$ \\
\hline & $(-2.08)$ & $(-4.73)$ \\
\hline \multirow[t]{2}{*}{ Bidder R\&D to market value } & 0.00235 & $0.0119 *$ \\
\hline & $(0.31)$ & $(2.12)$ \\
\hline \multirow[t]{2}{*}{ Bidder R\&D to sales } & -0.0145 & -0.0183 \\
\hline & $(-0.20)$ & $(-0.43)$ \\
\hline \multirow[t]{2}{*}{ Bidder R\&D growth } & 0.000894 & 0.0356 \\
\hline & $(0.67)$ & $(1.93)$ \\
\hline \multirow[t]{2}{*}{ Industry relatedness } & 0.0163 & $-0.0502 *$ \\
\hline & $(0.56)$ & $(-2.12)$ \\
\hline \multirow[t]{2}{*}{ Financial synergy } & 0.000129 & 0.000635 \\
\hline & $(0.76)$ & $(0.31)$ \\
\hline \multirow[t]{2}{*}{ Relative size (sales) } & 0.0137 & $-0.0133 *$ \\
\hline & $(1.34)$ & $(-2.12)$ \\
\hline \multirow[t]{2}{*}{ Number of competing bids } & $0.198 * *$ & $0.203 * * *$ \\
\hline & $(3.18)$ & $(4.48)$ \\
\hline
\end{tabular}




\begin{tabular}{|c|c|c|}
\hline \multirow[t]{2}{*}{ Cash } & 0.0614 & 0.0264 \\
\hline & $(1.48)$ & $(0.59)$ \\
\hline \multirow[t]{2}{*}{ Stock } & -0.0505 & 0.0388 \\
\hline & $(-1.78)$ & $(1.43)$ \\
\hline \multirow[t]{2}{*}{ Tender offer } & $0.111 * *$ & $0.143 * * *$ \\
\hline & $(3.08)$ & $(5.13)$ \\
\hline \multirow[t]{2}{*}{ Merger of equal } & $-0.213 * *$ & $-0.328 * * *$ \\
\hline & $(-2.84)$ & $(-5.07)$ \\
\hline \multirow[t]{2}{*}{ Deal size } & 0.0304 & $0.0781 *$ \\
\hline & $(0.87)$ & $(2.07)$ \\
\hline \multirow[t]{2}{*}{ Hostile acquisition } & 0.0307 & 0.0104 \\
\hline & $(0.24)$ & $(0.16)$ \\
\hline \multirow[t]{2}{*}{ Number of days to effective } & $0.0000929 *$ & 0.000191 \\
\hline & $(2.09)$ & (1.74) \\
\hline \multirow[t]{2}{*}{ Target resistance to takeover } & 0.0862 & 0.0457 \\
\hline & $(0.56)$ & $(0.56)$ \\
\hline \multirow[t]{2}{*}{ Target business risk } & 1.548 & -2.603 \\
\hline & $(0.55)$ & $(-0.45)$ \\
\hline \multirow[t]{2}{*}{ Target firm size (sales) } & -0.0499 & $-0.106^{*}$ \\
\hline & $(-1.73)$ & $(-2.48)$ \\
\hline \multirow[t]{2}{*}{ Target market to book ratio } & -0.0000917 & $-0.000281^{*}$ \\
\hline & $(-0.14)$ & $(-2.16)$ \\
\hline \multirow[t]{2}{*}{ Target ROA } & 0.00118 & $0.00106^{*}$ \\
\hline & $(0.94)$ & $(2.52)$ \\
\hline \multirow[t]{2}{*}{ Target ROE } & 0.0000348 & -0.00000391 \\
\hline & (1.96) & $(-0.09)$ \\
\hline \multirow[t]{2}{*}{ Target operating cashflow } & $-0.0316^{*}$ & -0.000892 \\
\hline & $(-2.43)$ & $(-0.62)$ \\
\hline \multirow[t]{2}{*}{ Target financial independence } & 0.124 & -0.00330 \\
\hline & $(1.58)$ & $(-0.04)$ \\
\hline \multirow[t]{2}{*}{ Target debt to equity } & -0.0000669 & -0.000752 \\
\hline & $(-0.11)$ & $(-0.36)$ \\
\hline \multirow[t]{2}{*}{ Public bidder } & $0.260 * * *$ & 0.134 \\
\hline & $(7.13)$ & $(1.30)$ \\
\hline \multirow[t]{2}{*}{ Target shares owned by bidder before M\&A } & -0.159 & 0.0336 \\
\hline & $(-1.75)$ & $(0.33)$ \\
\hline \multirow[t]{2}{*}{ Target shares owned by bidder after M\&A } & $0.351 * * *$ & $0.438 * * *$ \\
\hline & $(6.05)$ & $(5.84)$ \\
\hline \multirow[t]{2}{*}{ _cons } & $-0.540 * * *$ & $-0.396 *$ \\
\hline & $(-4.28)$ & $(-2.14)$ \\
\hline $\mathbf{N}$ & 792 & 1395 \\
\hline adj.R-sq & 0.235 & 0.213 \\
\hline $\begin{array}{l}\text { t statistics in parentheses } \\
* \mathbf{p}<0.05, * * \mathbf{p}<0.01, * * * \mathbf{p}<0.001\end{array}$ & & \\
\hline
\end{tabular}




\subsection{Robustness Test}

In order to ensure that our results are robust to alternative measures of M\&A premiums, we conduct some additional robustness tests. We replace M\&A premiums adjusted for S\&P 500 by the total M\&A premiums. Then, we run the regressions with idiosyncratic volatility, and total volatility as well as different measures of firm size. We also run the regressions for three subsamples, which are pure stock, pure cash, and mix. The results produce no significant change. (See Appendix B, Appendix C, Appendix D, and Appendix E) 


\section{CHAPTER 5}

\section{DISCUSSION}

In this section, we discuss the results and explain our findings. Since the results for idiosyncratic volatility and total volatility are not significantly different, the term return volatility is stood for both idiosyncratic volatility and total volatility.

\subsection{Full Sample}

After investigating the influence of stock return volatility on M\&A premiums by using real options approach, we find that the positive relationship between acquisition premiums and target stock return volatility is stronger for target firms that have more future growth options. To be more specific, after we include the interaction terms between volatility and real option variables, real option variables and target stock return volatility alone are no longer related to M\&A premiums. The interaction variable between target return volatility and target $R \& D$ to market value is positively correlated with M\&A premiums. So, the positive relationship between M\&A premiums and stock return volatility of target firm is stronger when target firm have higher R\&D to market value ratio. Concerning the target sales growth rate, after including the interaction term, the interaction variable between target stock return volatility and target sales growth is positively related with M\&A premium. This result reveals that takeover premium is significantly larger when target firms have more sales growth and more risk. These findings are consistent with the real option hypothesis since return volatility, $R \& D$ to market value and sales growth rate have a positive effect on growth option of a firm (Trigeorgis \& Lambertides, 2014). Thus, the positive relationship between acquisition premiums and target stock return volatility is stronger for target 
firms that have more future growth options. In other word, bidder firms pay high premiums for the targets with high risk and high real option value with the expectation of high return in the future.

Before we add the interaction terms to the models, we find that both total return volatility and idiosyncratic volatility of targets are positively correlated with M\&A premium in full sample. This finding is consistent with Chatterjee et al. (2012) and Zhu et al. (2014), both of which use asymmetric information theory and diversity of investor opinion to explain the results. After we include the interaction terms, the idiosyncratic volatility variable of the target is no more significant in full sample and cash sample. The interaction terms are significant. Thus, the positive relationship between acquisition premiums and idiosyncratic volatility of targets is due to the real option value of the target, is possibly not due to the asymmetric information theory.

Without the interaction terms, the target $R \& D$ to market value has a positive relationship with acquisition premiums. This result is consistent with the finding of Laamanen (2007). Target sales growth are negatively correlated with M\&A premiums, which differs from the finding of Laamanen (2007). Target financial flexibility measured as cashflows coverage and acquisition premiums have the negative relationship, which is in line with the growth option model of Trigeorgis and Lambertides (2014). The results reveal that without considering the interaction between target volatility and real option variables, higher M\&A premiums are associated with higher stock return volatility, greater target M\&A to market value, lower cash flows coverage of the target, and lower target sales growth rate. 


\subsection{Stock deals sample}

In stock deals, we reveal that the positive relationship between stock return volatility of the target firms and acquisition premiums is stronger when the target firms have less leverage ratio. The result can be explained by the real option value of the targets. After adding the interaction terms between target volatility and real option variables to the model, target return volatility, target R\&D to market value, and target leverage ratio are positively related to M\&A premiums. The interaction variable between target leverage ratio and target return volatility is negatively correlated with acquisition premiums. This negative relationship shows that the takeover premium is higher when a company has less leverage ratio and high return volatility. Trigeorgis and Lambertides (2014) reveal that leverage ratio is negatively related to growth option value of a firm because, in order to have debt, firm need tangible assets to use as the collateral. Furthermore, firms with high future growth options have less tangible assets. So, the positive relationship between stock return volatility of the target firms and acquisition premiums is stronger when the target firms have less leverage ratio or equivalently more real options.

Before adding the interaction terms, we find that there is a positive relationship between idiosyncratic return volatility of the targets and acquisition premiums. However, when we use total return volatility, the relationship between total volatility and M\&A premium is insignificant. Thus, idiosyncratic volatility is a better measure of volatility. Some real option variables affect M\&A premiums significantly, such as target $R \& D$ to market value and target financial flexibility measured as leverage is positively correlated with acquisition premiums. Furthermore, higher R\&D to sales of the target firms is associated with lower M\&A premiums. Hence, in the stock deals, without the interaction terms, higher M\&A premiums are associated with higher target 
idiosyncratic volatility, higher target $R \& D$ to market value, lower target $R \& D$ to sales, greater target leverage ratio.

\subsection{Cash deals samples}

In the pure cash deals, the acquisition premiums are significantly larger when target firms have more $R \& D$ investment to market value ratio and more risk. After including the interaction variables between target return volatility and target real option variables, only the interaction term between target R\&D to market value and target stock return volatility shows a positive relationship. This finding can be explained by using the real options theory. The bidder firm will pay high premiums for target firms with high growth option and the positive relationship between acquisition premiums and target stock return volatility is significantly stronger when target firms have more $R \& D$ investment to market value ratio.

Before we include the interaction terms, the stock return volatility of the target is positively correlated with acquisition premiums, which is consistent with previous literature (Chatterjee et al., 2012; Zhu et al., 2014). In contrast, the stock return volatility of the bidder and M\&A premium have a negative relationship. As regards the real option variables of the targets, higher acquisition premiums are associated with higher R\&D to market value. This finding is in line with the finding of Laamanen (2007). Furthermore, we reveal that financial flexibility measured as leverage ratio and M\&A premiums are positively related. Concerning the growth option variables of the bidder, only R\&D to market value is positively correlated with M\&A premiums. The result for bidder growth option variable is not strong, because it only appears in cash deals sample when we measure firm size as assets. 


\subsection{Results of bidder volatility in cash deals}

We reveal that when the bidder volatility is higher than target volatility, the bidder firms tend to pay less cash M\&A premiums when they have high risk. The reason is that when the shareholders of the target expect that the bidder will have higher risk. They are more likely to reject the deal. In our sample, we only include the completed deals. So, when the target shareholders see the deal is coming through, they are more likely to take a smaller cash premium and leave. This is because they do not want to be the shareholders of the risky firm. The negative relationship between bidder volatility and bidder $R \& D$ to market value ratio is not related to real options theory. Because after we include the interaction terms between bidder return volatility and growth option variables of the bidders, the results for the interaction term is insignificant. Thus, the negative relationship between bidder volatility and bidder $\mathrm{R} \& \mathrm{D}$ to market value ratio is not related to real options theory but related to the ratio of bidder and target volatility.

\subsection{Results of control variables}

\subsubsection{Synergy effect variables}

There are three types of synergy effect, which are financial synergy, relative size, and industry relatedness. We find that higher financial synergy is related to higher acquisition premiums in mix deals and negative relationship in cash deals. Consistent with previous literature, we reveal that the higher relative size between target and bidder, the lower acquisition premiums (Chatterjee et al., 2012; Jindra \& Moeller, 2015; Moeller, 2005). Consistent with some previous research papers, we find that there is no significant relationship between industry relatedness and M\&A premiums (Haunschild, 1994; Hayward \& Hambrick, 1997). 


\subsubsection{Deal characteristic variables}

Acquisition premiums are higher in the deals that have more than one competing bidder. This finding is consistent with various previous studies (Giliberto \& Varaiya, 1989; Haunschild, 1994; Hayward \& Hambrick, 1997; Jahera et al., 1985; Shelton, 2000; Slusky \& Caves, 1991; Varaiya, 1988; Varaiya \& Ferris, 1987; Walkling \& Edmister, 1985; Zhu et al., 2014). The tender offer deals have more acquisition premiums than other deals. This result is in line with Chatterjee et al. (2012), Jindra and Moeller (2015), and Zhu et al. (2014). Also, consistent with Laamanen (2007), the acquisition premiums are lower in the merger of equals deals. Concerning the deal size, we find that the larger of the deal size, the higher of M\&A premiums. This result is similar to the finding of Zhu et al. (2014). Furthermore, The M\&A premiums and hostile takeover have a positive relationship, which is consistent with several previous papers (Chatterjee et al., 2012; Jindra \& Moeller, 2015; Servaes, 1991; Sudarsanam \& Sorwar, 2010). Moeller (2005) finds that there is no significant relationship between the number of days to effective variable and acquisition premiums. Yet, we reveal that the more days to effective, the higher acquisition premiums.

\subsubsection{Targets characteristic variables}

We find that the higher target business risk, the greater acquisition premiums. This result is consistent with the finding of Lambrecht (2004) and Sudarsanam and Sorwar (2010). Furthermore, bidder firms pay more M\&A premiums to acquire the target firms that have a small size. The result is consistent with several previous research papers (Bange, 2004; Chan et al., 2001; Chatterjee et al., 2012; Schwert, 2000; Zhu et al., 2014). We find that the higher target ROA, the higher acquisition premiums in full sample and stock sample. Some researchers investigate the effect of ROA of targets on M\&A premium, yet find the insignificant results (Bauguess et al., 2009; Jindra \& Moeller, 2015). Additionally, we reveal that the higher ROE of target firms, the 
lower M\&A premiums in cash deals sample. Consistent with Bauguess et al. (2009), we find that bidder firms pay more acquisition premiums for the targets that have high operating cash flow. As opposed to Walkling and Edmister (1985), we find that higher target debt to equity, higher M\&A premiums in cash deal. In mix deal, the target debt to equity ratio and acquisition premiums has the negative relationship, which is consistent with the finding of Walkling and Edmister (1985)

\subsubsection{Bidder characteristic variables}

Consistent with Zhu et al. (2014), the M\&A premiums are higher when the acquirers are the public firms. The target shares owned by the bidder before the acquisition announcement is negatively correlated with acquisition premiums. This result is consistent with the finding of Betton and Eckbo (2000) and Chatterjee et al. (2012). Furthermore, we reveal that the larger target shares owned by the bidder after M\&A announcement, the greater acquisition premiums. 


\section{CHAPTER 6}

\section{CONCLUSION AND RECOMMENDATION}

This study aims to understand the effect of stock return volatility on M\&A premium based on real option value of target firms. In this chapter, we summarize the findings of this research, offer conclusion based on the finding and recommend some directions for future research.

\subsection{Conclusions}

This thesis studies the how stock return volatility affects acquisition premiums through real option values contained in the bidder and target firm in the U.S from 1986 to 2016 . We reveal that when targets have more real options measured as high $R \& D$ to market value, large sales growth rate, and low leverage ratio, the relationship between target return volatility and M\&A premiums tend to be stronger. In other words, bidder firms tend to pay more premiums for the target firms that have more future real option value and higher risk. These results apply not only in full sample but also in pure stock and pure cash sub-sample.

The results of this study are consistent with previous research papers about the positive effect of idiosyncratic volatility on M\&A premiums (Chatterjee et al., 2012; Zhu et al., 2014). Chatterjee et al. (2012) and Zhu et al. (2014) use asymmetric information theory to explain the results. In our research, after adding the interaction terms between volatility and real option variables, the positive relationship between acquisition premiums and target return volatility alone is insignificant, yet interaction terms are significant. Thus, using real options theory to explain the positive relationship between M\&A premiums and stock return volatility seems to be a more logical explanation. 
When the bidder volatility is higher than target volatility, the bidder firms tend to pay fewer cash premiums when they have more risk. This is because when the target shareholders expect the merged entity will have higher risk, they are more likely to reject the deal. If they see the deal is coming through (in our sample, all the failed deals are not included), they are more likely to take a smaller cash premium and leave.

\subsection{Recommendation and Proposed Further Research}

Some extensions to our research can be considered for future research. First, it may be interesting to test the effect of high volatility and high real option value of the target firm on the return of the bidder firm after M\&A announcement. So that we can figure out if the bidder firms pay high premiums for the targets that have high risk and high real option value, the shareholder will receive high or low return in the future. Second, future research paper could focus on other markets, for instance, UK or Asia.

We also have some suggestions to eliminate the limitation of this thesis. Firstly, when we use market value to measure firm size, the results are not reliable because there is an endogeneity problem in the model with market value. Two-stage least square should be used to run the model with firm size measured as market value in future research. Secondly, we suggest that further research could spend more time to fix the CUSIP issue. Because of the difficulty in matching the CUSIP 6 digits, CUSIP 8 digits, and CUSIP 9 digits, approximately 10 percent of observations are dropped in our sample. 


\section{APPENDIX}

\section{Appendix A. Variable measurement and data source}

\begin{tabular}{|c|c|c|}
\hline Variable name & Measurement & Data sources \\
\hline M\&A premium with S\&P adjustment & $\begin{array}{l}\text { The difference between the adjusted } \\
\text { initial offer price and the market } \\
\text { price one month before } \\
\text { announcement date. The initial offer } \\
\text { price for the acquisition is adjusted } \\
\text { for the change in the S\&P } 500 \text { index } \\
\text { during one-month prior } \\
\text { announcement. }\end{array}$ & $\begin{array}{l}\text { SDC Mergers and } \\
\text { Acquisitions } \\
\text { database }\end{array}$ \\
\hline M\&A Premium & $\begin{array}{l}\text { The difference between the price } \\
\text { offered by the bidder and the pre- } \\
\text { announcement stock price of the } \\
\text { target company, divided by the pre- } \\
\text { announcement stock price of the } \\
\text { target company }\end{array}$ & $\begin{array}{l}\text { SDC Mergers and } \\
\text { Acquisitions } \\
\text { database }\end{array}$ \\
\hline Idiosyncratic volatility & $\begin{array}{l}\text { We run regressions of Fama-French } \\
\text { three factors model for each } \\
\text { company during the period of } 252 \\
\text { trading days before acquisition } \\
\text { announcement to get the residuals } \\
\text { of the model. The square roots of the } \\
\text { residuals form the Fama-French } \\
\text { three-factor model divided by } 251 \\
\text { are the idiosyncratic risk of the } \\
\text { company. }\end{array}$ & CRSP \\
\hline Total volatility & $\begin{array}{l}\text { The standard deviation of the stock } \\
\text { return for each firm during } 252 \\
\text { trading days prior to acquisition } \\
\text { announcement }\end{array}$ & CRSP \\
\hline R\&D to market value & $\begin{array}{l}\text { R\&D expense to market value of } \\
\text { equity }\end{array}$ & Compustat \\
\hline R\&D to sales & $\begin{array}{l}\text { The recent 3-years period R\&D } \\
\text { investment to sales }\end{array}$ & Compustat \\
\hline R\&D growth & $\begin{array}{l}\text { The average R\&D investment growth } \\
\text { rate of the target firms during the } \\
\text { three years before the acquisitions } \\
\text { announcement }\end{array}$ & Compustat \\
\hline Organizational flexibility & $\begin{array}{l}\text { The ratio of selling, general, and } \\
\text { administrative (SGA) expenses to } \\
\text { sales of target firm }\end{array}$ & Compustat \\
\hline
\end{tabular}




\begin{tabular}{|c|c|c|}
\hline Financial flexibility (leverage) & $\begin{array}{l}\text { The ratio of total debt and total } \\
\text { assets one year before M\&A } \\
\text { announcement }\end{array}$ & Compustat \\
\hline $\begin{array}{l}\text { Financial flexibility (cashflow } \\
\text { coverage) }\end{array}$ & $\begin{array}{l}\text { the ratio of operating cash flows and } \\
\text { total debt of the firm in a fiscal year } \\
\text { before the acquisition } \\
\text { announcement }\end{array}$ & Compustat \\
\hline Sales growth & $\begin{array}{l}\text { The average growth rate of the firm } \\
\text { sales during } 3 \text { years before } \\
\text { acquisition announcement }\end{array}$ & Compustat \\
\hline Industry relatedness & $\begin{array}{l}\text { Dummy variable which equals } 1 \\
\text { when bidder and target share two } \\
\text { first digits SIC codes, otherwise } 0\end{array}$ & $\begin{array}{l}\text { SDC Mergers and } \\
\text { Acquisitions } \\
\text { database }\end{array}$ \\
\hline Financial synergy & $\begin{array}{l}\text { Debt to equity ratio of target and } \\
\text { bidder firm in one year before } M \& A \\
\text { announcement }\end{array}$ & Compustat \\
\hline Relative size (sales) & $\begin{array}{l}\text { The total sales of target to total sales } \\
\text { of bidder at the last fiscal-year end } \\
\text { before acquisition announcement }\end{array}$ & Compustat \\
\hline Relative size (assets) & $\begin{array}{l}\text { The total assets of target to total } \\
\text { assets of bidder at the last fiscal-year } \\
\text { end before acquisition } \\
\text { announcement }\end{array}$ & Compustat \\
\hline Relative size (market value) & $\begin{array}{l}\text { The market value of target to market } \\
\text { value of bidder } 4 \text { weeks before } \\
\text { acquisition announcement }\end{array}$ & CRSP \\
\hline Number of competing bids & $\begin{array}{l}\text { Dummy variable which equals } 1 \text { if } \\
\text { M\&A deal have one or more than } \\
\text { one competing bidders, otherwise } 0\end{array}$ & $\begin{array}{l}\text { SDC Mergers and } \\
\text { Acquisitions } \\
\text { database }\end{array}$ \\
\hline Method of payment (cash) & $\begin{array}{l}\text { Dummy variable which equals } 1 \text { if } \\
\text { the acquisition paid in pure cash, } \\
\text { otherwise } 0\end{array}$ & $\begin{array}{l}\text { SDC Mergers and } \\
\text { Acquisitions } \\
\text { database }\end{array}$ \\
\hline Method of payment (stock) & $\begin{array}{l}\text { Dummy variable which equals } 1 \text { if } \\
\text { the acquisition paid in pure Stock, } \\
\text { otherwise } 0\end{array}$ & $\begin{array}{l}\text { SDC Mergers and } \\
\text { Acquisitions } \\
\text { database }\end{array}$ \\
\hline Method of payment (mix) & $\begin{array}{l}\text { Dummy variable which equals } 1 \text { if } \\
\text { the acquisition paid in mix of cash } \\
\text { and stock, otherwise } 0\end{array}$ & $\begin{array}{l}\text { SDC Mergers and } \\
\text { Acquisitions } \\
\text { database }\end{array}$ \\
\hline Method of payment (other) & $\begin{array}{l}\text { Dummy variable which equals } 1 \text { if } \\
\text { the acquisition paid in other } \\
\text { methods, otherwise } 0\end{array}$ & $\begin{array}{l}\text { SDC Mergers and } \\
\text { Acquisitions } \\
\text { database }\end{array}$ \\
\hline Tender offer & $\begin{array}{l}\text { Dummy variable which equals } 1 \text { for } \\
\text { deals with the tender offer, and } 0 \text { for } \\
\text { otherwise }\end{array}$ & $\begin{array}{l}\text { SDC Mergers and } \\
\text { Acquisitions } \\
\text { database }\end{array}$ \\
\hline
\end{tabular}




\begin{tabular}{|c|c|c|}
\hline Merger of equal & $\begin{array}{l}\text { Dummy variable which equals } 1 \text { for } \\
\text { deals with mergers of equals, and } 0 \\
\text { for otherwise }\end{array}$ & $\begin{array}{l}\text { SDC Mergers and } \\
\text { Acquisitions } \\
\text { database }\end{array}$ \\
\hline Deal size & $\begin{array}{l}\text { Log of acquisition transaction deal } \\
\text { value }\end{array}$ & $\begin{array}{l}\text { SDC Mergers and } \\
\text { Acquisitions } \\
\text { database }\end{array}$ \\
\hline Hostile acquisition & $\begin{array}{l}\text { Dummy variable which equals } 1 \text { for } \\
\text { hostile deals, and } 0 \text { for friendly deals }\end{array}$ & $\begin{array}{l}\text { SDC Mergers and } \\
\text { Acquisitions } \\
\text { database }\end{array}$ \\
\hline Number of days to effective & $\begin{array}{l}\text { The difference between the effective } \\
\text { date and the announcement date of } \\
\text { M\&A deal }\end{array}$ & $\begin{array}{l}\text { SDC Mergers and } \\
\text { Acquisitions } \\
\text { database }\end{array}$ \\
\hline Target resistance to takeover & $\begin{array}{l}\text { Dummy variable which equals } 1 \text { for } \\
\text { firms with a poison pill and } 0 \text { for } \\
\text { firms without a poison pill }\end{array}$ & $\begin{array}{l}\text { SDC Mergers and } \\
\text { Acquisitions } \\
\text { database }\end{array}$ \\
\hline Target business risk & $\begin{array}{l}\text { The product of return volatility of } \\
\text { target firm } 252 \text { days before } \\
\text { announcement and the difference } \\
\text { between } 1 \text { and target leverage ratio } \\
\text { in one year before announcement }\end{array}$ & CRSP and Compustat \\
\hline Target firm size (sales) & $\begin{array}{l}\text { Log of total sales } 1 \text { year before } \\
\text { announcement }\end{array}$ & Compustat \\
\hline Target firm size (assets) & $\begin{array}{l}\text { Log of total assets } 1 \text { year before } \\
\text { announcement }\end{array}$ & Compustat \\
\hline Target firm size (market value) & $\begin{array}{l}\text { Log of total market value } 4 \text { weeks } \\
\text { before announcement }\end{array}$ & Compustat \\
\hline Target market to book ratio & $\begin{array}{l}\text { The ratio of market value of the } \\
\text { acquired firm } 4 \text { weeks prior to } \\
\text { takeover announcement and book } \\
\text { value of target firm in the last fiscal } \\
\text { year before M\&A announcement }\end{array}$ & Compustat \\
\hline Target ROA & $\begin{array}{l}\text { The ratio of net income and total } \\
\text { asset of target firm in the last fiscal } \\
\text { year prior to acquisition } \\
\text { announcement }\end{array}$ & Compustat \\
\hline Target ROE & $\begin{array}{l}\text { The ratio of net income and } \\
\text { shareholder's equity of target firm in } \\
\text { the last fiscal year prior to } \\
\text { acquisition announcement }\end{array}$ & Compustat \\
\hline
\end{tabular}




\begin{tabular}{|l|l|l|}
\hline Target operating cashflow & $\begin{array}{l}\text { The ratio of operating cash flows and } \\
\text { sales of target firm in one fiscal year } \\
\text { before acquisition announcement }\end{array}$ & Compustat \\
\hline Target financial independence & $\begin{array}{l}\text { The difference between cash in two } \\
\text { years before announcement and } \\
\text { operating cash flows in one year } \\
\text { before acquisition announcement } \\
\text { divided by target total assets in one } \\
\text { year before announcement }\end{array}$ & Compustat \\
\hline Target debt to equity & $\begin{array}{l}\text { The total debt is divided by total } \\
\text { equity of target firm 1 year before } \\
\text { announcement }\end{array}$ & Compustat \\
\hline Public bidder & $\begin{array}{l}\text { Dummy variable which equals 1 if } \\
\text { the bidder firms is listed publicly, } \\
\text { otherwise 0 }\end{array}$ & Compustat \\
\hline $\begin{array}{l}\text { Target shares owned by bidder } \\
\text { before M\&A }\end{array}$ & $\begin{array}{l}\text { The percentage of target's share held } \\
\text { by bidder before M\&A } \\
\text { announcement }\end{array}$ & $\begin{array}{l}\text { SDC Mergers and } \\
\text { Acquisitions } \\
\text { database }\end{array}$ \\
\hline $\begin{array}{l}\text { Target shares owned by bidder after } \\
\text { M\&A }\end{array}$ & $\begin{array}{l}\text { The percentage of target's share held } \\
\text { by bidder after M\&A announcement }\end{array}$ & $\begin{array}{l}\text { SDC Mergers and } \\
\text { Acquisitions } \\
\text { database }\end{array}$ \\
\hline
\end{tabular}


Appendix B. Regression results of M\&A premiums, idiosyncratic volatility, and real option variables

\begin{tabular}{|c|c|c|c|c|c|c|c|c|c|c|c|c|}
\hline & \multicolumn{4}{|c|}{ Sales } & \multicolumn{4}{|c|}{ Assets } & \multicolumn{4}{|c|}{ Market value } \\
\hline & (1) & (2) & (3) & (4) & (5) & (6) & (7) & (8) & (9) & (10) & (11) & (12) \\
\hline $\begin{array}{l}\text { Dependent variable: M\&A } \\
\text { premiums }\end{array}$ & Full & Cash & Stock & Mix & Full & Cash & Stock & Mix & Full & Cash & Stock & Mix \\
\hline \multirow[t]{2}{*}{ Target idiosyncratic volatility } & $5.778^{*}$ & $7.698 * * *$ & $3.789 *$ & -3.190 & 4.366 & $6.906^{* * *}$ & 0.499 & -2.654 & 2.821 & $6.608^{* * *}$ & -0.779 & 1.505 \\
\hline & $(2.20)$ & $(4.87)$ & $(2.30)$ & $(-0.68)$ & (1.64) & $(4.28)$ & $(0.31)$ & $(-0.67)$ & $(1.20)$ & $(4.57)$ & $(-0.91)$ & $(0.52)$ \\
\hline Bidder idiosyncratic volatility & $(-0.90)$ & $(-3.87)$ & $(-0.24)$ & (1.96) & $(-1.58)$ & $(-3.56)$ & $(-1.27)$ & (1.73) & $(-0.76)$ & $(-3.89)$ & $(-0.72)$ & (1.89) \\
\hline \multirow[t]{2}{*}{ Target R\&D to market value } & $1.120 * * *$ & $1.259 * * *$ & $1.722 * * *$ & 0.481 & $1.102^{* * *}$ & $1.296 * * *$ & $1.562^{* * *}$ & 0.441 & $1.006 * * *$ & $1.228^{* * *}$ & 0.260 & -0.154 \\
\hline & $(5.11)$ & (3.78) & (3.64) & $(0.68)$ & $(4.97)$ & (3.92) & $(3.46)$ & $(0.64)$ & $(4.92)$ & (3.86) & $(1.32)$ & $(-0.28)$ \\
\hline \multirow[t]{2}{*}{ Target R\&D to sales } & 0.000622 & 0.0000788 & $-0.0165^{*}$ & 0.0811 & 0.000886 & -0.000144 & -0.00997 & 0.0180 & 0.000737 & 0.0000200 & -0.00512 & 0.0397 \\
\hline & $(0.75)$ & $(0.13)$ & $(-2.47)$ & $(1.36)$ & $(0.90)$ & $(-0.25)$ & $(-1.46)$ & $(0.34)$ & $(0.84)$ & $(0.04)$ & $(-1.93)$ & $(1.03)$ \\
\hline Target R\&D growth & 0.000961 & -0.0141 & -0.0113 & 0.0425 & 0.00238 & -0.0160 & 0.000962 & 0.0605 & 0.00656 & -0.0106 & 0.000225 & 0.0313 \\
\hline \multirow[t]{2}{*}{ Target organizational flexibility } & -0.00420 & 0.00655 & -0.00909 & 0.0477 & -0.00403 & -0.0185 & -0.00635 & 0.0218 & -0.00500 & 0.00515 & -0.00336 & 0.0675 \\
\hline & $(-0.86)$ & $(0.16)$ & $(-0.39)$ & $(0.37)$ & $(-0.80)$ & $(-0.46)$ & $(-0.29)$ & $(0.17)$ & $(-1.26)$ & $(0.13)$ & $(-0.38)$ & $(0.90)$ \\
\hline \multirow[t]{2}{*}{$\begin{array}{l}\text { Target financial flexibility } \\
\text { (leverage) }\end{array}$} & 0.0742 & 0.123 & 0.198 & 0.310 & 0.208 & $0.182^{*}$ & $0.521 * * *$ & $0.344^{*}$ & 0.0678 & 0.122 & 0.0848 & 0.0791 \\
\hline & $(0.57)$ & $(1.64)$ & $(1.74)$ & $(1.91)$ & $(1.53)$ & $(2.35)$ & $(4.04)$ & $(1.99)$ & $(0.55)$ & $(1.67)$ & $(1.67)$ & $(0.56)$ \\
\hline \multirow[t]{2}{*}{$\begin{array}{l}\text { Target financial flexibility } \\
\text { (cashflow coverage) }\end{array}$} & -0.0371 & 0.00614 & -0.0124 & -0.0273 & $-0.0558 * *$ & 0.00175 & -0.0484 & -0.0616 & $-0.0384 *$ & -0.00140 & -0.00366 & -0.00477 \\
\hline & $(-1.91)$ & $(0.20)$ & $(-0.41)$ & $(-0.30)$ & $(-2.77)$ & $(0.06)$ & $(-1.70)$ & $(-0.76)$ & $(-2.18)$ & $(-0.05)$ & $(-0.44)$ & $(-0.08)$ \\
\hline \multirow[t]{2}{*}{ Target sales growth } & $-0.00015^{* *}$ & -0.00548 & -0.0000393 & 0.00154 & $-0.0002 * * *$ & -0.00650 & -0.000100 & -0.00285 & $-0.00016^{* *}$ & -0.00530 & -0.0000428 & -0.00018 \\
\hline & $(-3.15)$ & $(-1.10)$ & $(-0.47)$ & $(0.08)$ & $(-4.27)$ & $(-1.48)$ & $(-1.21)$ & $(-0.13)$ & $(-2.91)$ & $(-1.18)$ & $(-1.30)$ & $(-0.01)$ \\
\hline \multirow[t]{2}{*}{ Bidder R\&D to market value } & 0.00453 & 0.0115 & 0.0102 & -0.00237 & 0.00421 & $0.0158^{*}$ & 0.00812 & 0.000522 & 0.00331 & 0.0102 & 0.00363 & 0.00838 \\
\hline & $(0.70)$ & (1.64) & $(1.36)$ & $(-0.21)$ & $(0.64)$ & $(2.16)$ & $(1.03)$ & $(0.04)$ & $(0.60)$ & $(1.60)$ & (1.54) & $(0.98)$ \\
\hline \multirow[t]{2}{*}{ Bidder R\&D to sales } & -0.00782 & -0.0986 & 0.0779 & 0.0700 & 0.00108 & -0.0875 & 0.0678 & 0.0749 & 0.00571 & -0.0840 & 0.0224 & 0.0414 \\
\hline & $(-0.23)$ & $(-1.48)$ & $(0.92)$ & (1.58) & $(0.03)$ & $(-1.38)$ & $(0.79)$ & (1.67) & $(0.20)$ & $(-1.22)$ & (0.69) & (1.25) \\
\hline Bidder R\&D growth & 0.00388 & 0.00409 & 0.00156 & -0.0467 & 0.00394 & 0.00347 & 0.00169 & -0.0565 & 0.00359 & 0.00278 & 0.000406 & -0.0253 \\
\hline
\end{tabular}




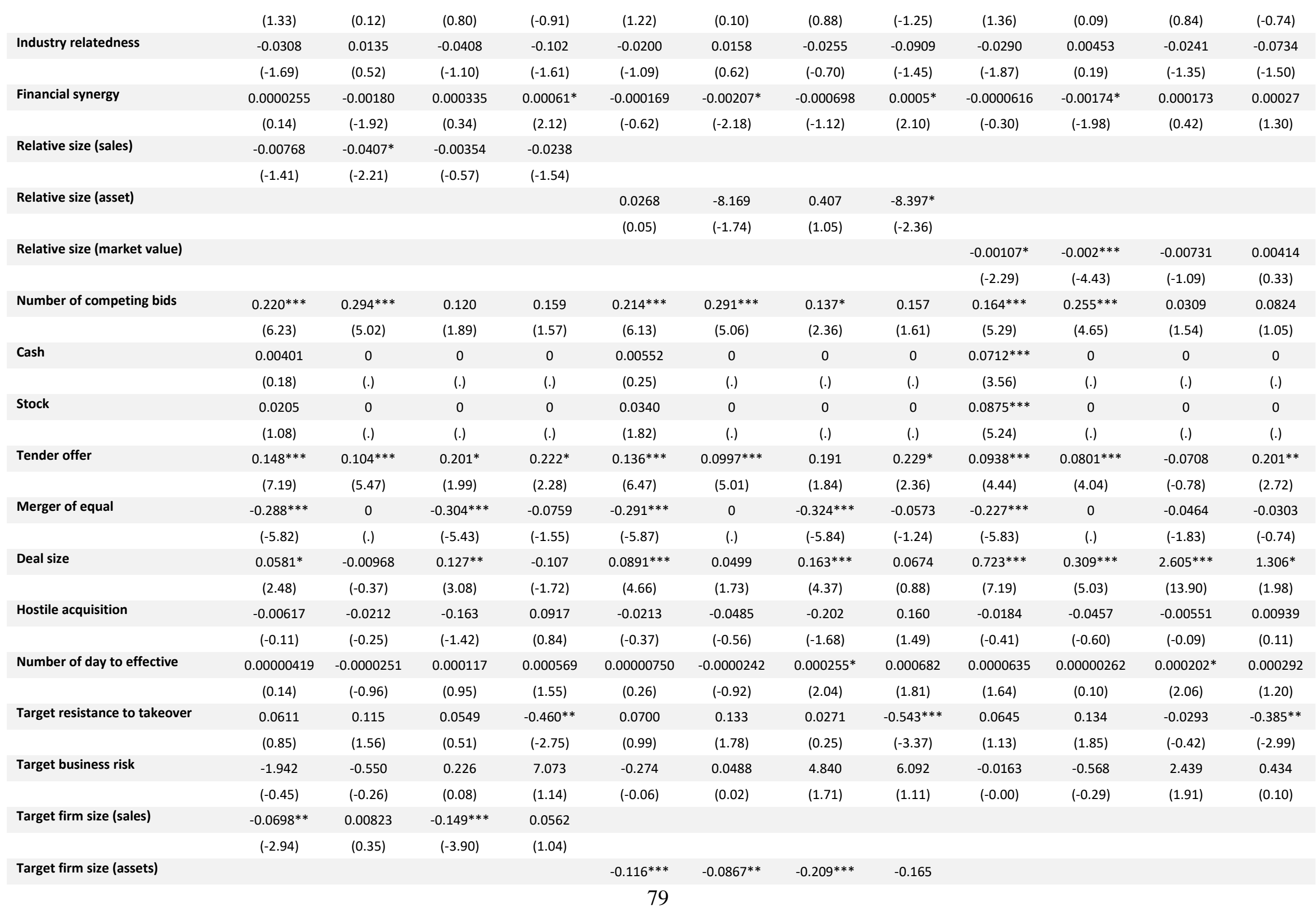




\begin{tabular}{|c|c|c|c|c|c|c|c|c|c|c|c|c|}
\hline & & & & & $(-5.83)$ & $(-2.83)$ & $(-5.70)$ & $(-1.91)$ & & & & \\
\hline \multirow[t]{2}{*}{ Target firm size (market value) } & & & & & & & & & $-0.733 * * *$ & $-0.328 * * *$ & $-2.613 * * *$ & $-1.323 *$ \\
\hline & & & & & & & & & $(-7.33)$ & $(-5.33)$ & $(-13.84)$ & $(-2.03)$ \\
\hline \multirow[t]{2}{*}{ Target market to book ratio } & $-0.0003 * *$ & $-0.00233^{*}$ & $-0.000808^{* *}$ & 0.000310 & $-0.000283^{* *}$ & $-0.00331 * *$ & $-0.000708^{*}$ & 0.000433 & $-0.000198^{*}$ & $-0.00182 *$ & $-0.000437 * * *$ & 0.000222 \\
\hline & $(-2.61)$ & $(-2.48)$ & $(-2.60)$ & $(1.37)$ & $(-2.87)$ & $(-2.72)$ & $(-2.21)$ & $(1.64)$ & $(-2.04)$ & $(-2.46)$ & $(-3.83)$ & (1.64) \\
\hline \multirow[t]{2}{*}{ Target ROA } & $0.000844^{*}$ & 0.00000588 & $0.00205^{*}$ & 0.00187 & $0.00105^{*}$ & -0.000122 & $0.00386^{* * *}$ & -0.000438 & 0.000473 & 0.000128 & -0.000400 & -0.000284 \\
\hline & $(2.16)$ & $(0.01)$ & $(2.09)$ & $(0.43)$ & $(2.56)$ & $(-0.23)$ & $(3.52)$ & $(-0.09)$ & $(1.13)$ & $(0.30)$ & $(-0.85)$ & $(-0.09)$ \\
\hline Target ROE & $(0.22)$ & $(-1.00)$ & $(1.16)$ & $(0.17)$ & $(0.09)$ & $(-2.65)$ & $(0.04)$ & $(0.63)$ & $(-0.04)$ & $(-0.90)$ & $(-0.63)$ & $(0.65)$ \\
\hline \multirow[t]{2}{*}{ Target operating cashflow } & -0.000590 & $-0.00910^{*}$ & 0.000214 & -0.00208 & -0.000356 & -0.00743 & $0.000851^{* * *}$ & -0.00550 & -0.000369 & $-0.00809 *$ & $0.000360 * * *$ & -0.00291 \\
\hline & $(-0.44)$ & $(-2.09)$ & $(1.11)$ & $(-0.50)$ & $(-0.25)$ & $(-1.71)$ & $(8.93)$ & $(-1.44)$ & $(-0.29)$ & $(-2.08)$ & $(6.07)$ & $(-1.06)$ \\
\hline \multirow[t]{2}{*}{ Target financial independence } & 0.0107 & -0.0485 & -0.0698 & -0.0874 & 0.0222 & -0.0256 & -0.0584 & -0.0175 & -0.0115 & -0.0345 & -0.0328 & -0.0131 \\
\hline & $(0.20)$ & $(-0.89)$ & $(-0.90)$ & $(-0.62)$ & $(0.45)$ & $(-0.49)$ & $(-0.76)$ & $(-0.12)$ & $(-0.26)$ & $(-0.67)$ & $(-1.04)$ & $(-0.14)$ \\
\hline Target debt to equity & 0.0000225 & $0.00321 *$ & -0.00149 & $-0.00618^{* *}$ & 0.000377 & $0.00545^{* * *}$ & 0.00108 & -0.00271 & 0.000131 & $0.00319 *$ & 0.000281 & -0.00178 \\
\hline \multirow[t]{2}{*}{ Public bidder } & 0.112 & 0.0941 & 0.103 & $0.219^{*}$ & $0.135^{*}$ & 0.0837 & 0.107 & $0.357^{* *}$ & 0.108 & 0.0954 & 0.0203 & $0.461 * * *$ \\
\hline & $(1.65)$ & $(0.65)$ & $(1.45)$ & $(2.25)$ & $(2.09)$ & $(0.59)$ & $(1.46)$ & $(3.17)$ & (1.89) & $(0.77)$ & $(0.24)$ & $(3.73)$ \\
\hline \multirow[t]{2}{*}{$\begin{array}{l}\text { Target shares owned by bidder } \\
\text { before M\&A }\end{array}$} & -0.0568 & -0.0678 & -0.0623 & $-0.305^{*}$ & -0.00362 & 0.00549 & -0.0134 & -0.211 & $0.526 * * *$ & $0.207^{*}$ & $2.226 * * *$ & 0.996 \\
\hline & $(-0.85)$ & $(-0.71)$ & $(-0.55)$ & $(-2.10)$ & $(-0.05)$ & $(0.06)$ & $(-0.12)$ & $(-1.44)$ & (5.09) & $(2.06)$ & $(9.38)$ & $(1.57)$ \\
\hline \multirow[t]{2}{*}{$\begin{array}{l}\text { Target shares owned by bidder } \\
\text { after M\&A }\end{array}$} & $0.253^{* * *}$ & $0.334 * * *$ & -0.149 & -0.139 & $0.222 * * *$ & $0.256^{* * *}$ & -0.105 & -0.161 & $-0.597 * * *$ & -0.0672 & $-3.032 * * *$ & -0.160 \\
\hline & $(6.43)$ & $(8.53)$ & $(-0.86)$ & $(-0.77)$ & (7.16) & $(6.03)$ & $(-0.63)$ & $(-0.92)$ & $(-4.21)$ & $(-0.79)$ & $(-9.77)$ & $(-1.15)$ \\
\hline \multirow[t]{2}{*}{ _cons } & -0.162 & -0.284 & 0.177 & 0.130 & -0.153 & -0.127 & 0.0870 & 0.124 & $0.587^{* * *}$ & 0.137 & $2.935^{* * *}$ & -0.258 \\
\hline & $(-1.36)$ & $(-1.66)$ & $(0.91)$ & $(0.54)$ & $(-1.42)$ & $(-0.72)$ & $(0.46)$ & $(0.50)$ & (3.55) & $(0.82)$ & $(9.63)$ & $(-1.13)$ \\
\hline $\mathbf{N}$ & 2559 & 1029 & 741 & 275 & 2559 & 1029 & 741 & 275 & 2559 & 1029 & 741 & 275 \\
\hline adj.R-sq & 0.263 & 0.507 & 0.119 & 0.292 & 0.27 & 0.512 & 0.142 & 0.312 & 0.384 & 0.537 & 0.765 & 0.537 \\
\hline $\begin{array}{l}t \text { statistics in parentheses } \\
{ }^{*} p<0.05,{ }^{* *} p<0.01, * * * p<0.001\end{array}$ & & & & & & & & & & & & \\
\hline
\end{tabular}


Appendix C. Regression results of M\&A premiums, idiosyncratic volatility, real option variables, and interaction terms between

idiosyncratic volatility and real option variables

\begin{tabular}{|c|c|c|c|c|c|c|c|c|c|c|c|c|}
\hline & \multicolumn{4}{|c|}{ Sales } & \multicolumn{4}{|c|}{ Assets } & \multicolumn{4}{|c|}{ Market value } \\
\hline & (1) & (2) & (3) & (4) & (5) & (6) & (7) & (8) & (9) & (10) & (11) & (12) \\
\hline $\begin{array}{l}\text { Dependent variable: M\&A } \\
\text { premiums }\end{array}$ & Full & Cash & Stock & Mix & Full & Cash & Stock & Mix & Full & Cash & Stock & Mix \\
\hline \multirow[t]{2}{*}{ Target idiosyncratic volatility } & 8.168 & 3.149 & $33.43^{* *}$ & 1.562 & 5.492 & 1.522 & $29.68^{* *}$ & -8.621 & 0.836 & -0.880 & $10.34 *$ & -8.440 \\
\hline & $(1.49)$ & $(0.48)$ & $(3.24)$ & $(0.06)$ & $(0.99)$ & $(0.23)$ & $(2.89)$ & $(-0.33)$ & $(0.16)$ & $(-0.14)$ & $(2.14)$ & $(-0.43)$ \\
\hline \multirow[t]{2}{*}{ Bidder idiosyncratic volatility } & -0.405 & $-2.500 * * *$ & -0.00294 & 3.117 & -0.634 & $-2.284 * *$ & -0.621 & 2.426 & -0.273 & $-2.251^{* * *}$ & -0.165 & 2.198 \\
\hline & $(-0.83)$ & $(-3.49)$ & $(-0.00)$ & $(1.72)$ & $(-1.40)$ & $(-3.20)$ & $(-0.99)$ & $(1.43)$ & $(-0.69)$ & $(-3.45)$ & $(-0.56)$ & $(1.82)$ \\
\hline \multirow[t]{2}{*}{ Target R\&D to market value } & 0.155 & -0.422 & 1.664 & -0.441 & -0.0187 & -0.316 & 1.059 & -0.690 & -0.00177 & -0.439 & 0.147 & -0.925 \\
\hline & $(0.38)$ & $(-0.85)$ & $(1.92)$ & $(-0.25)$ & $(-0.05)$ & $(-0.61)$ & $(1.32)$ & $(-0.40)$ & $(-0.00)$ & $(-0.86)$ & $(0.35)$ & $(-0.84)$ \\
\hline \multirow[t]{2}{*}{ Target R\&D to sales } & 0.0431 & 0.0203 & -0.0663 & 0.320 & 0.0452 & 0.0134 & -0.0227 & 0.280 & 0.0429 & 0.0185 & -0.00777 & 0.230 \\
\hline & $(1.43)$ & $(1.15)$ & $(-1.41)$ & $(1.67)$ & $(1.34)$ & $(0.77)$ & $(-0.50)$ & $(1.61)$ & $(1.30)$ & $(1.11)$ & $(-0.35)$ & $(1.84)$ \\
\hline \multirow[t]{2}{*}{ Target R\&D growth } & -0.0188 & -0.0285 & -0.0569 & 0.232 & -0.0232 & -0.0213 & -0.0478 & 0.327 & -0.00361 & -0.00867 & -0.0304 & 0.240 \\
\hline & $(-0.87)$ & $(-0.63)$ & $(-0.81)$ & $(0.76)$ & $(-1.06)$ & $(-0.48)$ & $(-0.62)$ & $(1.09)$ & $(-0.19)$ & $(-0.20)$ & $(-1.11)$ & $(1.15)$ \\
\hline \multirow[t]{2}{*}{ Target organizational flexibility } & 0.00187 & $0.203^{*}$ & 0.0691 & 0.0820 & 0.00480 & 0.148 & 0.0386 & -0.0502 & -0.00267 & $0.184^{*}$ & 0.0217 & 0.0570 \\
\hline & $(0.20)$ & $(2.51)$ & $(1.13)$ & $(0.21)$ & $(0.58)$ & $(1.76)$ & $(0.63)$ & $(-0.12)$ & $(-0.30)$ & $(2.35)$ & $(0.75)$ & $(0.23)$ \\
\hline \multirow[t]{2}{*}{$\begin{array}{l}\text { Target financial flexibility } \\
\text { (leverage) }\end{array}$} & 0.0489 & $0.138^{*}$ & $0.327^{*}$ & 0.395 & 0.180 & $0.184^{*}$ & $0.618^{* * *}$ & 0.391 & 0.0435 & $0.137^{*}$ & $0.134^{*}$ & 0.172 \\
\hline & $(0.35)$ & $(2.05)$ & $(2.46)$ & $(1.65)$ & $(1.25)$ & $(2.55)$ & $(4.57)$ & $(1.65)$ & $(0.33)$ & $(2.06)$ & $(2.15)$ & $(0.85)$ \\
\hline \multirow[t]{2}{*}{$\begin{array}{l}\text { Target financial flexibility } \\
\text { (cashflow coverage) }\end{array}$} & -0.0408 & -0.0177 & -0.0157 & 0.00695 & -0.0632 & -0.0183 & -0.0695 & -0.0445 & -0.0175 & -0.00684 & 0.0276 & 0.0779 \\
\hline & $(-1.09)$ & $(-0.42)$ & $(-0.20)$ & $(0.04)$ & $(-1.71)$ & $(-0.44)$ & $(-1.03)$ & $(-0.28)$ & $(-0.53)$ & $(-0.17)$ & $(1.21)$ & $(0.68)$ \\
\hline \multirow[t]{2}{*}{ Target sales growth } & $-0.00112 * *$ & 0.0129 & 0.0143 & -0.115 & -0.000722 & 0.00784 & 0.00702 & -0.136 & $-0.00155^{* * *}$ & 0.00220 & 0.00825 & -0.0607 \\
\hline & $(-2.77)$ & $(0.41)$ & $(0.37)$ & $(-1.11)$ & $(-1.55)$ & $(0.25)$ & $(0.17)$ & $(-1.36)$ & $(-3.34)$ & $(0.07)$ & $(0.49)$ & $(-0.91)$ \\
\hline \multirow[t]{2}{*}{ Bidder R\&D to market value } & -0.00890 & 0.00261 & -0.0344 & $0.0642^{*}$ & -0.00327 & 0.00120 & -0.0311 & 0.0497 & 0.000536 & 0.00682 & -0.00760 & 0.0441 \\
\hline & $(-0.58)$ & $(0.04)$ & $(-1.20)$ & $(2.36)$ & $(-0.21)$ & $(0.02)$ & $(-1.04)$ & $(1.68)$ & $(0.04)$ & $(0.12)$ & $(-0.71)$ & $(1.90)$ \\
\hline \multirow[t]{2}{*}{ Bidder R\&D to sales } & 0.00202 & 0.00229 & 0.135 & -1.203 & 0.0273 & 0.0162 & 0.129 & -1.366 & 0.00690 & 0.00765 & 0.0462 & -0.805 \\
\hline & $(0.04)$ & $(0.02)$ & $(0.71)$ & $(-1.20)$ & $(0.50)$ & $(0.17)$ & $(0.66)$ & $(-1.36)$ & $(0.13)$ & $(0.07)$ & $(0.50)$ & $(-0.96)$ \\
\hline \multirow[t]{2}{*}{ Bidder R\&D growth } & 0.00770 & -0.0166 & -0.0253 & 0.114 & 0.0144 & -0.0221 & -0.0245 & 0.0834 & 0.00971 & -0.0148 & -0.0164 & 0.123 \\
\hline & $(0.30)$ & $(-0.37)$ & $(-0.37)$ & $(0.88)$ & $(0.57)$ & $(-0.48)$ & $(-0.37)$ & $(0.67)$ & $(0.41)$ & $(-0.32)$ & $(-0.63)$ & (1.13) \\
\hline
\end{tabular}




\begin{tabular}{|c|c|c|c|c|c|c|c|c|c|c|c|c|}
\hline \multirow[t]{2}{*}{ Industry relatedness } & -0.0284 & 0.0166 & -0.0425 & -0.0966 & -0.0173 & 0.0181 & -0.0280 & -0.0819 & -0.0264 & 0.00721 & -0.0239 & -0.0676 \\
\hline & $(-1.55)$ & $(0.64)$ & $(-1.14)$ & $(-1.47)$ & $(-0.94)$ & $(0.71)$ & $(-0.76)$ & $(-1.27)$ & $(-1.68)$ & $(0.30)$ & $(-1.33)$ & $(-1.34)$ \\
\hline \multirow[t]{2}{*}{ Financial synergy } & 0.0000323 & -0.00187 & 0.000406 & $0.000626^{*}$ & -0.000162 & $-0.00205^{*}$ & -0.000586 & $0.000480 *$ & -0.0000572 & -0.00175 & 0.000218 & 0.000292 \\
\hline & $(0.18)$ & $(-1.94)$ & $(0.38)$ & (2.03) & $(-0.62)$ & $(-2.09)$ & $(-0.93)$ & (2.04) & $(-0.29)$ & $(-1.92)$ & $(0.48)$ & (1.32) \\
\hline \multirow[t]{2}{*}{ Relative size (sales) } & -0.00780 & $-0.0410^{*}$ & -0.00358 & -0.0254 & & & & & & & & \\
\hline & $(-1.45)$ & $(-2.23)$ & $(-0.62)$ & $(-1.52)$ & & & & & & & & \\
\hline \multirow[t]{2}{*}{ Relative size (asset) } & & & & & 0.0609 & -7.936 & 0.347 & $-10.10^{*}$ & & & & \\
\hline & & & & & $(0.12)$ & $(-1.70)$ & $(0.86)$ & $(-2.07)$ & & & & \\
\hline \multirow[t]{2}{*}{ Relative size (market value) } & & & & & & & & & $-0.00102 *$ & $-0.00144^{* *}$ & -0.0104 & 0.00430 \\
\hline & & & & & & & & & $(-1.99)$ & $(-2.91)$ & $(-1.14)$ & $(0.25)$ \\
\hline \multirow[t]{2}{*}{ Number of competing bids } & $0.222 * * *$ & $0.303^{* * *}$ & $0.142^{*}$ & 0.141 & $0.217 * * *$ & $0.301 * * *$ & $0.159 * *$ & 0.144 & $0.167 * * *$ & $0.267 * * *$ & $0.0392 *$ & 0.0755 \\
\hline & $(6.26)$ & (5.19) & (2.31) & (1.28) & $(6.20)$ & (5.24) & (2.91) & (1.35) & (5.39) & (4.87) & (2.00) & $(0.90)$ \\
\hline \multirow[t]{2}{*}{ Cash } & 0.00914 & 0 & 0 & 0 & 0.0121 & 0 & 0 & 0 & $0.0751^{* * *}$ & 0 & 0 & 0 \\
\hline & $(0.41)$ & (.) & (.) & (.) & $(0.54)$ & (.) & (.) & (.) & $(3.78)$ & (.) & (.) & (.) \\
\hline \multirow[t]{2}{*}{ Stock } & 0.0222 & 0 & 0 & 0 & $0.0368^{*}$ & 0 & 0 & 0 & $0.0891 * * *$ & 0 & 0 & 0 \\
\hline & $(1.18)$ & (.) & (.) & (.) & $(1.97)$ & (.) & (.) & (.) & $(5.30)$ & (.) & (.) & (.) \\
\hline \multirow[t]{2}{*}{ Tender offer } & $0.146 * * *$ & $0.0999 * * *$ & $0.262^{*}$ & $0.226^{*}$ & $0.134 * * *$ & $0.0971 * * *$ & 0.222 & $0.228^{*}$ & $0.0924^{* * *}$ & $0.0769 * * *$ & -0.0594 & $0.203^{* *}$ \\
\hline & (7.07) & $(5.15)$ & $(2.38)$ & $(2.21)$ & $(6.37)$ & $(4.82)$ & $(1.92)$ & $(2.32)$ & $(4.38)$ & $(3.84)$ & $(-0.60)$ & $(2.65)$ \\
\hline \multirow[t]{2}{*}{ Merger of equal } & $-0.287^{* * *}$ & 0 & $-0.306 * * *$ & -0.0957 & $-0.288 * * *$ & 0 & $-0.323 * * *$ & -0.0726 & $-0.225^{* * *}$ & 0 & -0.0470 & -0.0455 \\
\hline & $(-5.93)$ & (.) & $(-5.35)$ & $(-1.59)$ & $(-6.01)$ & (.) & $(-5.70)$ & $(-1.54)$ & $(-5.99)$ & (.) & $(-1.86)$ & $(-1.19)$ \\
\hline \multirow[t]{2}{*}{ Deal size } & $0.0580 * *$ & -0.0201 & $0.145^{* * *}$ & -0.0648 & $0.0941^{* * *}$ & 0.0369 & $0.178 * * *$ & 0.115 & $0.723 * * *$ & $0.302 * * *$ & $2.597 * * *$ & 1.285 \\
\hline & $(2.63)$ & $(-0.75)$ & $(3.47)$ & $(-1.00)$ & $(4.94)$ & $(1.26)$ & $(4.80)$ & $(1.45)$ & $(7.20)$ & $(4.98)$ & (13.74) & (1.94) \\
\hline \multirow[t]{2}{*}{ Hostile acquisition } & 0.000951 & -0.0143 & -0.221 & 0.0868 & -0.0133 & -0.0400 & -0.239 & 0.157 & -0.0103 & -0.0369 & -0.0221 & 0.00393 \\
\hline & $(0.02)$ & $(-0.16)$ & $(-1.78)$ & $(0.77)$ & $(-0.23)$ & $(-0.44)$ & $(-1.91)$ & (1.39) & $(-0.23)$ & $(-0.46)$ & $(-0.33)$ & $(0.04)$ \\
\hline \multirow[t]{2}{*}{ Number of day to effective } & 0.00000066 & -0.000033 & 0.000160 & 0.000514 & 0.00000385 & -0.0000311 & $0.00029 *$ & 0.000625 & 0.0000614 & -0.0000030 & $0.000212^{*}$ & 0.000226 \\
\hline & $(0.02)$ & $(-1.22)$ & $(1.31)$ & $(1.35)$ & $(0.13)$ & $(-1.13)$ & (2.27) & $(1.63)$ & (1.64) & $(-0.11)$ & $(2.16)$ & $(0.91)$ \\
\hline \multirow[t]{2}{*}{ Target resistance to takeover } & 0.0667 & 0.133 & 0.0556 & $-0.456 *$ & 0.0776 & 0.149 & 0.0304 & $-0.530 * *$ & 0.0682 & 0.150 & -0.0209 & $-0.375^{* *}$ \\
\hline & $(0.91)$ & $(1.71)$ & $(0.48)$ & $(-2.58)$ & $(1.08)$ & $(1.90)$ & $(0.27)$ & $(-3.02)$ & $(1.16)$ & $(1.95)$ & $(-0.29)$ & $(-2.69)$ \\
\hline \multirow[t]{2}{*}{ Target business risk } & -4.667 & 4.436 & $-25.57 * *$ & 5.345 & -1.936 & 5.543 & $-21.16^{*}$ & 12.14 & 1.324 & 7.058 & -7.304 & 12.21 \\
\hline & $(-1.01)$ & $(0.69)$ & $(-2.70)$ & $(0.26)$ & $(-0.41)$ & $(0.88)$ & $(-2.22)$ & $(0.57)$ & $(0.32)$ & $(1.17)$ & $(-1.71)$ & $(0.79)$ \\
\hline \multirow[t]{2}{*}{ Target firm size (sales) } & $-0.0664 * *$ & 0.0157 & $-0.154^{* * *}$ & 0.0354 & & & & & & & & \\
\hline & $(-2.97)$ & $(0.67)$ & $(-4.00)$ & $(0.64)$ & & & & & & & & \\
\hline \multirow[t]{2}{*}{ Target firm size (assets) } & & & & & $-0.120 * * *$ & $-0.0759 *$ & $-0.211 * * *$ & $-0.200^{*}$ & & & & \\
\hline & & & & & $(-6.04)$ & $(-2.46)$ & $(-5.74)$ & $(-2.23)$ & & & & \\
\hline
\end{tabular}




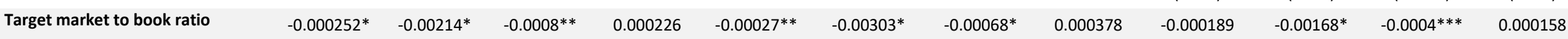

\begin{tabular}{|c|c|c|c|c|c|c|c|c|c|c|c|c|}
\hline & $(-2.51)$ & $(-2.22)$ & $(-2.81)$ & $(1.04)$ & $(-2.76)$ & $(-2.42)$ & $(-2.40)$ & $(1.52)$ & $(-1.94)$ & $(-2.23)$ & $(-3.78)$ & $(1.09)$ \\
\hline Target ROA & $0.000824 *$ & 0.000054 & 0.00163 & 0.0000323 & $0.00107^{* *}$ & -0.0000454 & $0.0034^{* *}$ & -0.00266 & 0.000528 & 0.000170 & -0.000488 & -0.00159 \\
\hline
\end{tabular}

\begin{tabular}{|c|c|c|c|c|c|c|c|c|c|c|c|c|}
\hline Target ROA & $0.000824^{*}$ & 0.000054 & 0.00163 & 0.0000323 & $0.00107^{* *}$ & -0.0000454 & $0.0034^{* *}$ & -0.00266 & 0.000528 & 0.000170 & -0.000488 & -0.00159 \\
\hline & (2.08) & $(0.11)$ & (1.63) & $(0.01)$ & (2.64) & $(-0.09)$ & (3.10) & $(-0.52)$ & $(1.30)$ & $(0.40)$ & $(-1.03)$ & $(-0.45)$ \\
\hline
\end{tabular}

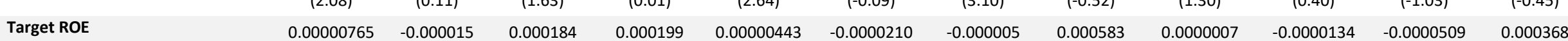

\begin{tabular}{|c|c|c|c|c|c|c|c|c|c|c|c|c|}
\hline & $(0.26)$ & $(-0.74)$ & $(0.94)$ & $(0.34)$ & $(0.14)$ & $(-1.77)$ & $(-0.02)$ & $(0.96)$ & $(0.03)$ & $(-0.68)$ & $(-0.65)$ & $(0.93)$ \\
\hline Target operating cashflow & -0.000521 & -0.00960 & 0.0000256 & -0.0205 & -0.000286 & -0.00742 & $0.0007^{* * *}$ & $-0.0261 *$ & -0.000268 & -0.00720 & $0.00033^{* * *}$ & $-0.0182 *$ \\
\hline
\end{tabular}

\begin{tabular}{|c|c|c|c|c|c|c|c|c|c|c|c|c|}
\hline Target operating cashflow & -0.000521 & -0.00960 & 0.0000256 & -0.0205 & -0.000286 & -0.00742 & $0.0007^{* * *}$ & $-0.0261^{*}$ & -0.000268 & -0.00720 & $0.00033^{* * *}$ & $-0.0182 *$ \\
\hline & $(-0.42)$ & $(-1.37)$ & $(0.12)$ & $(-1.79)$ & $(-0.22)$ & $(-1.09)$ & $(5.33)$ & $(-2.40)$ & $(-0.23)$ & $(-1.14)$ & $(5.00)$ & $(-2.41)$ \\
\hline
\end{tabular}

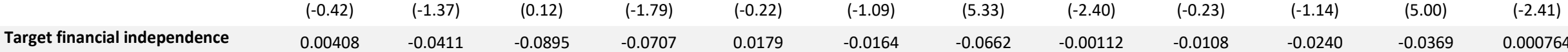

Target debt to equity

$\begin{array}{lllll}(-1.07) & (-0.48) & (0.34) & (-0.30) & (-0.78)\end{array}$

$(-0.01) \quad(-0.23)$

$(-0.45)$

$(-1.07) \quad(0.01)$

Target debt to equity

0.000

$\begin{array}{llll}(0.01) & (2.03) & (-0.89) & (-2.69)\end{array}$

$(-2.69)$

$0.000358 \quad 0.00497^{* *} \quad 0.00106$

$\begin{array}{ll}-0.000968 & 0.000114\end{array}$

0.00304

0.000269

$-0.00125$

Public bidder

$$
0.113
$$

before M\&A

$\begin{array}{lll}(1.68) & 0.0937 & 0.113\end{array}$

oidder

after M\&A

Target idiosyncratic volatility

Target R\&D to market value

$-0.0609$

(0.66) (1.55)

0.216

(1.10)

(3.20)

$(0.66$

$(-0.35)$

$(0.42)$

$(2.06)$

$(0.43)$

$(-0.63)$

Target idiosyncratic volatility *
Target R\&D to market value
Target idiosyncratic volatility *

Target R\&D to sales

$-0.057$

0.0485

(1.81)

$(2.14$

$(0.59)$

$(1.52)$

(2.97)

(1.93)

0.0932

(0.78) (0.30)

$(-0.89)$

$(-0.59) \quad(-0.43)$

$(-2.17)$

$-0.00455$

0.00438

$-0.207$

$0.528 * * *$

$\begin{array}{llll}(-0.07) & (0.09) & (0.04) & (-1.41)\end{array}$

(5.03)

(2.18)

$(-0.91)$

0.220

$0.274^{* * *}$

$-0.123$

$-0.198$

$-0.593^{* * *}$

$-0.0614$

$(-1.02) \quad(-4.18)$

(-0.73)

23.99*

$33.13^{* *}$

11.97

41.43

21.34*

$34.08^{* *}$

(0.75)

(2.38)

(2.71)

(0.74)

(0.94)

(2.30)

(2.91)

0.168

$-11.76$

$-0.785$

$-0.344$

$(-1.68)$

(-1.29)

$(-1.10)$

Target idiosyncratic volatility

Target R\&D growth

$(-1.42)$

$(-1.11)$

(1.06)

$(-1.44)$

$(-1.33)$

$(-0.76)$

$0.24)$

$-6.637$

0.134

0.00144

(0.63)

Target idiosyncratic volatility *

(0.91) (0.39)

Target organizational flexibility

Target idiosyncratic volatility *

Target financial flexibility

$-0.264 \quad-4.164 \quad-1.66$

$(-0.4$

$(-1.82)$

$(-1.50)$

(1.23)

(0.17)

(0.63)

$(-0.82)$

(0.38)

0.0014

$2.222^{* * *}$

(leverage)

$-2.589$

$(-0.36)$

(0.69)

(-0.86)

1.635

$-0.108$

(0.15)

$(-0.19)$

$-3.962$

$(-1.83)$

1.923

$(-2.94)$

(0.15)

(0.29)

7.491

(1.21)

$(-2.40)$ 


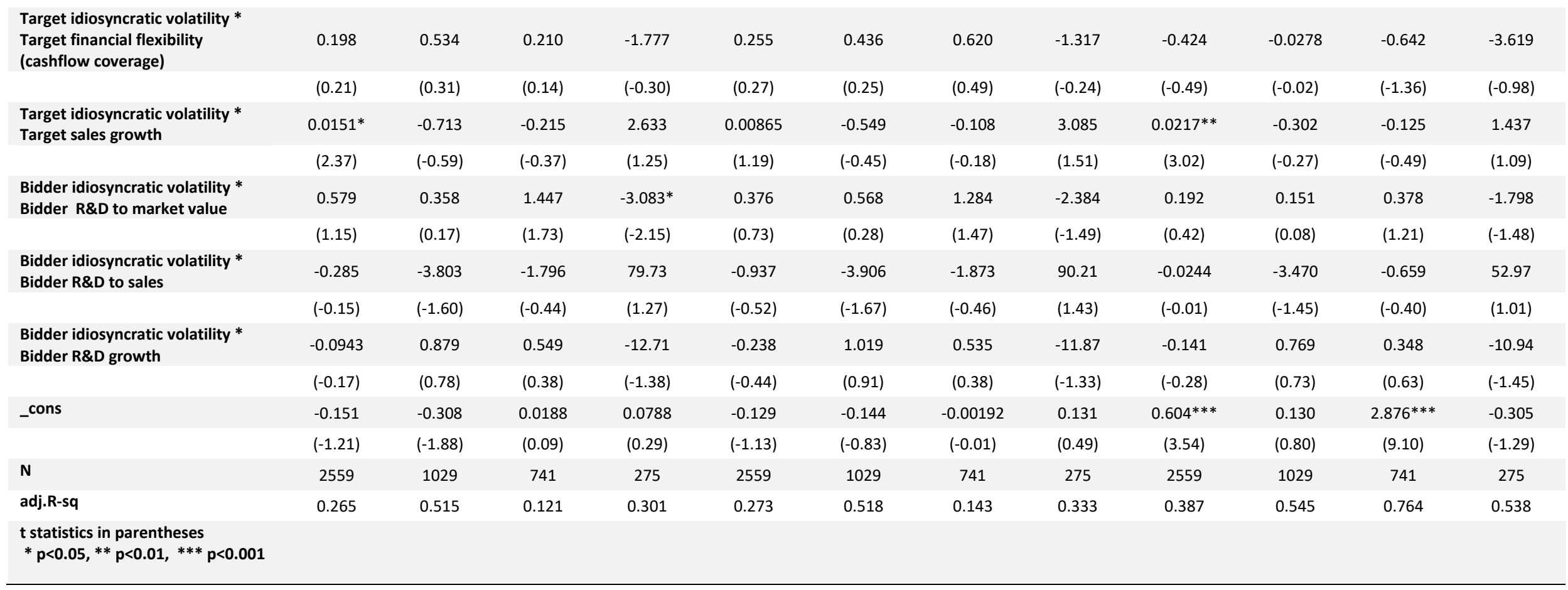


Appendix D. Regression results of M\&A premiums, total volatility, and real option variables

\begin{tabular}{|c|c|c|c|c|c|c|c|c|c|c|c|c|}
\hline & \multicolumn{4}{|c|}{ Sales } & \multicolumn{4}{|c|}{ Assets } & \multicolumn{4}{|c|}{ Market value } \\
\hline & (1) & (2) & (3) & (4) & (5) & (6) & (7) & (8) & (9) & (10) & (11) & (12) \\
\hline $\begin{array}{l}\text { Dependent variable: M\&A } \\
\text { premiums }\end{array}$ & Full & Cash & Stock & Mix & Full & Cash & Stock & Mix & Full & Cash & Stock & Mix \\
\hline \multirow[t]{2}{*}{ Target total volatility } & $5.570^{*}$ & $8.101^{* * *}$ & 2.739 & -4.239 & 4.269 & $7.433 * * *$ & -0.216 & -3.032 & 2.888 & $7.150 * * *$ & -0.856 & 1.839 \\
\hline & $(2.03)$ & $(4.57)$ & $(1.71)$ & $(-0.89)$ & $(1.55)$ & $(4.07)$ & $(-0.14)$ & $(-0.76)$ & $(1.18)$ & $(4.39)$ & $(-1.08)$ & $(0.59)$ \\
\hline \multirow[t]{2}{*}{ Bidder total volatility } & -0.434 & $-2.409 * * *$ & -0.211 & 2.864 & -0.638 & $-2.195^{* *}$ & -0.663 & 2.597 & -0.233 & $-2.183^{* * *}$ & -0.185 & 1.998 \\
\hline & $(-0.97)$ & $(-3.61)$ & $(-0.34)$ & $(1.85)$ & $(-1.48)$ & $(-3.24)$ & $(-1.09)$ & $(1.66)$ & $(-0.64)$ & $(-3.61)$ & $(-0.74)$ & (1.74) \\
\hline \multirow[t]{2}{*}{ Target R\&D to market value } & $1.107^{* * *}$ & $1.207 * * *$ & $1.731 * * *$ & 0.504 & $1.090 * * *$ & $1.243 * * *$ & $1.573 * * *$ & 0.455 & $0.994 * * *$ & $1.176^{* * *}$ & 0.264 & -0.108 \\
\hline & $(4.97)$ & $(3.54)$ & $(3.66)$ & $(0.72)$ & $(4.83)$ & $(3.67)$ & $(3.50)$ & $(0.68)$ & $(4.80)$ & $(3.61)$ & $(1.35)$ & $(-0.20)$ \\
\hline \multirow[t]{2}{*}{ Target R\&D to sales } & 0.000656 & 0.000105 & $-0.0163 *$ & 0.0826 & 0.000905 & -0.000121 & -0.0101 & 0.0156 & 0.000758 & 0.0000430 & -0.00522 & 0.0360 \\
\hline & $(0.80)$ & $(0.18)$ & $(-2.42)$ & $(1.38)$ & $(0.92)$ & $(-0.21)$ & $(-1.47)$ & $(0.30)$ & $(0.87)$ & $(0.08)$ & $(-1.95)$ & $(0.94)$ \\
\hline \multirow[t]{2}{*}{ Target R\&D growth } & 0.00145 & -0.0150 & -0.0107 & 0.0407 & 0.00258 & -0.0169 & 0.00128 & 0.0569 & 0.00667 & -0.0114 & 0.000272 & 0.0328 \\
\hline & $(0.11)$ & $(-0.72)$ & $(-0.40)$ & $(0.40)$ & $(0.20)$ & $(-0.83)$ & $(0.05)$ & $(0.60)$ & $(0.59)$ & $(-0.61)$ & $(0.03)$ & $(0.43)$ \\
\hline \multirow[t]{2}{*}{ Target organizational flexibility } & -0.00421 & 0.00710 & -0.00864 & 0.0497 & -0.00413 & -0.0189 & -0.00676 & 0.0185 & -0.00501 & 0.00524 & -0.00350 & 0.0675 \\
\hline & $(-0.86)$ & $(0.17)$ & $(-0.37)$ & $(0.38)$ & $(-0.81)$ & $(-0.46)$ & $(-0.31)$ & $(0.14)$ & $(-1.27)$ & $(0.14)$ & $(-0.39)$ & $(0.93)$ \\
\hline \multirow[t]{2}{*}{ Target financial flexibility (leverage) } & 0.0656 & 0.0913 & 0.227 & 0.350 & 0.201 & 0.147 & $0.551 * * *$ & $0.359 *$ & 0.0538 & 0.0849 & 0.0921 & 0.0439 \\
\hline & $(0.46)$ & $(1.13)$ & $(1.94)$ & $(1.94)$ & $(1.38)$ & $(1.74)$ & $(4.31)$ & $(2.00)$ & $(0.40)$ & $(1.09)$ & $(1.75)$ & $(0.27)$ \\
\hline \multirow[t]{2}{*}{$\begin{array}{l}\text { Target financial flexibility (cashflow } \\
\text { coverage) }\end{array}$} & -0.0375 & 0.00136 & -0.0104 & -0.0269 & $-0.0573 * *$ & -0.00327 & -0.0484 & -0.0626 & $-0.0395^{*}$ & -0.00633 & -0.00365 & -0.00853 \\
\hline & $(-1.90)$ & $(0.04)$ & $(-0.35)$ & $(-0.29)$ & $(-2.79)$ & $(-0.11)$ & $(-1.70)$ & $(-0.78)$ & $(-2.21)$ & $(-0.22)$ & $(-0.44)$ & $(-0.15)$ \\
\hline \multirow[t]{2}{*}{ Target sales growth } & $-0.00015^{* *}$ & -0.00565 & -0.000039 & 0.00348 & $-0.000158 * * *$ & -0.00673 & -0.0000996 & -0.00163 & $-0.000166 * *$ & -0.00548 & -0.0000423 & 0.00216 \\
\hline & $(-3.23)$ & $(-1.24)$ & $(-0.47)$ & $(0.18)$ & $(-4.31)$ & $(-1.62)$ & $(-1.20)$ & $(-0.08)$ & $(-2.96)$ & $(-1.33)$ & $(-1.28)$ & $(0.17)$ \\
\hline \multirow[t]{2}{*}{ Bidder R\&D to market value } & 0.00355 & 0.0107 & 0.00972 & -0.00258 & 0.00349 & $0.0152 *$ & 0.00849 & $\begin{array}{c}0.00023 \\
1\end{array}$ & 0.00281 & 0.00953 & 0.00394 & 0.00747 \\
\hline & $(0.54)$ & $(1.51)$ & $(1.26)$ & $(-0.23)$ & $(0.53)$ & $(2.05)$ & $(1.08)$ & $(0.02)$ & $(0.51)$ & $(1.48)$ & $(1.72)$ & $(0.89)$ \\
\hline \multirow[t]{2}{*}{ Bidder R\&D to sales } & -0.00826 & -0.101 & 0.0793 & 0.0682 & 0.00128 & -0.0894 & 0.0681 & 0.0742 & 0.00588 & -0.0858 & 0.0222 & 0.0409 \\
\hline & $(-0.24)$ & $(-1.48)$ & $(0.93)$ & $(1.58)$ & $(0.04)$ & $(-1.38)$ & $(0.79)$ & (1.69) & $(0.20)$ & $(-1.22)$ & $(0.68)$ & $(1.24)$ \\
\hline \multirow[t]{2}{*}{ Bidder R\&D growth } & 0.00414 & 0.00322 & 0.00170 & -0.0447 & 0.00410 & 0.00233 & 0.00167 & -0.0570 & 0.00371 & 0.00161 & 0.000375 & -0.0258 \\
\hline & $(1.38)$ & $(0.10)$ & $(0.88)$ & $(-0.89)$ & $(1.25)$ & $(0.07)$ & $(0.88)$ & $(-1.26)$ & $(1.38)$ & $(0.05)$ & $(0.78)$ & $(-0.73)$ \\
\hline \multirow[t]{2}{*}{ Industry relatedness } & -0.0305 & 0.0130 & -0.0412 & -0.0991 & -0.0195 & 0.0160 & -0.0261 & -0.0888 & -0.0286 & 0.00438 & -0.0243 & -0.0693 \\
\hline & $(-1.67)$ & $(0.51)$ & $(-1.11)$ & $(-1.59)$ & $(-1.05)$ & $(0.63)$ & $(-0.71)$ & $(-1.43)$ & $(-1.83)$ & $(0.18)$ & $(-1.36)$ & $(-1.42)$ \\
\hline
\end{tabular}




\begin{tabular}{|c|c|c|c|c|c|c|c|c|c|c|c|c|}
\hline Financial synergy & 0.0000339 & -0.00174 & 0.000431 & $\begin{array}{c}0.000605 \\
*\end{array}$ & -0.000171 & $-0.00202 *$ & -0.000644 & $\begin{array}{c}0.00044 \\
5\end{array}$ & -0.0000615 & -0.00169 & 0.000180 & 0.000268 \\
\hline & $(0.19)$ & $(-1.80)$ & $(0.43)$ & $(2.05)$ & $(-0.64)$ & $(-2.05)$ & $(-1.04)$ & $(1.97)$ & $(-0.30)$ & $(-1.87)$ & $(0.43)$ & $(1.23)$ \\
\hline \multirow[t]{2}{*}{ Relative size (sales) } & -0.00784 & $-0.0403^{*}$ & -0.00342 & -0.0223 & & & & & & & & \\
\hline & $(-1.36)$ & $(-2.17)$ & $(-0.54)$ & $(-1.45)$ & & & & & & & & \\
\hline \multirow[t]{2}{*}{ Relative size (asset) } & & & & & 0.0258 & -8.419 & 0.414 & $-7.865 *$ & & & & \\
\hline & & & & & $(0.05)$ & $(-1.81)$ & $(1.06)$ & $(-2.24)$ & & & & \\
\hline \multirow[t]{2}{*}{ Relative size (market value) } & & & & & & & & & $-0.00105^{*}$ & $-0.0015^{* * *}$ & -0.00742 & 0.00739 \\
\hline & & & & & & & & & $(-2.21)$ & $(-3.98)$ & $(-1.11)$ & $(0.62)$ \\
\hline \multirow[t]{2}{*}{ Number of competing bids } & $0.223^{* * *}$ & $0.299 * * *$ & 0.118 & 0.154 & $0.216^{* * *}$ & $0.296^{* * *}$ & $0.138^{*}$ & 0.153 & $0.165^{* * *}$ & $0.259 * * *$ & 0.0316 & 0.0796 \\
\hline & $(6.33)$ & $(5.09)$ & $(1.87)$ & $(1.55)$ & $(6.21)$ & $(5.13)$ & $(2.40)$ & $(1.59)$ & $(5.34)$ & $(4.71)$ & $(1.59)$ & $(1.03)$ \\
\hline \multirow[t]{2}{*}{ Cash } & 0.00125 & 0 & 0 & 0 & 0.00387 & 0 & 0 & 0 & $0.0702^{* * *}$ & 0 & 0 & 0 \\
\hline & $(0.06)$ & (.) & (.) & (.) & $(0.17)$ & (.) & (.) & (.) & $(3.52)$ & (.) & (.) & (.) \\
\hline \multirow[t]{2}{*}{ Stock } & 0.0215 & 0 & 0 & 0 & 0.0352 & 0 & 0 & 0 & $0.0882^{* * *}$ & 0 & 0 & 0 \\
\hline & $(1.13)$ & (.) & (.) & (.) & $(1.88)$ & (.) & (.) & (.) & $(5.24)$ & (.) & (.) & (.) \\
\hline \multirow[t]{2}{*}{ Tender offer } & $0.149 * * *$ & $0.105^{* * *}$ & 0.193 & $0.224^{*}$ & $0.136 * * *$ & $0.101^{* * *}$ & 0.192 & $0.230^{*}$ & $0.0941 * * *$ & $0.0808^{* * *}$ & -0.0692 & $0.199 * *$ \\
\hline & (7.26) & $(5.56)$ & $(1.92)$ & $(2.30)$ & $(6.50)$ & $(5.08)$ & $(1.85)$ & $(2.40)$ & $(4.46)$ & (4.09) & $(-0.76)$ & $(2.81)$ \\
\hline \multirow[t]{2}{*}{ Merger of equal } & $-0.287^{* * *}$ & 0 & $-0.305^{* * *}$ & -0.0828 & $-0.290 * * *$ & 0 & $-0.325^{* * *}$ & -0.0602 & $-0.226 * * *$ & 0 & -0.0467 & -0.0283 \\
\hline & $(-5.72)$ & (.) & $(-5.49)$ & $(-1.58)$ & $(-5.75)$ & (.) & $(-5.81)$ & $(-1.36)$ & $(-5.74)$ & (.) & $(-1.85)$ & $(-0.67)$ \\
\hline \multirow[t]{2}{*}{ Deal size } & $0.0517^{*}$ & -0.0185 & $0.123^{* *}$ & -0.114 & $0.0861^{* * *}$ & 0.0424 & $0.165^{* * *}$ & 0.0738 & $0.721 * * *$ & $0.302^{* * *}$ & $2.605^{* * *}$ & 1.320 \\
\hline & $(2.29)$ & $(-0.70)$ & $(2.96)$ & $(-1.81)$ & $(4.52)$ & $(1.45)$ & $(4.43)$ & $(0.97)$ & (7.19) & $(4.96)$ & (13.97) & $(1.96)$ \\
\hline \multirow[t]{2}{*}{ Hostile acquisition } & -0.00488 & -0.0175 & -0.155 & 0.0980 & -0.0215 & -0.0449 & -0.209 & 0.169 & -0.0179 & -0.0418 & -0.00857 & 0.0190 \\
\hline & $(-0.09)$ & $(-0.20)$ & $(-1.36)$ & $(0.93)$ & $(-0.38)$ & $(-0.52)$ & $(-1.74)$ & $(1.61)$ & $(-0.40)$ & $(-0.55)$ & $(-0.13)$ & $(0.23)$ \\
\hline \multirow[t]{2}{*}{ Number of day to effective } & 0.0000039 & -0.000023 & 0.000098 & 0.000555 & 0.00000787 & -0.0000222 & $0.000254^{*}$ & 0.00067 & 0.0000640 & 0.0000046 & $0.000204 *$ & 0.00028 \\
\hline & $(0.13)$ & $(-0.87)$ & $(0.79)$ & $(1.52)$ & $(0.27)$ & $(-0.83)$ & $(2.02)$ & $(1.80)$ & $(1.64)$ & $(0.17)$ & $(2.05)$ & $(1.20)$ \\
\hline \multirow[t]{2}{*}{ Target resistance to takeover } & 0.0581 & 0.108 & 0.0710 & $-0.452 * *$ & 0.0692 & 0.128 & 0.0404 & $-0.54 * * *$ & 0.0626 & 0.128 & -0.0289 & $-0.377^{* *}$ \\
\hline & $(0.81)$ & $(1.48)$ & $(0.66)$ & $(-2.70)$ & $(0.98)$ & $(1.71)$ & $(0.38)$ & $(-3.34)$ & $(1.10)$ & $(1.77)$ & $(-0.42)$ & $(-2.95)$ \\
\hline \multirow[t]{2}{*}{ Target business risk } & -2.269 & -1.530 & 1.213 & 8.821 & -0.616 & -1.058 & $5.748^{*}$ & 6.731 & -0.448 & -1.674 & $2.674^{*}$ & -0.654 \\
\hline & $(-0.48)$ & $(-0.64)$ & $(0.41)$ & $(1.26)$ & $(-0.13)$ & $(-0.45)$ & $(1.97)$ & $(1.11)$ & $(-0.10)$ & $(-0.74)$ & $(2.01)$ & $(-0.13)$ \\
\hline \multirow[t]{2}{*}{ Target firm size (sales) } & $-0.0722^{* *}$ & 0.00660 & $-0.150 * * *$ & 0.0663 & & & & & & & & \\
\hline & $(-2.99)$ & $(0.28)$ & $(-3.90)$ & $(1.21)$ & & & & & & & & \\
\hline \multirow[t]{2}{*}{ Target firm size (assets) } & & & & & $-0.120 * * *$ & $-0.0888 * *$ & $-0.212 * * *$ & $-0.168 *$ & & & & \\
\hline & & & & & $(-5.98)$ & $(-2.86)$ & $(-5.92)$ & $(-2.00)$ & & & & \\
\hline Target firm size (market value) & & & & & & & & & $-0.735^{* * *}$ & $-0.329 * * *$ & $-2.611^{* * *}$ & $-1.339 *$ \\
\hline
\end{tabular}




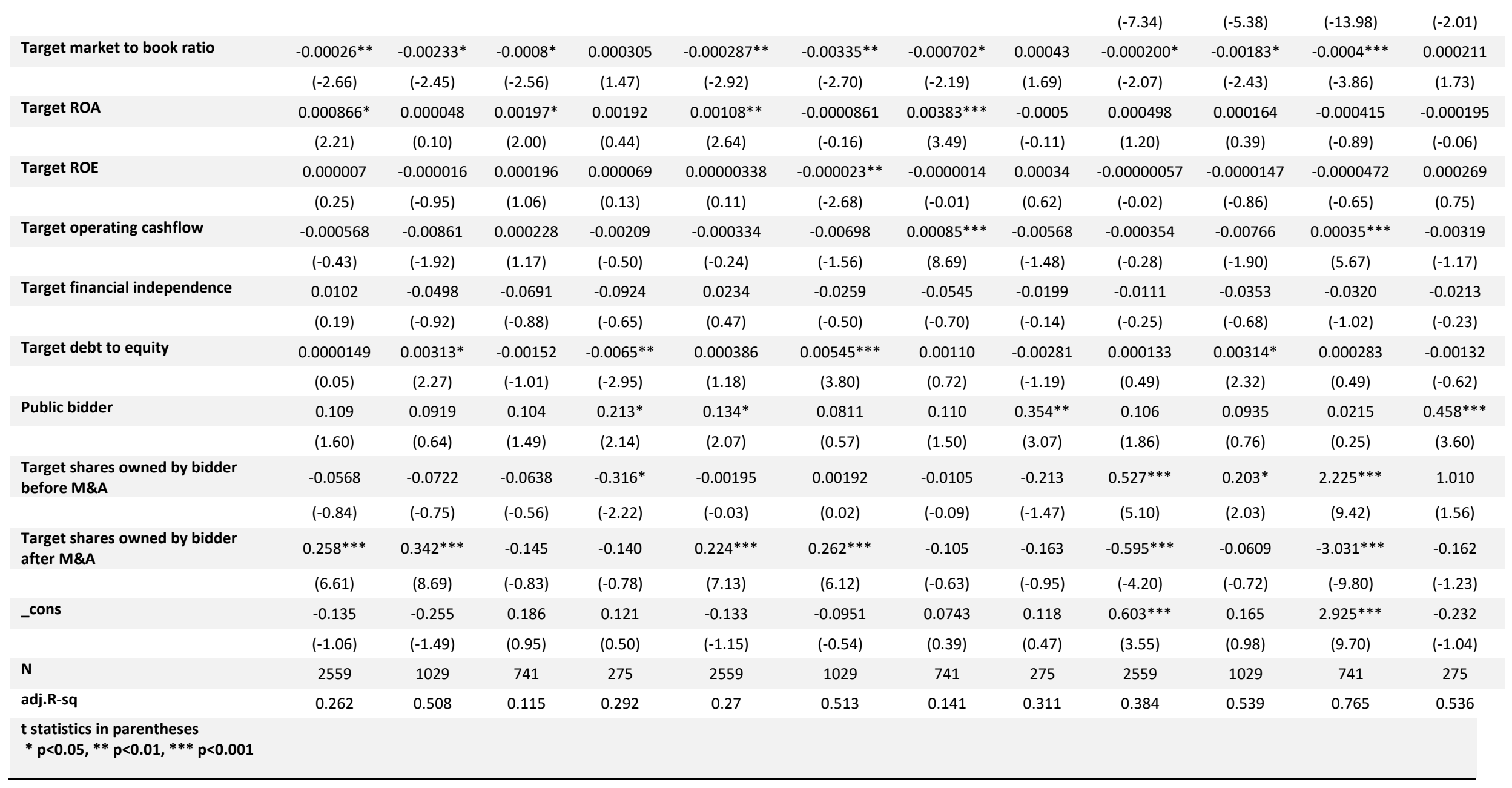


Appendix E. Regression results of M\&A premiums, total volatility, real option variables, and interaction terms between total volatility and real option variables

\begin{tabular}{|c|c|c|c|c|c|c|c|c|c|c|c|c|}
\hline & \multicolumn{4}{|c|}{ Sales } & \multicolumn{4}{|c|}{ Assets } & \multicolumn{4}{|c|}{ Market value } \\
\hline & (1) & (2) & (3) & (4) & (5) & (6) & (7) & (8) & (9) & (10) & (11) & (12) \\
\hline $\begin{array}{l}\text { Dependent variable: M\&A } \\
\text { premiums }\end{array}$ & Full & Cash & Stock & Mix & Full & Cash & Stock & Mix & Full & Cash & Stock & Mix \\
\hline \multirow[t]{2}{*}{ Target total volatility } & $5.505^{*}$ & $7.778^{* * *}$ & 4.841 & -5.621 & 4.126 & $7.056 * * *$ & $5.718^{*}$ & -4.593 & 2.817 & $6.750 * * *$ & 1.991 & 0.602 \\
\hline & $(2.01)$ & (3.94) & $(1.93)$ & $(-1.10)$ & $(1.50)$ & (3.51) & $(2.37)$ & $(-1.08)$ & $(1.16)$ & $(3.72)$ & $(1.86)$ & $(0.17)$ \\
\hline Bidder total volatility & $(-0.84)$ & $(-3.04)$ & $(-0.38)$ & $(1.84)$ & $(-1.26)$ & $(-2.75)$ & $(-1.14)$ & $(1.71)$ & $(-0.51)$ & $(-3.00)$ & $(-0.87)$ & $(1.89)$ \\
\hline \multirow[t]{2}{*}{ Target R\&D to market value } & 0.110 & -0.654 & $2.036^{*}$ & -0.713 & -0.0873 & -0.545 & 1.423 & -0.874 & -0.0365 & -0.649 & 0.200 & -1.207 \\
\hline & $(0.24)$ & $(-1.15)$ & (2.43) & $(-0.39)$ & $(-0.19)$ & $(-0.93)$ & $(1.80)$ & $(-0.51)$ & $(-0.09)$ & $(-1.13)$ & $(0.51)$ & $(-1.03)$ \\
\hline \multirow[t]{2}{*}{ Target R\&D to sales } & 0.0367 & 0.0165 & -0.0973 & 0.449 & 0.0372 & 0.0105 & -0.0352 & $0.430^{*}$ & 0.0387 & 0.0160 & -0.0111 & $0.332 *$ \\
\hline & $(1.22)$ & $(0.96)$ & $(-1.65)$ & $(1.90)$ & $(1.12)$ & $(0.62)$ & $(-0.61)$ & $(1.98)$ & (1.19) & $(1.00)$ & $(-0.42)$ & $(2.12)$ \\
\hline Target R\&D growth & -0.0189 & -0.00965 & -0.0543 & 0.295 & -0.0251 & -0.00403 & -0.0476 & 0.401 & -0.00446 & 0.00854 & -0.0257 & 0.235 \\
\hline \multirow[t]{2}{*}{ Target organizational flexibility } & 0.00205 & $0.205^{*}$ & 0.0915 & 0.219 & 0.00503 & 0.147 & 0.0513 & 0.0367 & -0.00239 & $0.188^{*}$ & 0.0258 & 0.169 \\
\hline & $(0.22)$ & $(2.39)$ & $(1.51)$ & $(0.50)$ & $(0.61)$ & $(1.66)$ & $(0.84)$ & $(0.08)$ & $(-0.27)$ & $(2.29)$ & $(0.93)$ & $(0.57)$ \\
\hline \multirow[t]{2}{*}{ Target financial flexibility (leverage) } & 0.0289 & 0.109 & $0.270^{*}$ & 0.432 & 0.162 & $0.153^{*}$ & $0.567 * * *$ & 0.383 & 0.0249 & 0.104 & 0.108 & 0.144 \\
\hline & $(0.20)$ & $(1.58)$ & $(1.98)$ & $(1.66)$ & $(1.08)$ & $(2.03)$ & $(4.06)$ & $(1.53)$ & $(0.18)$ & $(1.55)$ & $(1.79)$ & $(0.66)$ \\
\hline \multirow[t]{2}{*}{$\begin{array}{l}\text { Target financial flexibility (cashflow } \\
\text { coverage) }\end{array}$} & -0.0502 & -0.0121 & -0.0352 & -0.0706 & $-0.0770^{*}$ & -0.0127 & -0.0896 & -0.134 & -0.0230 & 0.00161 & 0.0178 & 0.0205 \\
\hline & $(-1.37)$ & $(-0.29)$ & $(-0.46)$ & $(-0.39)$ & $(-2.14)$ & $(-0.31)$ & $(-1.37)$ & $(-0.81)$ & $(-0.71)$ & $(0.04)$ & $(0.80)$ & $(0.18)$ \\
\hline \multirow[t]{2}{*}{ Target sales growth } & $-0.00106 * *$ & 0.0278 & 0.0112 & -0.138 & -0.000658 & 0.0248 & 0.00439 & -0.161 & $-0.0015^{* * *}$ & 0.0101 & 0.00672 & -0.0721 \\
\hline & $(-2.73)$ & $(0.50)$ & $(0.30)$ & $(-1.21)$ & $(-1.46)$ & $(0.45)$ & $(0.11)$ & $(-1.48)$ & $(-3.32)$ & $(0.19)$ & $(0.40)$ & $(-0.96)$ \\
\hline \multirow[t]{2}{*}{ Bidder R\&D to market value } & 0.0000199 & -0.00658 & -0.00735 & 0.0440 & 0.00267 & -0.00492 & -0.0162 & 0.0335 & 0.00443 & 0.00505 & -0.00653 & 0.0295 \\
\hline & $(0.00)$ & $(-0.08)$ & $(-0.26)$ & $(1.44)$ & $(0.17)$ & $(-0.06)$ & $(-0.61)$ & $(1.08)$ & $(0.31)$ & $(0.07)$ & $(-0.64)$ & $(1.41)$ \\
\hline \multirow[t]{2}{*}{ Bidder R\&D to sales } & 0.0168 & 0.0152 & 0.187 & -0.822 & 0.0427 & 0.0278 & 0.187 & -1.015 & 0.0194 & 0.0154 & 0.0610 & -0.438 \\
\hline & $(0.30)$ & $(0.16)$ & $(0.96)$ & $(-0.87)$ & $(0.78)$ & $(0.31)$ & $(0.96)$ & $(-1.07)$ & $(0.38)$ & $(0.15)$ & $(0.66)$ & $(-0.58)$ \\
\hline Bidder R\&D growth & 0.0156 & 0.0119 & -0.0184 & -0.0370 & 0.0229 & 0.00730 & -0.0158 & -0.0307 & 0.0161 & 0.0131 & -0.00820 & -0.00007 \\
\hline
\end{tabular}




\begin{tabular}{|c|c|c|c|c|c|c|c|c|c|c|c|c|}
\hline \multirow[t]{2}{*}{ Industry relatedness } & -0.0279 & 0.0171 & -0.0406 & -0.0835 & -0.0163 & 0.0194 & -0.0273 & -0.0713 & -0.0258 & 0.00795 & -0.0236 & -0.0604 \\
\hline & $(-1.52)$ & $(0.67)$ & $(-1.08)$ & $(-1.46)$ & $(-0.88)$ & $(0.77)$ & $(-0.74)$ & $(-1.27)$ & $(-1.64)$ & $(0.34)$ & $(-1.31)$ & $(-1.38)$ \\
\hline \multirow[t]{2}{*}{ Financial synergy } & 0.0000433 & -0.00179 & 0.000408 & $0.000627 *$ & -0.000167 & $-0.00201 *$ & -0.000643 & $0.00047 *$ & -0.0000547 & -0.00173 & 0.000183 & 0.000295 \\
\hline & $(0.25)$ & $(-1.83)$ & $(0.42)$ & $(2.01)$ & $(-0.64)$ & $(-2.01)$ & $(-1.02)$ & $(2.02)$ & $(-0.28)$ & $(-1.87)$ & $(0.43)$ & $(1.30)$ \\
\hline \multirow[t]{2}{*}{ Relative size (sales) } & -0.00780 & $-0.0410 *$ & -0.00422 & -0.0233 & & & & & & & & \\
\hline & $(-1.36)$ & $(-2.21)$ & $(-0.65)$ & $(-1.45)$ & & & & & & & & \\
\hline \multirow[t]{2}{*}{ Relative size (asset) } & & & & & 0.0767 & -8.209 & 0.464 & $-10.32 *$ & & & & \\
\hline & & & & & $(0.15)$ & $(-1.77)$ & $(1.26)$ & $(-2.46)$ & & & & \\
\hline \multirow[t]{2}{*}{ Relative size (market value) } & & & & & & & & & -0.00100 & $-0.00142 * *$ & -0.0106 & 0.00472 \\
\hline & & & & & & & & & $(-1.91)$ & $(-2.59)$ & $(-1.06)$ & $(0.33)$ \\
\hline \multirow[t]{2}{*}{ Number of competing bids } & $0.225^{* * *}$ & $0.307^{* * *}$ & 0.118 & 0.127 & $0.219 * * *$ & $0.305^{* * *}$ & $0.136^{*}$ & 0.131 & $0.168^{* * *}$ & $0.269 * * *$ & 0.0309 & 0.0644 \\
\hline & $(6.40)$ & $(5.25)$ & $(1.84)$ & $(1.20)$ & $(6.31)$ & $(5.29)$ & $(2.36)$ & $(1.28)$ & $(5.43)$ & $(4.90)$ & $(1.55)$ & $(0.79)$ \\
\hline \multirow[t]{2}{*}{ Cash } & 0.00567 & 0 & 0 & 0 & 0.00998 & 0 & 0 & 0 & $0.0740 * * *$ & 0 & 0 & 0 \\
\hline & $(0.25)$ & (.) & (.) & (.) & $(0.44)$ & (.) & (.) & (.) & $(3.71)$ & (.) & (.) & (.) \\
\hline \multirow[t]{2}{*}{ Stock } & 0.0242 & 0 & 0 & 0 & $0.0393^{*}$ & 0 & 0 & 0 & $0.0903^{* * *}$ & 0 & 0 & 0 \\
\hline & $(1.28)$ & (.) & (.) & (.) & (2.09) & (.) & (.) & (.) & $(5.37)$ & (.) & (.) & (.) \\
\hline \multirow[t]{2}{*}{ Tender offer } & $0.148 * * *$ & $0.100 * * *$ & $0.226^{*}$ & $0.215^{*}$ & $0.134 * * *$ & $0.0968^{* * *}$ & 0.190 & $0.219^{*}$ & $0.0930 * * *$ & $0.0766^{* * *}$ & -0.0717 & $0.195 * *$ \\
\hline & (7.18) & (5.17) & $(2.10)$ & $(2.21)$ & $(6.41)$ & $(4.82)$ & $(1.66)$ & $(2.32)$ & $(4.42)$ & $(3.82)$ & $(-0.74)$ & $(2.72)$ \\
\hline \multirow[t]{2}{*}{ Merger of equal } & $-0.286 * * *$ & 0 & $-0.306 * * *$ & -0.0940 & $-0.288 * * *$ & 0 & $-0.325 * * *$ & -0.0642 & $-0.225^{* * *}$ & 0 & -0.0456 & -0.0387 \\
\hline & $(-5.84)$ & (.) & $(-5.45)$ & $(-1.54)$ & $(-5.89)$ & (.) & $(-5.81)$ & $(-1.39)$ & $(-5.91)$ & (.) & $(-1.80)$ & $(-0.94)$ \\
\hline \multirow[t]{2}{*}{ Deal size } & $0.0528^{*}$ & -0.0239 & $0.131^{* *}$ & -0.0840 & $0.0930 * * *$ & 0.0350 & $0.169 * * *$ & 0.108 & $0.723^{* * *}$ & $0.299 * * *$ & $2.603 * * *$ & 1.292 \\
\hline & $(2.38)$ & $(-0.89)$ & (3.13) & $(-1.33)$ & $(4.86)$ & (1.19) & $(4.48)$ & $(1.38)$ & $(7.20)$ & $(4.97)$ & (13.82) & (1.91) \\
\hline \multirow[t]{2}{*}{ Hostile acquisition } & 0.00146 & -0.0115 & -0.172 & 0.0989 & -0.0149 & -0.0376 & -0.203 & 0.168 & -0.0113 & -0.0348 & -0.00723 & 0.0173 \\
\hline & $(0.03)$ & $(-0.13)$ & $(-1.41)$ & $(0.91)$ & $(-0.26)$ & $(-0.41)$ & $(-1.64)$ & $(1.57)$ & $(-0.25)$ & $(-0.42)$ & $(-0.11)$ & $(0.20)$ \\
\hline \multirow[t]{2}{*}{ Number of day to effective } & 0.00000017 & -0.00003 & 0.000104 & 0.000531 & 0.00000384 & -0.0000276 & $0.000254 *$ & 0.000676 & 0.0000627 & 0.00000107 & $0.000198^{*}$ & 0.000265 \\
\hline & $(0.01)$ & $(-1.10)$ & $(0.85)$ & $(1.45)$ & $(0.13)$ & $(-1.01)$ & $(2.03)$ & $(1.80)$ & $(1.67)$ & $(0.04)$ & $(1.98)$ & $(1.10)$ \\
\hline \multirow[t]{2}{*}{ Target resistance to takeover } & 0.0619 & 0.126 & 0.0686 & $-0.440 *$ & 0.0754 & 0.143 & 0.0418 & $-0.520 * *$ & 0.0654 & 0.144 & -0.0229 & $-0.382 * *$ \\
\hline & $(0.85)$ & $(1.62)$ & $(0.59)$ & $(-2.58)$ & $(1.05)$ & $(1.82)$ & $(0.37)$ & $(-3.13)$ & $(1.12)$ & $(1.86)$ & $(-0.31)$ & $(-2.91)$ \\
\hline \multirow[t]{2}{*}{ Target business risk } & -2.885 & -0.607 & 0 & 12.62 & -1.320 & -0.311 & 0 & 8.381 & -0.992 & -0.804 & 0 & 3.239 \\
\hline & $(-0.59)$ & $(-0.29)$ & (.) & $(1.17)$ & $(-0.27)$ & $(-0.15)$ & (.) & $(0.81)$ & $(-0.22)$ & $(-0.42)$ & (.) & $(0.40)$ \\
\hline \multirow[t]{2}{*}{ Target firm size (sales) } & $-0.0714^{* *}$ & 0.0124 & $-0.158^{* * *}$ & 0.0491 & & & & & & & & \\
\hline & $(-3.07)$ & $(0.52)$ & $(-4.00)$ & $(0.88)$ & & & & & & & & \\
\hline \multirow[t]{2}{*}{ Target firm size (assets) } & & & & & $-0.126 * * *$ & $-0.0799 *$ & $-0.215^{* * *}$ & $-0.194^{*}$ & & & & \\
\hline & & & & & $(-6.35)$ & $(-2.56)$ & $(-5.77)$ & $(-2.25)$ & & & & \\
\hline
\end{tabular}




\begin{tabular}{|c|c|c|c|c|c|c|c|c|c|c|c|c|}
\hline \multirow[t]{2}{*}{ Target firm size (market value) } & & & & & & & & & $-0.735 * * *$ & $-0.327^{* * *}$ & $-2.608 * * *$ & -1.302 \\
\hline & & & & & & & & & $(-7.34)$ & $(-5.41)$ & $(-13.81)$ & $(-1.94)$ \\
\hline \multirow[t]{2}{*}{ Target market to book ratio } & $-0.000256^{*}$ & $-0.00220^{*}$ & $-0.000800^{* *}$ & 0.000202 & $-0.000278^{* *}$ & $-0.00314^{*}$ & $-0.000693^{*}$ & 0.000360 & $-0.000192 *$ & $-0.00175^{*}$ & $-0.000430 * * *$ & 0.000157 \\
\hline & $(-2.57)$ & $(-2.22)$ & $(-2.82)$ & $(1.02)$ & $(-2.84)$ & $(-2.42)$ & $(-2.35)$ & $(1.52)$ & $(-1.98)$ & $(-2.25)$ & $(-3.75)$ & (1.23) \\
\hline \multirow[t]{2}{*}{ Target ROA } & $0.000873^{*}$ & 0.0000263 & $0.00191 *$ & 0.0000782 & $0.00112^{* *}$ & -0.0000795 & $0.00372^{* * *}$ & -0.00260 & 0.000534 & 0.000132 & -0.000373 & -0.00152 \\
\hline & (2.21) & $(0.05)$ & $(1.97)$ & $(0.02)$ & (2.75) & $(-0.15)$ & (3.41) & $(-0.50)$ & $(1.30)$ & $(0.31)$ & $(-0.81)$ & $(-0.44)$ \\
\hline \multirow[t]{2}{*}{ Target ROE } & 0.00000832 & -0.0000137 & 0.000170 & 0.000102 & 0.00000483 & -0.0000201 & -0.0000216 & 0.000466 & 0.00000118 & -0.0000125 & -0.0000549 & 0.000305 \\
\hline & $(0.29)$ & $(-0.68)$ & $(0.86)$ & $(0.19)$ & $(0.16)$ & $(-1.75)$ & $(-0.10)$ & $(0.81)$ & $(0.04)$ & $(-0.63)$ & $(-0.72)$ & $(0.81)$ \\
\hline \multirow[t]{2}{*}{ Target operating cashflow } & -0.000520 & -0.00857 & 0.000162 & -0.0190 & -0.000283 & -0.00639 & $0.000824 * * *$ & $-0.0241 *$ & -0.000282 & -0.00645 & $0.000369 * * *$ & $-0.0158^{*}$ \\
\hline & $(-0.41)$ & $(-1.28)$ & $(0.79)$ & $(-1.78)$ & $(-0.21)$ & $(-0.99)$ & $(7.28)$ & $(-2.34)$ & $(-0.23)$ & $(-1.08)$ & $(5.67)$ & $(-2.18)$ \\
\hline \multirow[t]{2}{*}{ Target financial independence } & 0.00246 & -0.0423 & -0.108 & -0.0928 & 0.0173 & -0.0175 & -0.0772 & -0.0314 & -0.0153 & -0.0279 & -0.0417 & -0.0323 \\
\hline & $(0.04)$ & $(-0.75)$ & $(-1.28)$ & $(-0.60)$ & $(0.33)$ & $(-0.33)$ & $(-0.88)$ & $(-0.20)$ & $(-0.33)$ & $(-0.53)$ & $(-1.18)$ & $(-0.30)$ \\
\hline \multirow[t]{2}{*}{ Target debt to equity } & -0.00000720 & $0.00298^{*}$ & -0.00134 & $-0.00625 * *$ & 0.000373 & $0.00502^{* *}$ & 0.00123 & -0.00177 & 0.000112 & $0.00301 *$ & 0.000330 & -0.00120 \\
\hline & $(-0.03)$ & $(1.99)$ & $(-0.85)$ & $(-2.80)$ & $(1.16)$ & $(3.21)$ & $(0.77)$ & $(-0.63)$ & $(0.42)$ & $(2.05)$ & $(0.55)$ & $(-0.54)$ \\
\hline \multirow[t]{2}{*}{ Public bidder } & 0.109 & 0.0926 & 0.105 & 0.227 & $0.134^{*}$ & 0.0806 & 0.114 & $0.378^{* *}$ & 0.107 & 0.0930 & 0.0237 & $0.466^{* * *}$ \\
\hline & $(1.62)$ & $(0.66)$ & $(1.48)$ & $(1.94)$ & $(2.12)$ & $(0.59)$ & $(1.54)$ & (3.01) & $(1.90)$ & $(0.78)$ & $(0.27)$ & $(3.56)$ \\
\hline \multirow[t]{2}{*}{$\begin{array}{l}\text { Target shares owned by bidder } \\
\text { before M\&A }\end{array}$} & -0.0580 & -0.0594 & -0.0657 & $-0.304^{*}$ & 0.000559 & 0.00938 & -0.00946 & -0.207 & $0.530 * * *$ & $0.215^{*}$ & $2.224 * * *$ & 0.975 \\
\hline & $(-0.84)$ & $(-0.62)$ & $(-0.57)$ & $(-2.17)$ & $(0.01)$ & $(0.10)$ & $(-0.08)$ & $(-1.44)$ & $(5.05)$ & $(2.15)$ & $(9.21)$ & $(1.50)$ \\
\hline \multirow[t]{2}{*}{$\begin{array}{l}\text { Target shares owned by bidder } \\
\text { after M\&A }\end{array}$} & $0.260 * * *$ & $0.352^{* * *}$ & -0.122 & -0.167 & $0.219 * * *$ & $0.277^{* * *}$ & -0.116 & -0.191 & $-0.594 * * *$ & -0.0536 & $-3.035^{* * *}$ & -0.185 \\
\hline & $(6.78)$ & $(8.91)$ & $(-0.70)$ & $(-0.89)$ & (6.99) & $(6.42)$ & $(-0.66)$ & $(-1.05)$ & $(-4.18)$ & $(-0.64)$ & $(-9.64)$ & $(-1.33)$ \\
\hline \multirow[t]{2}{*}{$\begin{array}{l}\text { Target total volatility * Target R\&D } \\
\text { to market value }\end{array}$} & 19.81 & $36.57^{* *}$ & -6.546 & 33.96 & $23.52^{*}$ & $35.18^{* *}$ & 2.265 & 36.64 & $20.48^{*}$ & $35.92^{* *}$ & 1.447 & 30.03 \\
\hline & $(1.87)$ & $(2.89)$ & $(-0.47)$ & $(0.75)$ & $(2.25)$ & $(2.72)$ & $(0.16)$ & $(0.87)$ & $(2.13)$ & $(2.90)$ & (0.19) & $(1.10)$ \\
\hline \multirow[t]{2}{*}{$\begin{array}{l}\text { Target total volatility * Target R\&D } \\
\text { to sales }\end{array}$} & -0.653 & -0.292 & 1.277 & -12.31 & -0.658 & -0.188 & 0.405 & -13.60 & -0.687 & -0.291 & 0.0775 & -9.653 \\
\hline & $(-1.20)$ & $(-0.93)$ & $(1.43)$ & $(-1.59)$ & $(-1.10)$ & $(-0.60)$ & $(0.47)$ & $(-1.85)$ & $(-1.18)$ & $(-0.98)$ & $(0.20)$ & $(-1.90)$ \\
\hline \multirow[t]{2}{*}{$\begin{array}{l}\text { Target total volatility * Target R\&D } \\
\text { growth }\end{array}$} & 0.364 & -0.0184 & 0.790 & -6.668 & 0.519 & -0.229 & 0.912 & -8.936 & 0.151 & -0.447 & 0.501 & -5.133 \\
\hline & $(0.90)$ & $(-0.01)$ & $(0.58)$ & $(-0.75)$ & $(1.26)$ & $(-0.18)$ & $(0.63)$ & $(-1.03)$ & $(0.42)$ & $(-0.34)$ & $(0.77)$ & $(-0.91)$ \\
\hline \multirow[t]{2}{*}{$\begin{array}{l}\text { Target total volatility * Target } \\
\text { organizational flexibility }\end{array}$} & -0.278 & -3.956 & $-2.026^{*}$ & -4.556 & -0.438 & -3.242 & -1.145 & -0.493 & -0.121 & -3.795 & -0.597 & -2.914 \\
\hline & $(-0.49)$ & $(-1.79)$ & $(-1.97)$ & $(-0.40)$ & $(-0.78)$ & $(-1.46)$ & $(-1.09)$ & $(-0.04)$ & $(-0.23)$ & $(-1.83)$ & $(-1.22)$ & $(-0.39)$ \\
\hline \multirow[t]{2}{*}{$\begin{array}{l}\text { Target total volatility* Target } \\
\text { financial flexibility (leverage) }\end{array}$} & 0 & 0 & -2.336 & 0 & 0 & 0 & -6.324 & 0 & 0 & 0 & $-2.957^{*}$ & 0 \\
\hline & (.) & $()$. & $(-0.68)$ & (.) & (.) & (.) & $(-1.92)$ & (.) & (.) & (.) & $(-1.99)$ & (.) \\
\hline
\end{tabular}




\begin{tabular}{|c|c|c|c|c|c|c|c|c|c|c|c|c|}
\hline $\begin{array}{l}\text { Target total volatility * Target } \\
\text { financial flexibility (cashflow } \\
\text { coverage) }\end{array}$ & 0.313 & 0.293 & 0.477 & 0.813 & 0.434 & 0.210 & 0.870 & 1.830 & -0.321 & -0.261 & -0.437 & -0.945 \\
\hline & $(0.37)$ & $(0.19)$ & $(0.37)$ & $(0.16)$ & $(0.51)$ & $(0.14)$ & $(0.79)$ & $(0.39)$ & $(-0.41)$ & $(-0.17)$ & $(-1.04)$ & $(-0.31)$ \\
\hline \multirow[t]{2}{*}{$\begin{array}{l}\text { Target total volatility * Target sales } \\
\text { growth }\end{array}$} & $0.0130 *$ & -1.017 & -0.155 & 2.974 & 0.00689 & -0.949 & -0.0627 & 3.388 & $0.0191 * *$ & -0.467 & -0.0936 & 1.572 \\
\hline & $(2.29)$ & $(-0.59)$ & $(-0.30)$ & $(1.36)$ & $(1.06)$ & $(-0.55)$ & $(-0.11)$ & $(1.62)$ & $(2.97)$ & $(-0.29)$ & $(-0.40)$ & (1.11) \\
\hline \multirow[t]{2}{*}{$\begin{array}{l}\text { Bidder total volatility * Bidder R\&D } \\
\text { to market value }\end{array}$} & 0.182 & 0.613 & 0.473 & -1.874 & 0.106 & 0.712 & 0.674 & -1.338 & 0.0214 & 0.169 & 0.286 & -0.852 \\
\hline & $(0.36)$ & $(0.24)$ & $(0.64)$ & $(-1.45)$ & $(0.21)$ & $(0.29)$ & $(0.96)$ & $(-1.05)$ & $(0.05)$ & $(0.07)$ & $(1.02)$ & $(-0.89)$ \\
\hline \multirow[t]{2}{*}{$\begin{array}{l}\text { Bidder total volatility * Bidder R\&D } \\
\text { to sales }\end{array}$} & -0.814 & -3.845 & -2.486 & 46.44 & -1.356 & -3.863 & -2.599 & 56.76 & -0.468 & -3.325 & -0.826 & 24.95 \\
\hline & $(-0.52)$ & $(-1.64)$ & $(-0.73)$ & $(0.94)$ & $(-0.93)$ & $(-1.69)$ & $(-0.79)$ & $(1.14)$ & $(-0.33)$ & $(-1.45)$ & $(-0.60)$ & $(0.63)$ \\
\hline \multirow[t]{2}{*}{$\begin{array}{l}\text { Bidder total volatility * Bidder R\&D } \\
\text { growth }\end{array}$} & -0.238 & -0.0321 & 0.394 & -2.202 & -0.389 & 0.0579 & 0.343 & -3.402 & -0.258 & -0.119 & 0.168 & -2.171 \\
\hline & $(-0.44)$ & $(-0.03)$ & $(0.25)$ & $(-0.26)$ & $(-0.73)$ & $(0.05)$ & $(0.22)$ & $(-0.45)$ & $(-0.52)$ & $(-0.12)$ & $(0.28)$ & $(-0.29)$ \\
\hline \multirow[t]{2}{*}{ _cons } & -0.110 & -0.287 & 0.115 & 0.0374 & -0.0945 & -0.123 & 0.0767 & 0.114 & $0.622^{* * *}$ & 0.141 & $2.915 * * *$ & -0.313 \\
\hline & $(-0.85)$ & $(-1.76)$ & $(0.53)$ & $(0.14)$ & $(-0.80)$ & $(-0.71)$ & $(0.35)$ & $(0.43)$ & $(3.62)$ & $(0.87)$ & (9.27) & $(-1.38)$ \\
\hline $\mathbf{N}$ & 2559 & 1029 & 741 & 275 & 2559 & 1029 & 741 & 275 & 2559 & 1029 & 741 & 275 \\
\hline adj.R-sq & 0.264 & 0.517 & 0.11 & 0.296 & 0.273 & 0.521 & 0.135 & 0.326 & 0.387 & 0.547 & 0.763 & 0.531 \\
\hline
\end{tabular}




\section{LIST OF REFERENCES}

Antoniou, A., Arbour, P., \& Zhao, H. (2008). How Much Is Too Much: Are Merger Premiums Too High? European Financial Management, 14(2), 268-287. doi:10.1111/j.1468036X.2007.00404.X

Bange, M. M. (2004). Board Composition, Board Effectiveness, and the Observed Form of Takeover Bids. The Review of Financial Studies, 17(4), 1185-1215. doi:10.1093/rfs/hhh001

Baron, D. P. (1983). Tender Offers and Management Resistance. The Journal of Finance, 38(2), 331-343. doi:10.2307/2327964

Bauguess, S. W., Moeller, S. B., Schlingemann, F. P., \& Zutter, C. J. (2009). Ownership structure and target returns. Journal of Corporate Finance, 15(1), 48-65. doi:https://doi.org/10.1016/j.jcorpfin.2008.09.002

Betton, S., \& Eckbo, B. E. (2000). Toeholds, Bid Jumps, and Expected Payoffs in Takeovers. The Review of Financial Studies, 13(4), 841-882.

Bhagat, S., Brickley, J. A., \& Loewenstein, U. R. I. (1987). The Pricing Effects of Interfirm Cash Tender Offers. The Journal of Finance, 42(4), 965-986. doi:10.1111/j.15406261.1987.tb03922.x

Bradley, M., Desai, A., \& Kim, E. H. (1983). The rationale behind interfirm tender offers. Journal of Financial Economics, 11(1), 183-206. doi:http://dx.doi.org/10.1016/0304405X(83)90010-7

Bris, A. (2001). Toeholds, Takeover Premium,and the Probability of Being Acquired. Journal of Corporate Finance(8), 227-253.

Bulow, J., Huang, M., \& Klemperer, P. (1999). Toeholds and Takeovers. Journal of Political Economy, 107(3), 427-454. doi:10.1086/250068

Burkart, M. (1995). Initial Shareholdings and Overbidding in Takeover Contests. The Journal of Finance, $L(5)$.

Chan, L. K. C., Lakonishok, J., \& Sougiannis, T. (2001). The Stock Market Valuation of Research and Development Expenditures. The Journal of Finance, 56(6), 2431-2456. doi:10.1111/0022-1082.00411

Chatterjee, S., John, K., \& Yan, A. (2012). Takeovers and Divergence of Investor Opinion. The Review of Financial Studies, 25(1), 227-277.

Díaz, B. D., Azofra, S. S., \& Gutiérrez, C. L. (2009). Are M\&A Premiums Too High? Analysis of a Quadratic Relationship between Premiums and Returns. Quarterly Journal of Finance and Accounting, 48(3).

Franks, J. R., \& Harris, R. S. (1989). Shareholder wealth effects of corporate takeovers. Journal of Financial Economics, 23(2), 225-249.

Giliberto, S. M., \& Varaiya, N. P. (1989). The Winner's Curse and Bidder Competition in Acquisitions: Evidence from Failed Bank Auctions. The Journal of Finance, 44(1), 5975. doi:10.1111/j.1540-6261.1989.tb02404.x

Greenfield, L. (1992). Bidders still have deep pockets despite the recession. Acquisitions Monthly. Acquisitions Monthly, 8.

Grullon, G., Lyandres, E., \& Zhdanov, A. (2012). Real Options, Volatility, and Stock Returns. The Journal of Finance, 67(4), 1499-1537. doi:10.1111/j.1540-6261.2012.01754.x 
Haunschild, P. R. (1994). How Much is That Company Worth?: Interorganizational Relationships, Uncertainty, and Acquisition Premiums. Administrative Science Quarterly, 39(3), 391-411. doi:10.2307/2393296

Hayward, M. L. A., \& Hambrick, D. C. (1997). Explaining the Premiums Paid for Large Acquisitions: Evidence of CEO Hubris. Administrative Science Quarterly, 42(1). doi: $10.2307 / 2393810$

Jahera, J. S., Hand, J., \& Lloyd, W. P. (1985). An Empirical Inquiry into the Premiums for Controlling Interests. Quarterly Journal of Business and Economics, 24(3), 67-77.

Jindra, J., \& Moeller, T. (2015). TARGET FINANCIAL INDEPENDENCE AND TAKEOVER PRICING. Journal of Financial Research, 38(3), 379-413. doi:10.1111/jfir.12064

Kumar, M. V. S., Dixit, J., \& Francis, B. (2015). The impact of prior stock market reactions on risk taking in acquisitions. Strategic Management Journal, 36(13), 2111-2121. doi:10.1002/smj.2349

Laamanen, T. (2007). On the role of acquisition premium in acquisition research. Strategic Management Journal(28), 1359-1369. doi:10.1002/smj.639

Lambrecht, B. M. (2004). The timing and terms of mergers motivated by economies of scale. Journal of Financial Economics, 72(1), 41-62. doi:http://dx.doi.org/10.1016/j.jfineco.2003.09.002

Malatesta, P. H., \& Walkling, R. A. (1988). Poison pill securities. Journal of Financial Economics, 20, 347-376.

Moeller, T. (2005). Let's make a deal! How shareholder control impacts merger payoffs. Journal of Financial Economics, 76(1), 167-190. doi:http://dx.doi.org/10.1016/j.jfineco.2004.11.001

Niden, C. (1988). The role of taxes in corporate acquisitions: Effects on premium and type of consideration. University of Chicago,

Robinson, J. R., \& Shane, P. B. (1990). Acquisition Accounting Method and Bid Premia for Target Firms. The Accounting Review, 65(1), 25-48.

Roll, R. (1986). The Hubris Hypothesis of Corporate Takeovers. The Journal of Business, 59(2), 197-216.

Schwert, G. W. (2000). Hostility in Takeovers: In the Eyes of the Beholder? The Journal of Finance, 55(6), 2599-2640. doi:10.1111/0022-1082.00301

Schwert, G. W. (2003). Chapter 15 Anomalies and market efficiency. In Handbook of the Economics of Finance (Vol. Volume 1, Part B, pp. 939-974): Elsevier.

Servaes, H. (1991). Tobin's Q and the Gains from Takeovers. The Journal of Finance, 46(1), 409-419. doi:10.2307/2328702

Shelton, L. M. (2000). Merger market dynamics: insights into the behavior of target and bidder firms. Journal of Economic Behavior \& Organization, 41(4), 363-383. doi:http://dx.doi.org/10.1016/S0167-2681(99)00081-5

Shleifer, A., \& Vishny, R. W. (1997). A Survey of Corporate Governance. The Journal of Finance, 52(2), 737-783. doi:10.1111/j.1540-6261.1997.tb04820.x

Singh, R. (1998). Takeover Bidding with Toeholds: The Case of the Owner's Curse. The Review of Financial Studies, 11(4), 679-704.

Sinha, S. (1992). Management Resistance to Takeover Bids and Shareholder Response. Financial Review, 27(3), 375-390. doi:10.1111/j.1540-6288.1992.tb01323.x 
Sirower, M. L. (1997). The Synergy Trap: How Companies Lose the Acquisition Game: New York: The Free Press.

Slusky, A. R., \& Caves, R. E. (1991). Synergy, Agency, and the Determinants of Premia Paid in Mergers. The Journal of Industrial Economics, 39(3), 277-296. doi:10.2307/2098520

Smit, H. T., \& Trigeorgis, L. (2012). Strategic investment: Real options and games: Princeton University Press.

Sonenshine, R. (2010). The Stock Market's Valuation of R\&D and Market Concentration in Horizontal Mergers. Review of Industrial Organization, 37(2), 119-140. doi:10.1007/s11151-010-9262-8

Sudarsanam, S., \& Sorwar, G. (2010). Determinants of Takeover Premium in Cash Offers: An Option Pricing Approach. Journal of Business Finance \& Accounting, 37(5), 687-714. doi:10.1111/j.1468-5957.2010.02190.x

Travlos, N. G. (1987). Corporate Takeover Bids, Methods of Payment, and Bidding Firms' Stock Returns. The Journal of Finance, 42(4), 943-963. doi:10.1111/j.15406261.1987.tb03921.x

Trigeorgis, L. (1996). Real options: Managerial flexibility and strategy in resource allocation: MIT press.

Trigeorgis, L., \& Lambertides, N. (2014). The Role of Growth Options in Explaining Stock Returns. Journal of Financial and Quantitative Analysis, 49(3), 749-771. doi:10.1017/S0022109014000118

Varaiya, N. P. (1988). The 'winner's curse' hypothesis and corporate takeovers. Managerial and Decision Economics, 9(3), 209-219. doi:10.1002/mde.4090090306

Varaiya, N. P., \& Ferris, K. R. (1987). Overpaying in Corporate Takeovers: The Winner's Curse Financial Analysts Journal, 43(3), 64-70. doi:http://dx.doi.org/10.2469/faj.v43.n3.64

Walkling, R. A., \& Edmister, R. O. (1985). Determinants of Tender Offer Premiums. Financial Analysts Journal, 41(1), 27-37.

Zhu, P., Jog, V., \& Otchere, I. (2014). Idiosyncratic volatility and mergers and acquisitions in emerging markets. Emerging Markets Review, 19, 18-48.

doi:http://dx.doi.org/10.1016/j.ememar.2014.04.001 